\title{
Blue LED mediated in situ generation of pyridinium and isoquinolinium ylides from aryl diazoesters: Their application in the synthesis of diverse dihydroindolizine
}

\author{
Saibal Sar, ${ }^{\S}$ Souvik Guha, ${ }^{\S}$ Tejas Prabakar, ${ }^{\S}$ Debajit Maiti and Subhabrata Sen* \\ Department of Chemistry, School of Natural Sciences, Shiv Nadar University \\ Dadri, Chithera, Gautam Buddha Nagar, \\ Uttar Pradesh 201314, India \\ subhabrata.sen@snu.edu.in
}

\begin{tabular}{|c|c|c|}
\hline Entry & Content & Page Numbers \\
\hline 1 & Structure of aryl diazo esters & S2 \\
\hline 2 & Computational details & S3 - S6 \\
\hline 3 & ${ }^{1} \mathrm{H}$ and ${ }^{13}$ C NMRs & S7 - S50 \\
\hline
\end{tabular}


Substituted aryl diazo esters:<smiles>COC(=O)C(=N)c1ccccc1</smiles>

$3 a$<smiles>COC(=O)C(=N)c1ccc(F)cc1</smiles><smiles>COC(=O)C(=N)c1cccc(Cl)c1</smiles>

$3 i$<smiles>COC(=O)C(=N)c1ccsc1</smiles><smiles>COC(=O)c1ccc(C(C)(C)C)cc1</smiles><smiles>COC(=O)C(=N)c1ccc(Cl)cc1</smiles><smiles>CCOC(=O)C(=N)c1ccsc1</smiles>

3j<smiles>COC(=O)c1cccc([N+](=O)[O-])c1</smiles><smiles>CCOC(=O)c1ccc(C)cc1</smiles><smiles>COC(=O)c1ccc(Br)cc1</smiles><smiles>COC(=O)C(=N)c1cccc(F)c1</smiles><smiles>COC(=O)c1cccc(OC)c1</smiles><smiles>COC(=O)c1cccc(Br)c1</smiles>

3k<smiles>COC(=O)C(=N)c1ccc(OC)cc1</smiles><smiles>CCOC(=O)C=[W]</smiles> 


\section{Computational Details:}<smiles></smiles>

$R-9 \mathrm{c}$<smiles>CCOC(=O)C1=C2C=CC=CN2[C@@]2(c3ccc(C)cc3)C(=O)N(C(C)(C)C)c3ccccc3[C@]12OCC</smiles>

$S-9 c$

Figure S1. Potential diastereomers of compound 9c

The chemical structure of the compound 9c (2D structure) is shown above. Both the $R$ - and $S$ diastereomers were converted into their 3D forms using Gaussview $5^{\mathrm{TM}}$. The structural properties of both the isomers were calculated by the Density Functional Theory (DFT) method using Gaussian $09^{\text {тм }}$. The structures were optimized for ground state closed shell system. B3LYP/6-31 G (d) was used in all calculations. Frequency calculations were performed the optimization level of basis set to confirm the nature of stationary points, and to obtain zero-point corrections and the Gibbs free energies.

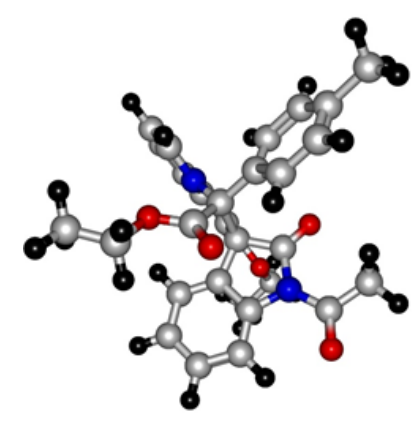

9c ( $R$-isomer)

Energy $=-1079906.644884 \mathrm{kcal} / \mathrm{mol}$

Energy Difference $=1.611131 \mathrm{kcal} / \mathrm{mol}$

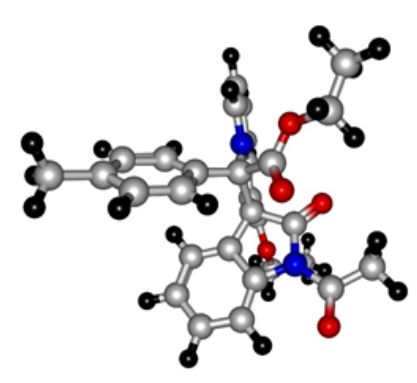

9c (S-isomer)

Energy $=-1079908.256015 \mathrm{kcal} / \mathrm{mol}$

Figure S2: The optimized 3D-structure of 9c ( $R$-isomer) and 9c ( $S$-isomer).

The DFT calculation for both the diastereomers show that $S$-isomer is energetically more stable than $\boldsymbol{R}$-isomer by $1.6 \mathrm{kcal} / \mathrm{mol}$. Due to this difference in the stability of both structure it is expected that $\boldsymbol{S}$-isomer is more feasible relative to the $\boldsymbol{R}$-isomer. 


\section{Optimized geometries:}

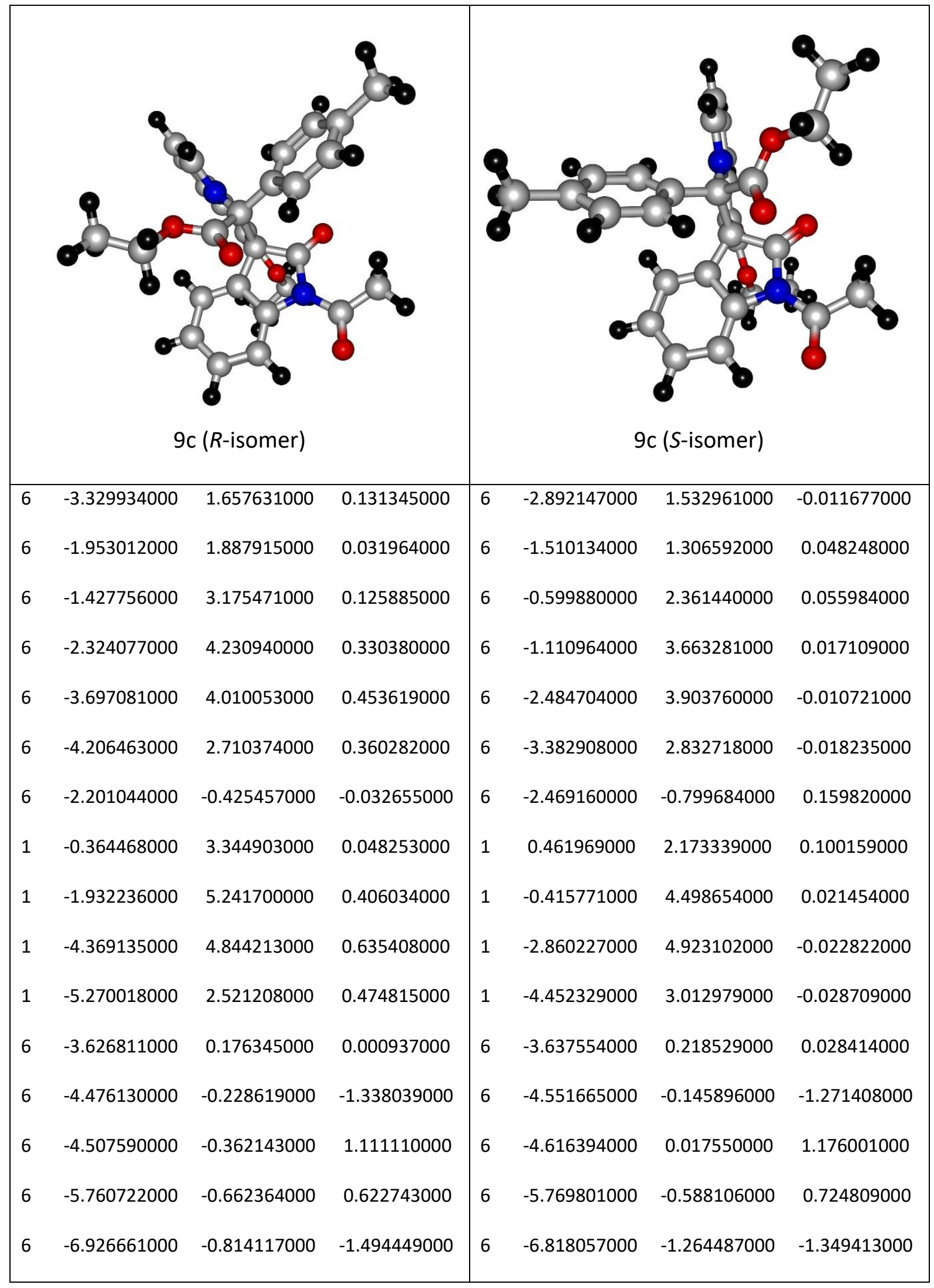




\begin{tabular}{|c|c|c|c|c|c|c|c|}
\hline 6 & -6.961220000 & -1.088452000 & 1.280916000 & 6 & -6.932033000 & -1.048680000 & 1.426940000 \\
\hline 6 & -8.078032000 & -1.212770000 & -0.880254000 & 6 & -7.929997000 & -1.705193000 & -0.693212000 \\
\hline 6 & -8.081840000 & -1.347070000 & 0.542723000 & 6 & -7.972159000 & -1.595890000 & 0.730587000 \\
\hline 1 & -6.921354000 & -1.196096000 & 2.356865000 & 1 & -6.934856000 & -0.931239000 & 2.502312000 \\
\hline 1 & -8.959120000 & -1.429802000 & -1.471748000 & 1 & -8.757227000 & -2.122623000 & -1.254355000 \\
\hline 1 & -8.990990000 & -1.668650000 & 1.043528000 & 1 & -8.850509000 & -1.946576000 & 1.265664000 \\
\hline 6 & 0.125483000 & 0.510264000 & -0.286355000 & 6 & 0.038278000 & -0.673948000 & 0.204850000 \\
\hline 8 & 0.835929000 & 1.500057000 & -0.290455000 & 8 & 1.028063000 & 0.035416000 & 0.182153000 \\
\hline 6 & 0.693065000 & -0.879092000 & -0.467537000 & 6 & 0.141581000 & -2.179659000 & 0.289258000 \\
\hline 1 & 0.534764000 & -1.490236000 & 0.424745000 & 1 & -0.367852000 & -2.570271000 & 1.173639000 \\
\hline 1 & 0.210693000 & -1.409386000 & -1.292909000 & 1 & -0.328494000 & -2.656422000 & -0.574939000 \\
\hline 1 & 1.760554000 & -0.759384000 & -0.660342000 & 1 & 1.205572000 & -2.419851000 & 0.323521000 \\
\hline 6 & -4.144970000 & -0.417888000 & 2.504632000 & 6 & -4.323384000 & 0.213175000 & 2.575394000 \\
\hline 8 & -4.867554000 & -0.784134000 & 3.426375000 & 8 & -5.115754000 & 0.082141000 & 3.503782000 \\
\hline 8 & -2.852893000 & -0.008111000 & 2.698511000 & 8 & -3.015702000 & 0.563505000 & 2.772741000 \\
\hline 8 & -1.922414000 & -1.599359000 & 0.016631000 & 8 & -2.609039000 & -2.001076000 & 0.259864000 \\
\hline 7 & -1.272483000 & 0.642769000 & -0.126963000 & 7 & -1.251146000 & -0.097320000 & 0.145309000 \\
\hline 7 & -5.814590000 & -0.519733000 & -0.760771000 & 7 & -5.759205000 & -0.750246000 & -0.656080000 \\
\hline 1 & -6.830209000 & -0.706159000 & -2.566274000 & 1 & -6.709396000 & -1.300448000 & -2.423742000 \\
\hline 6 & -3.969323000 & -1.489498000 & -2.076411000 & 6 & -4.961807000 & 1.083047000 & -2.111667000 \\
\hline 6 & -3.065693000 & -1.434271000 & -3.146220000 & 6 & -4.138153000 & 1.599634000 & -3.122799000 \\
\hline 6 & -4.393562000 & -2.756500000 & -1.644417000 & 6 & -6.166387000 & 1.749852000 & -1.843829000 \\
\hline 6 & -2.626919000 & -2.603463000 & -3.769583000 & 6 & -4.520983000 & 2.726590000 & -3.846973000 \\
\hline 1 & -2.695473000 & -0.480222000 & -3.496991000 & 1 & -3.187326000 & 1.129492000 & -3.340207000 \\
\hline 6 & -3.948037000 & -3.915641000 & -2.270693000 & 6 & -6.538121000 & 2.880099000 & -2.571060000 \\
\hline 1 & -5.066993000 & -2.851025000 & -0.800655000 & 1 & -6.824300000 & 1.401490000 & -1.055588000 \\
\hline 6 & -3.059002000 & -3.864890000 & -3.351677000 & 6 & -5.728399000 & 3.387850000 & -3.592631000 \\
\hline
\end{tabular}




\begin{tabular}{|c|c|c|c|c|c|c|c|}
\hline 1 & -1.930820000 & -2.524172000 & -4.601686000 & 1 & -3.858172000 & 3.101152000 & -4.623782000 \\
\hline 1 & -4.294302000 & -4.879411000 & -1.904131000 & 1 & -7.477781000 & 3.373941000 & -2.334190000 \\
\hline 6 & -2.599024000 & -5.126487000 & -4.042229000 & 6 & -6.147654000 & 4.591003000 & -4.402914000 \\
\hline 1 & -2.344561000 & -5.908396000 & -3.317699000 & 1 & -5.285528000 & 5.207569000 & -4.679144000 \\
\hline 1 & -3.384144000 & -5.533757000 & -4.693112000 & 1 & -6.641294000 & 4.288451000 & -5.336160000 \\
\hline 1 & -1.718088000 & -4.943216000 & -4.665534000 & 1 & -6.852980000 & 5.220614000 & -3.850713000 \\
\hline 6 & -4.496997000 & 1.001897000 & -2.270382000 & 6 & -3.780476000 & -1.144913000 & -2.166022000 \\
\hline 8 & -3.515287000 & 1.401003000 & -2.857021000 & 8 & -2.664173000 & -0.905976000 & -2.578473000 \\
\hline 8 & -5.695159000 & 1.600734000 & -2.333290000 & 8 & -4.458744000 & -2.258255000 & -2.450271000 \\
\hline 6 & -5.746168000 & 2.822393000 & -3.121268000 & 6 & -3.741525000 & -3.257820000 & -3.225921000 \\
\hline 6 & -7.174721000 & 3.328018000 & -3.081538000 & 6 & -4.663506000 & -4.449142000 & -3.392407000 \\
\hline 1 & -5.412347000 & 2.593653000 & -4.137480000 & 1 & -2.828652000 & -3.511729000 & -2.680551000 \\
\hline 1 & -5.039258000 & 3.533579000 & -2.684737000 & 1 & -3.454047000 & -2.813157000 & -4.183268000 \\
\hline 1 & -7.251562000 & 4.254399000 & -3.660852000 & 1 & -4.150537000 & -5.232484000 & -3.960724000 \\
\hline 1 & -7.865360000 & 2.595801000 & -3.512008000 & 1 & -4.949543000 & -4.859436000 & -2.419233000 \\
\hline 1 & -7.488780000 & 3.537348000 & -2.054232000 & 1 & -5.573293000 & -4.172733000 & -3.935229000 \\
\hline 6 & -2.369724000 & -0.015368000 & 4.056462000 & 6 & -2.610482000 & 0.804754000 & 4.134708000 \\
\hline 6 & -2.720628000 & 1.278308000 & 4.777978000 & 6 & -2.217819000 & -0.486606000 & 4.838905000 \\
\hline 1 & -1.287197000 & -0.137288000 & 3.961164000 & 1 & -3.426004000 & 1.305151000 & 4.662955000 \\
\hline 1 & -2.787255000 & -0.881456000 & 4.575681000 & 1 & -1.760640000 & 1.487394000 & 4.049213000 \\
\hline 1 & -2.274125000 & 1.282247000 & 5.779499000 & 1 & -1.846230000 & -0.266315000 & 5.846796000 \\
\hline 1 & -2.341533000 & 2.145155000 & 4.226758000 & 1 & -3.082585000 & -1.149904000 & 4.925990000 \\
\hline 1 & -3.805078000 & 1.372605000 & 4.883525000 & 1 & -1.426752000 & -1.006006000 & 4.287389000 \\
\hline
\end{tabular}


${ }^{1} \mathrm{H}(400 \mathrm{MHz})$ and ${ }^{13} \mathrm{C}\left\{{ }^{1} \mathrm{H}\right\}(100 \mathrm{MHz}) \mathrm{NMR}$ of $7 \mathrm{a}$ in $\mathrm{CDCl}_{3}$ :

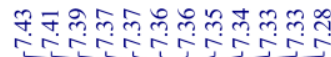

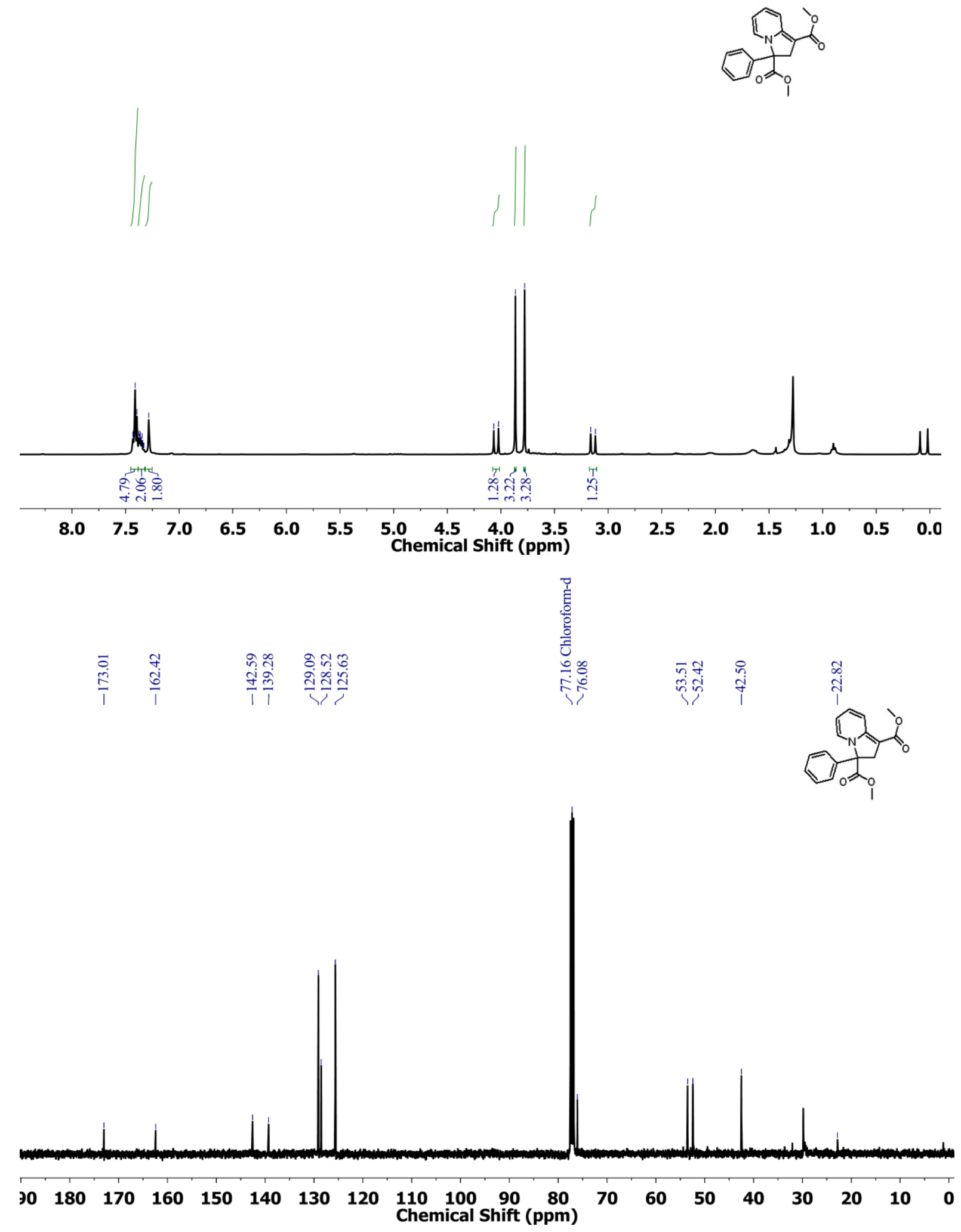


${ }^{1} \mathrm{H}(400 \mathrm{MHz})$ and ${ }^{13} \mathrm{C}\left\{{ }^{1} \mathrm{H}\right\}(100 \mathrm{MHz})$ NMR of $7 \mathbf{b}$ in $\mathrm{CDCl}_{3}$ :

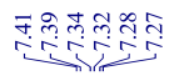

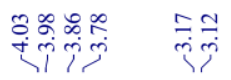

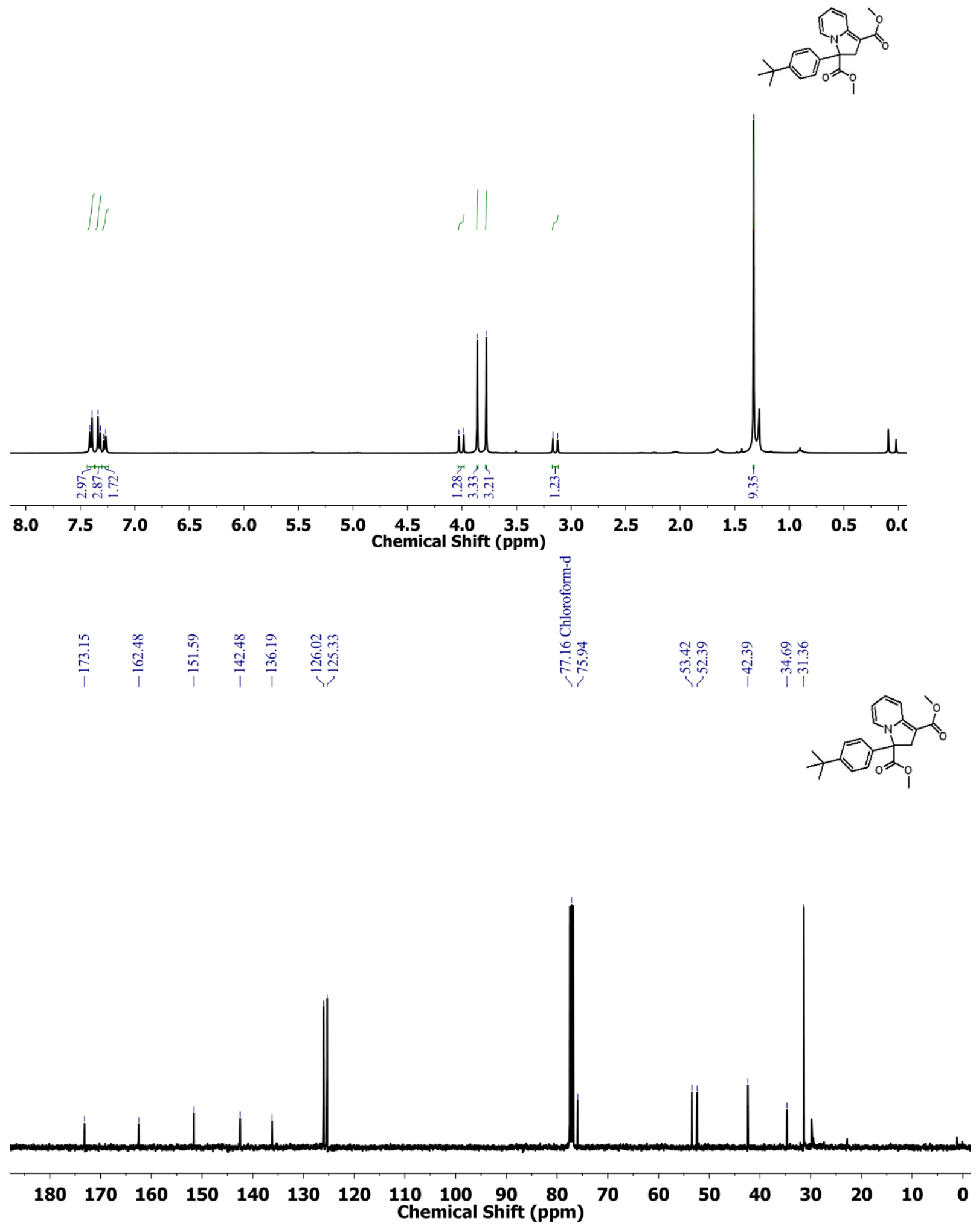


${ }^{1} \mathrm{H}(400 \mathrm{MHz})$ and ${ }^{13} \mathrm{C}\left\{{ }^{1} \mathrm{H}\right\}(100 \mathrm{MHz}) \mathrm{NMR}$ of $7 \mathrm{c}$ in $\mathrm{CDCl}_{3}:$

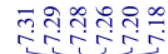

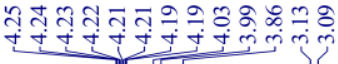

1)
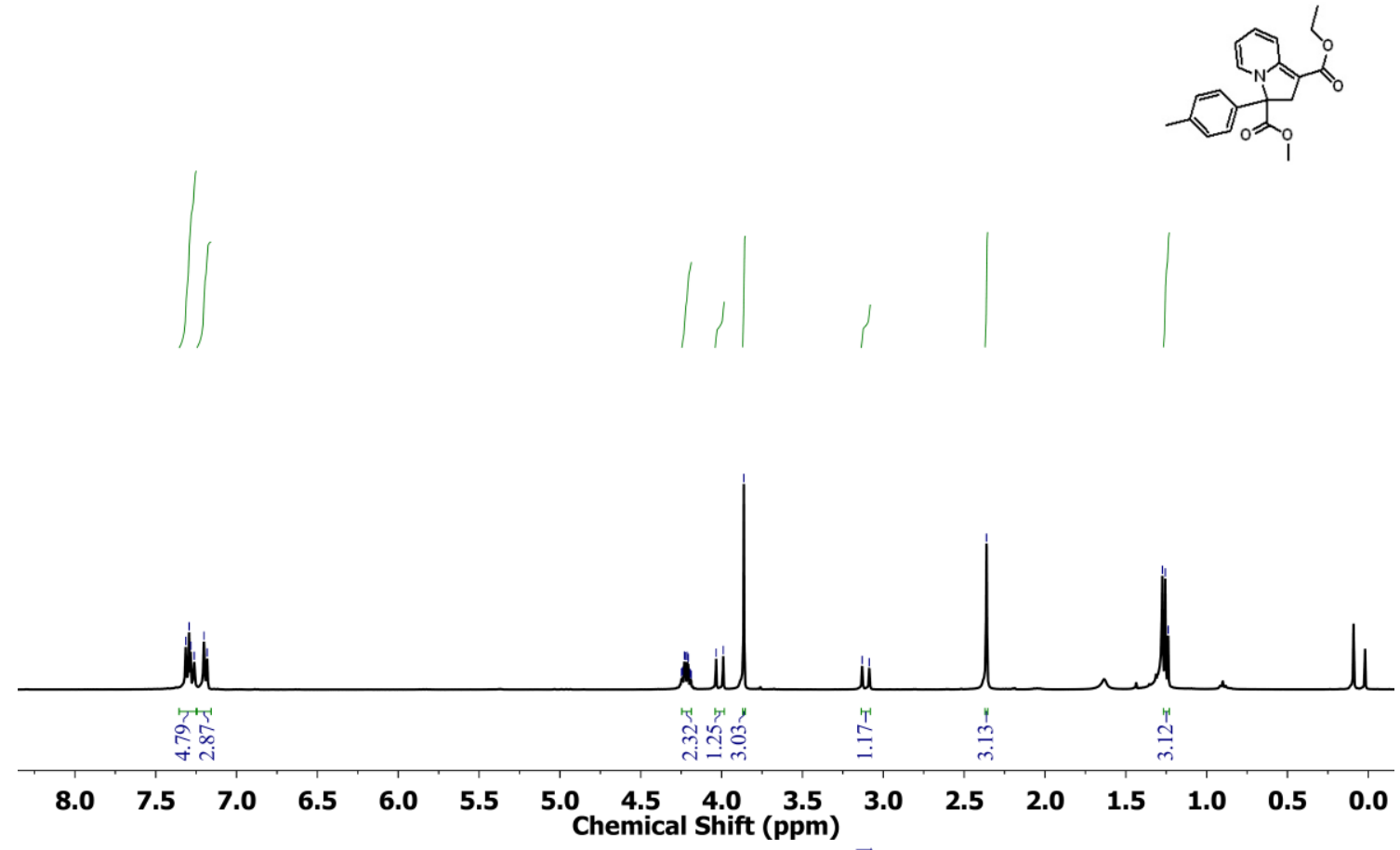

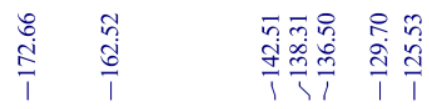
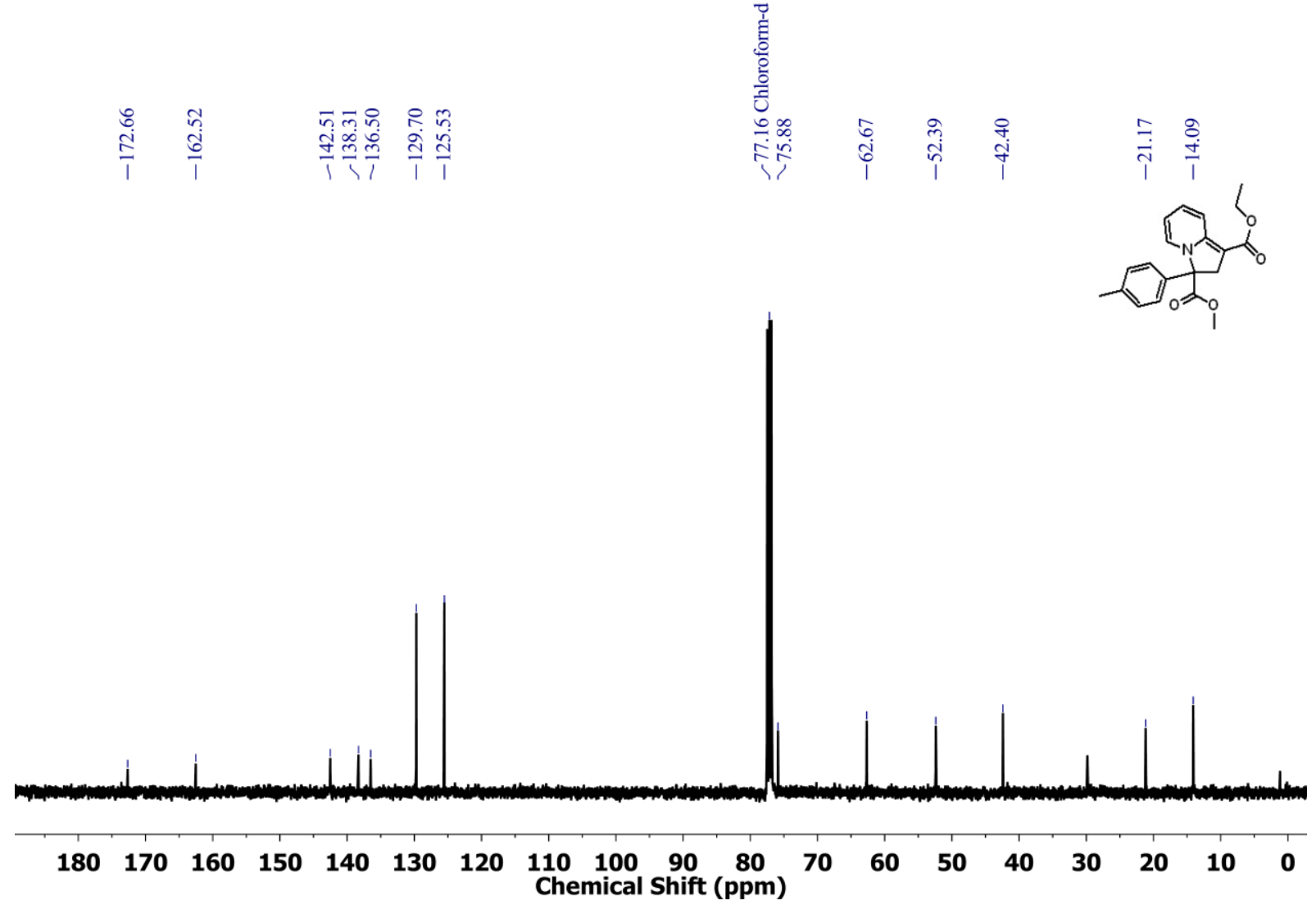
${ }^{1} \mathrm{H}(400 \mathrm{MHz})$ and ${ }^{13} \mathrm{C}\left\{{ }^{1} \mathrm{H}\right\}(100 \mathrm{MHz})$ NMR of $7 \mathbf{d}$ in $\mathrm{CDCl}_{3}$ :

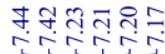

5ूละ

जiञ

रुริ
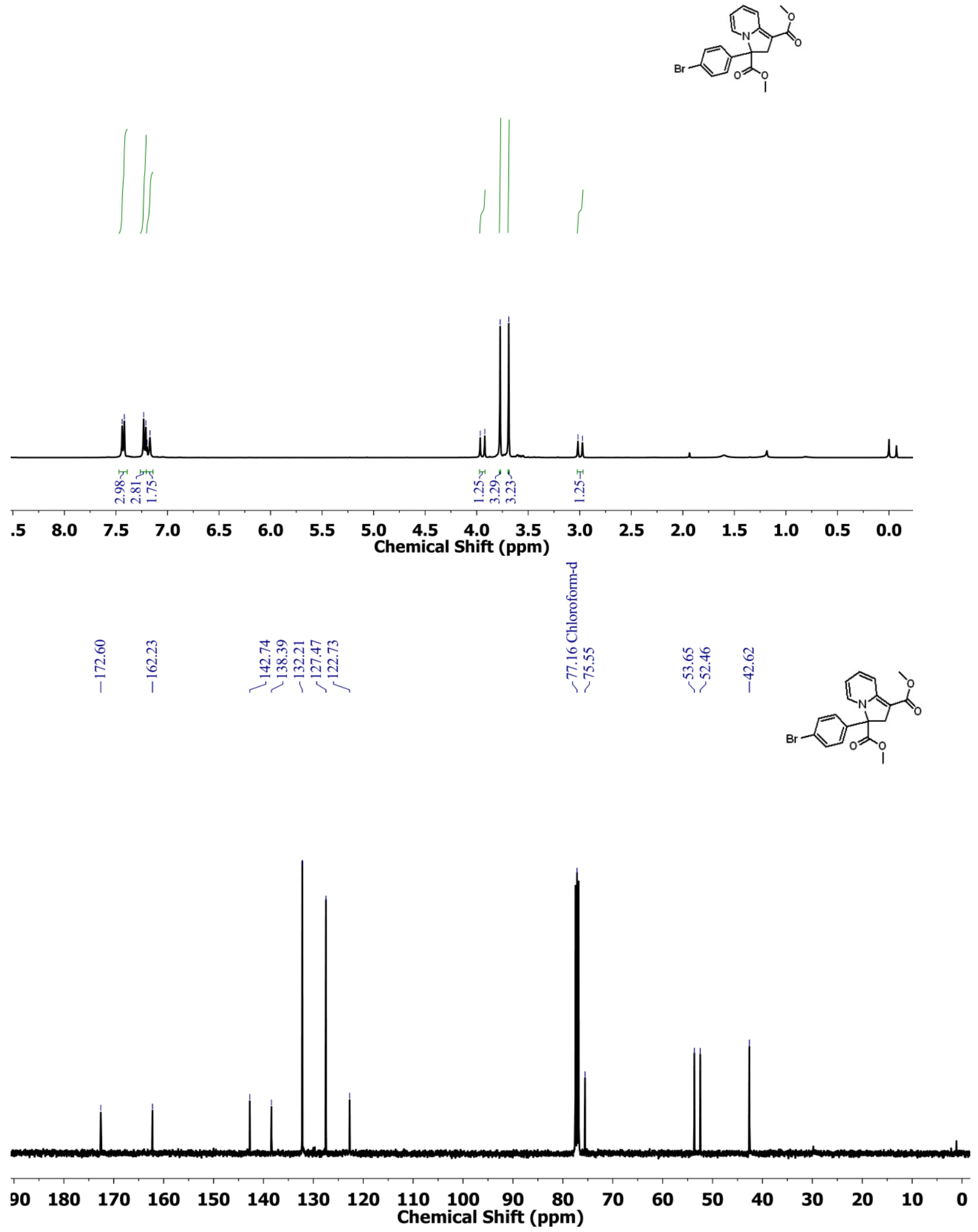
${ }^{1} \mathrm{H}(400 \mathrm{MHz}),{ }^{13} \mathrm{C}\left\{{ }^{1} \mathrm{H}\right\}(100 \mathrm{MHz})$ and ${ }^{19} \mathrm{~F}(376 \mathrm{MHz}) \mathrm{NMR}$ of $7 \mathrm{e}$ in $\mathrm{CDCl}_{3}$ :

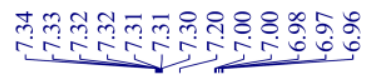

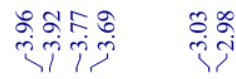
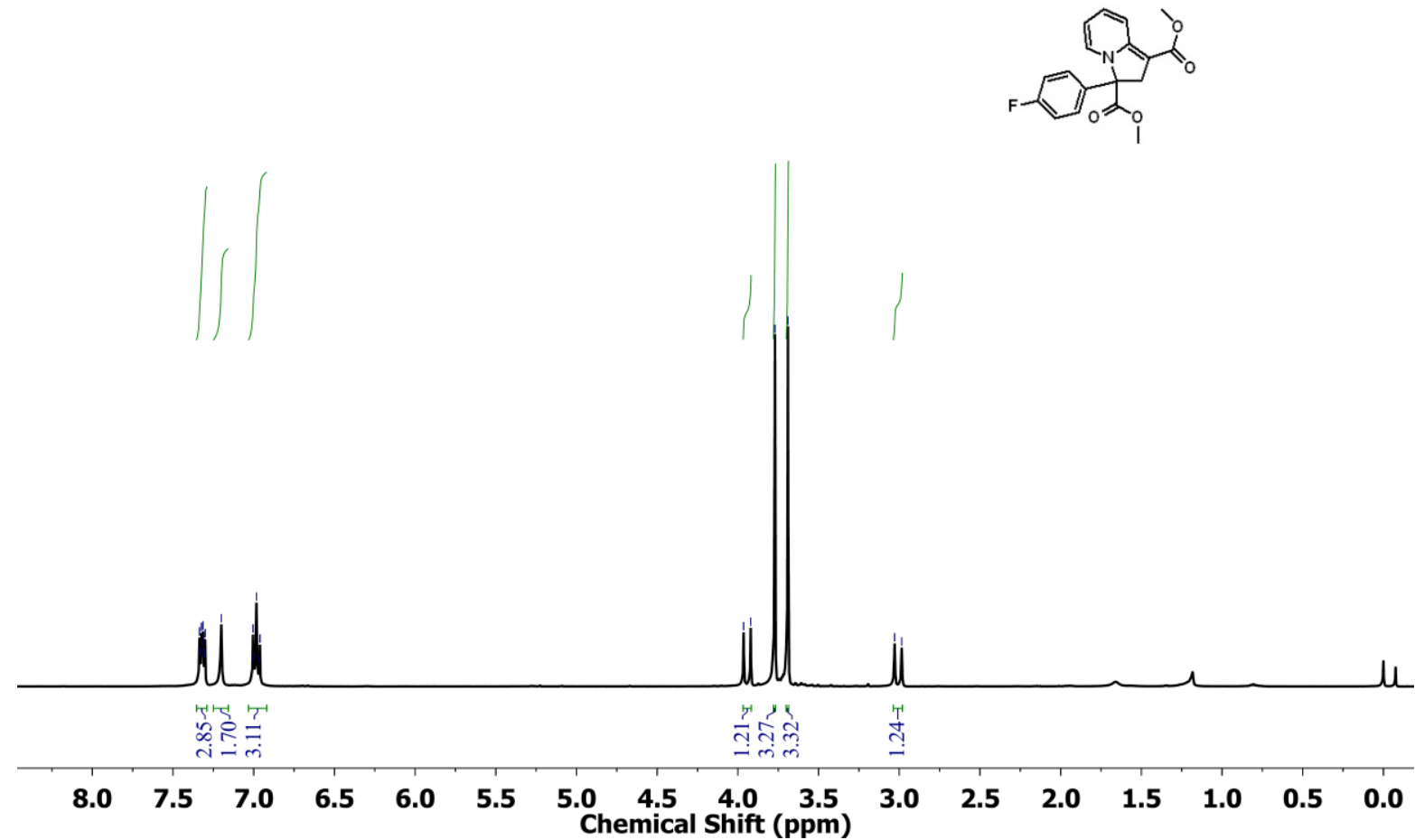

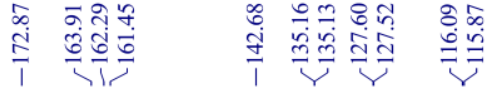
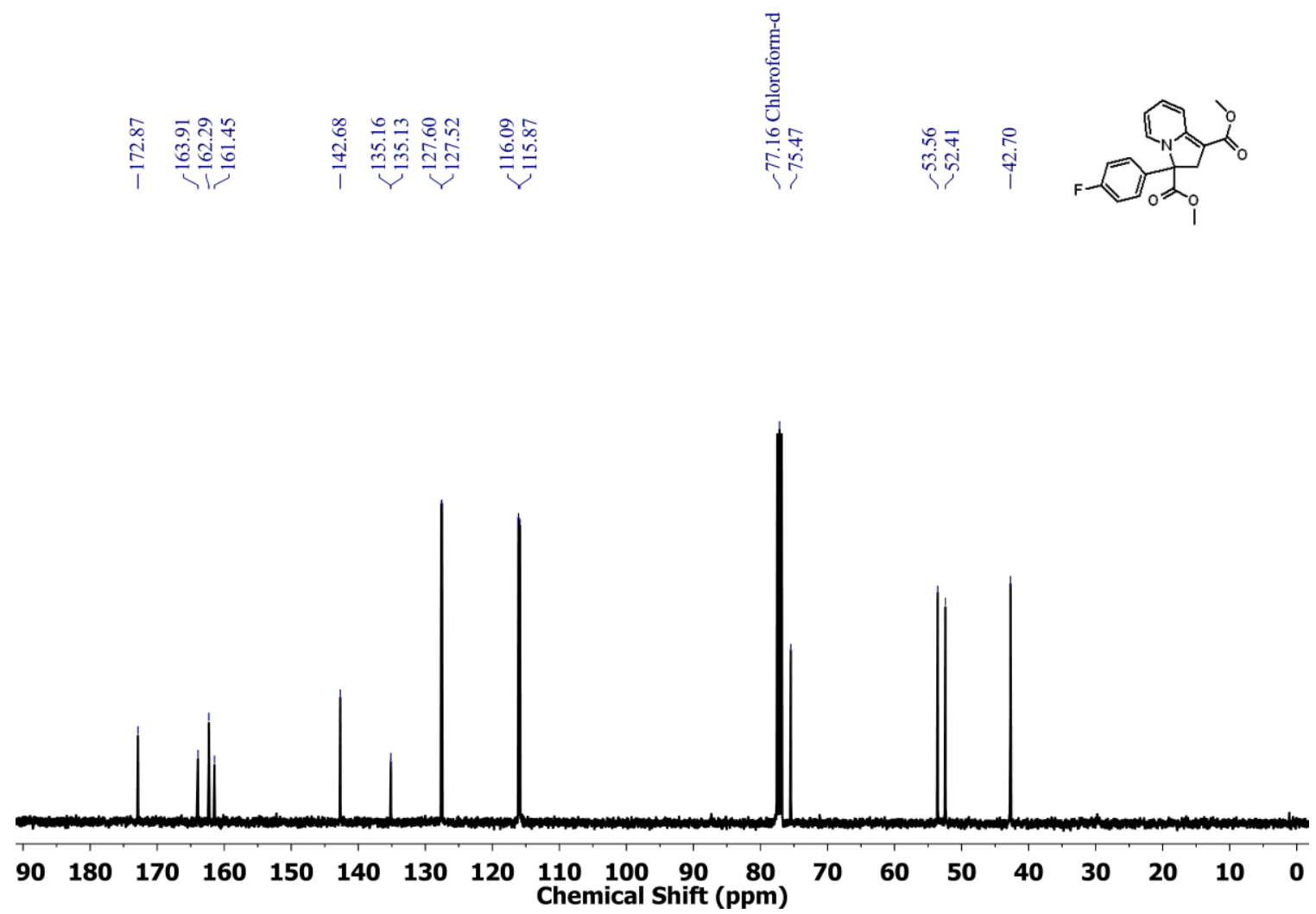

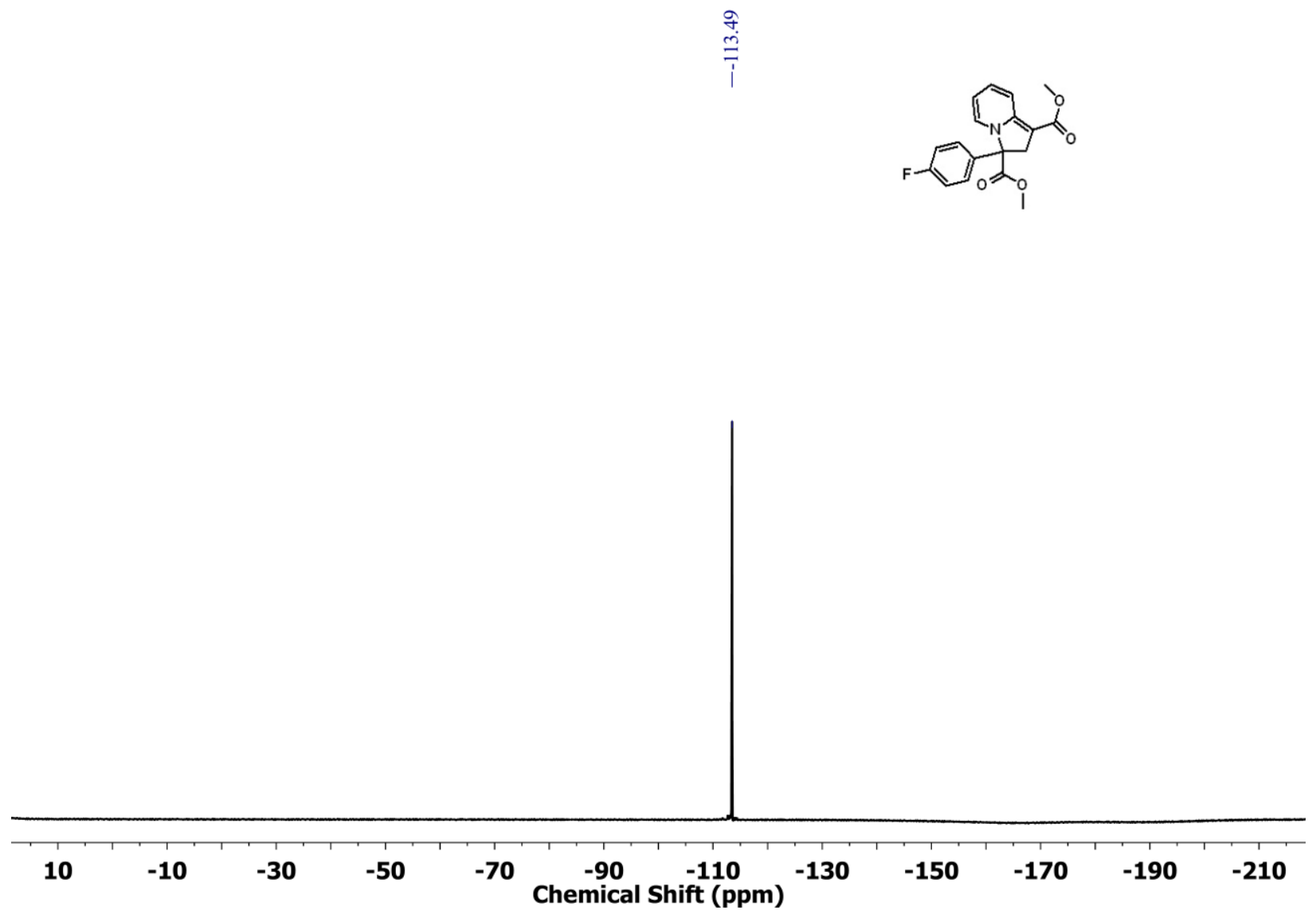
${ }^{1} \mathrm{H}(400 \mathrm{MHz})$ and ${ }^{13} \mathrm{C}\left\{{ }^{1} \mathrm{H}\right\}(100 \mathrm{MHz})$ NMR of $7 \mathrm{f}$ in $\mathrm{CDCl}_{3}$ :

in

은

मंगुल भंग
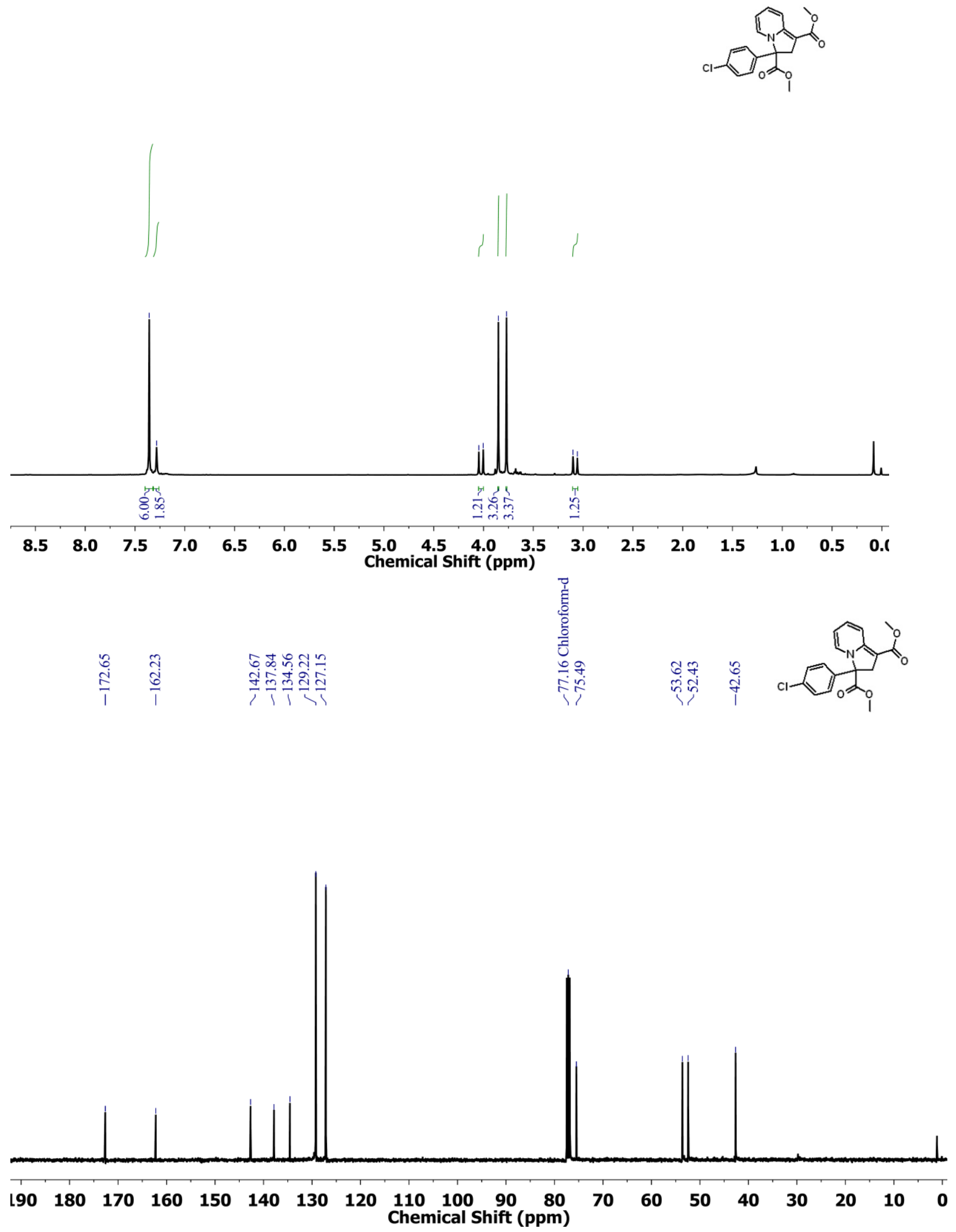
${ }^{1} \mathrm{H}(400 \mathrm{MHz}),{ }^{13} \mathrm{C}\left\{{ }^{1} \mathrm{H}\right\}(100 \mathrm{MHz})$ and ${ }^{19} \mathrm{~F}(376 \mathrm{MHz}) \mathrm{NMR}$ of $7 \mathrm{~g}$ in $\mathrm{CDCl}_{3}$ :

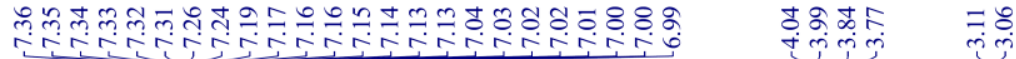

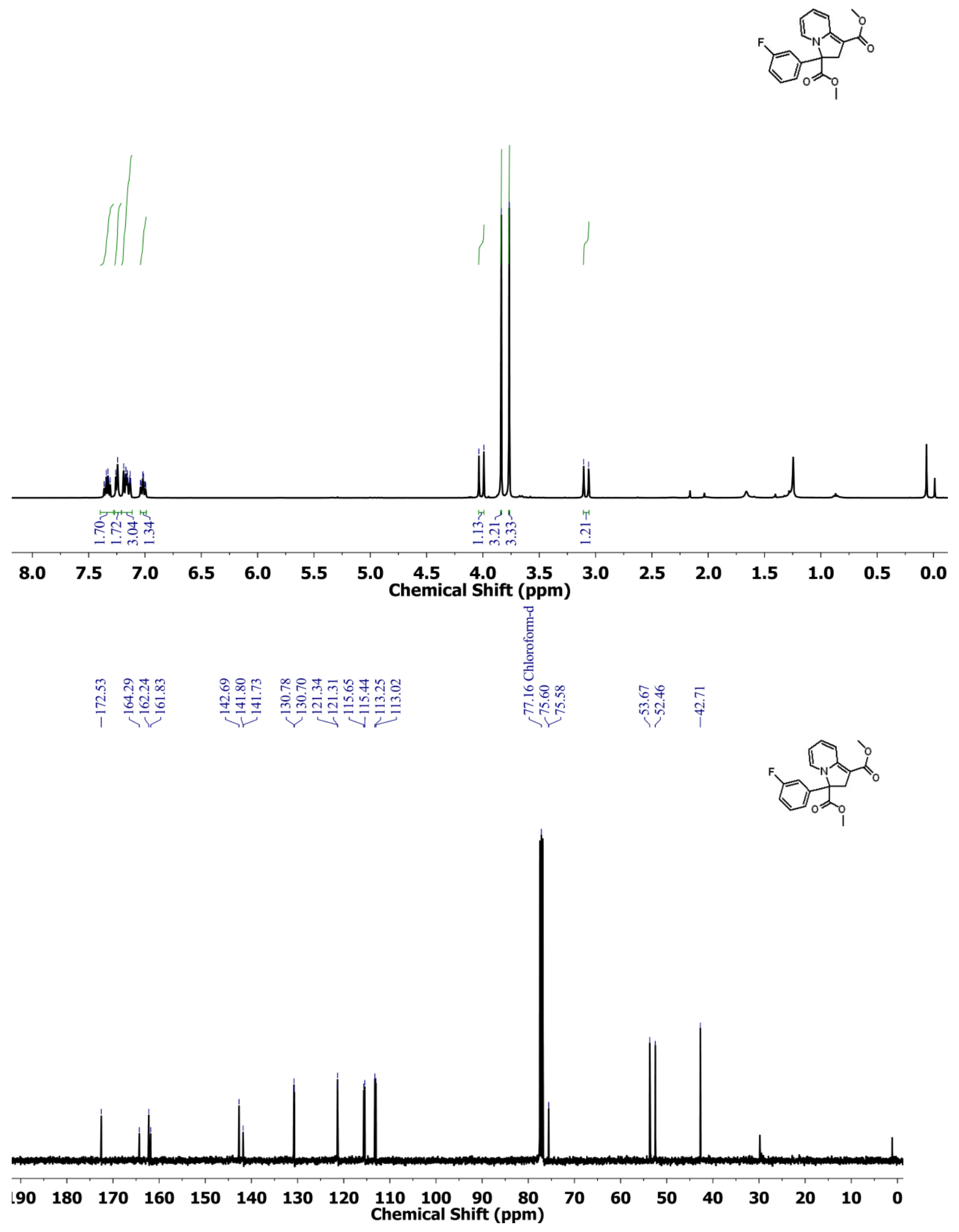



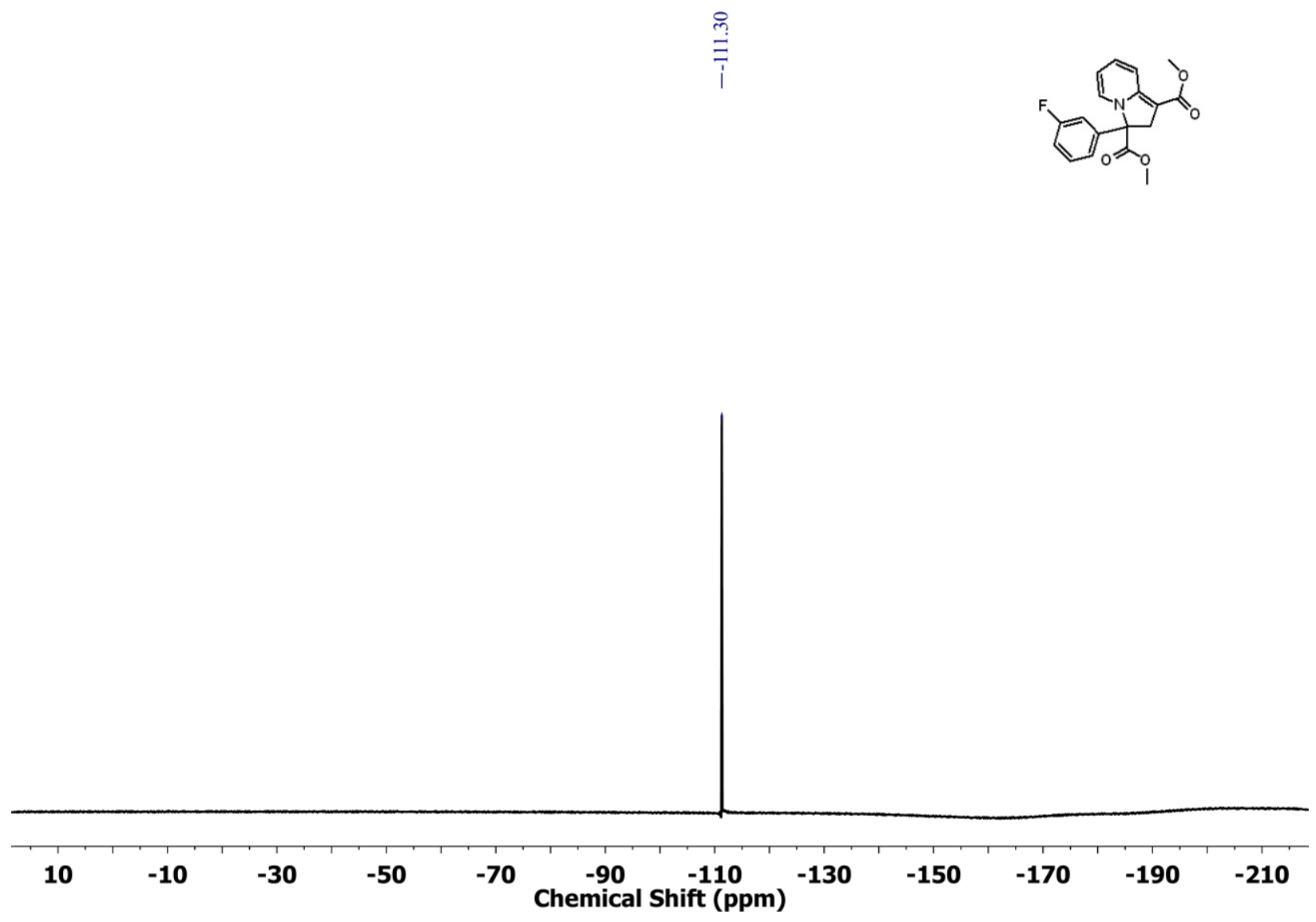
${ }^{1} \mathrm{H}(400 \mathrm{MHz})$ and ${ }^{13} \mathrm{C}\left\{{ }^{1} \mathrm{H}\right\}(100 \mathrm{MHz}) \mathrm{NMR}$ of $\mathbf{7 h}$ in $\mathrm{CDCl}_{3}$ :

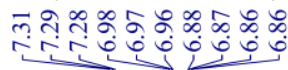

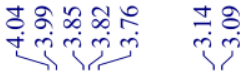
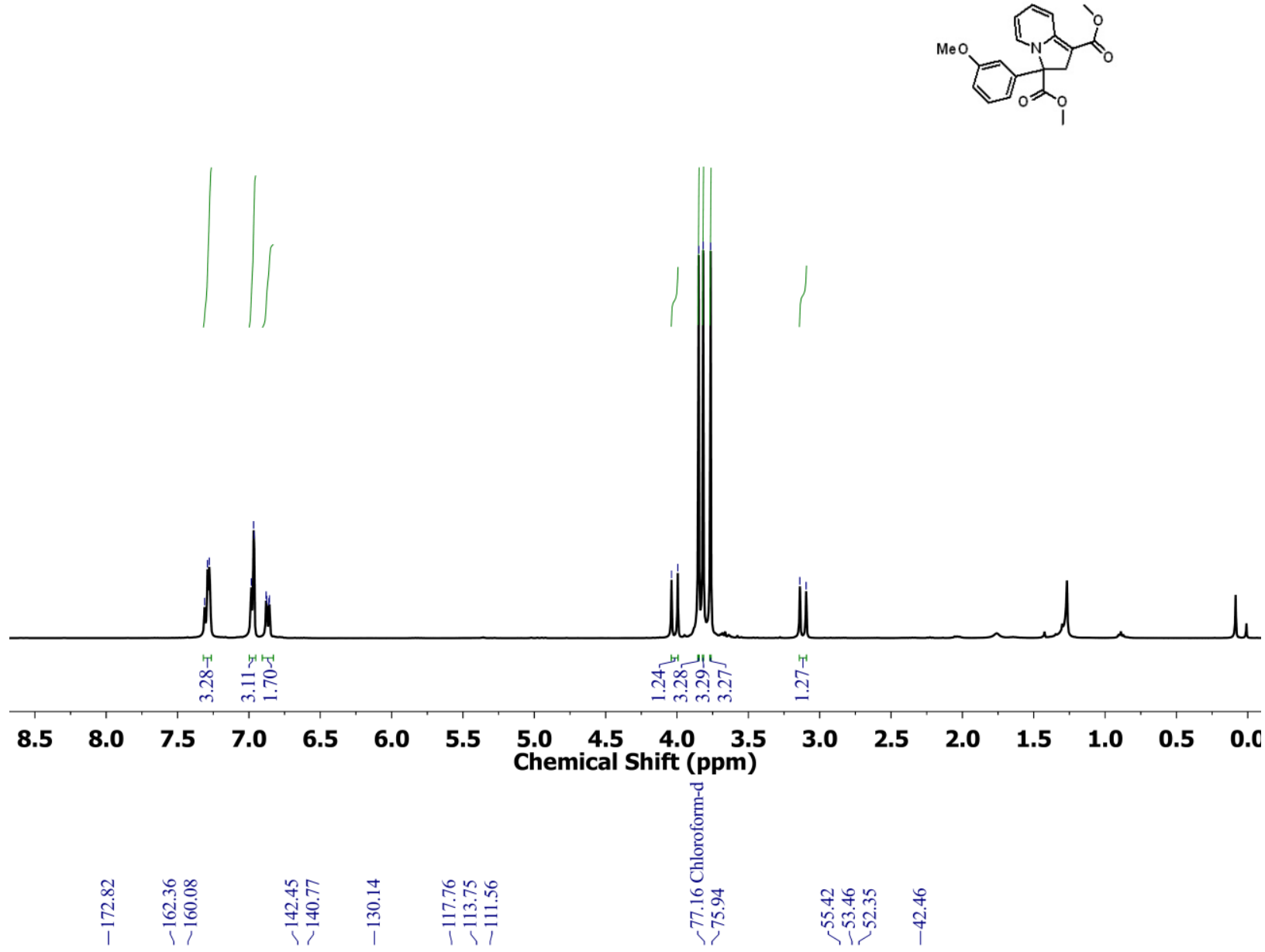

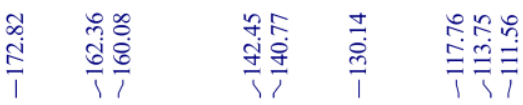
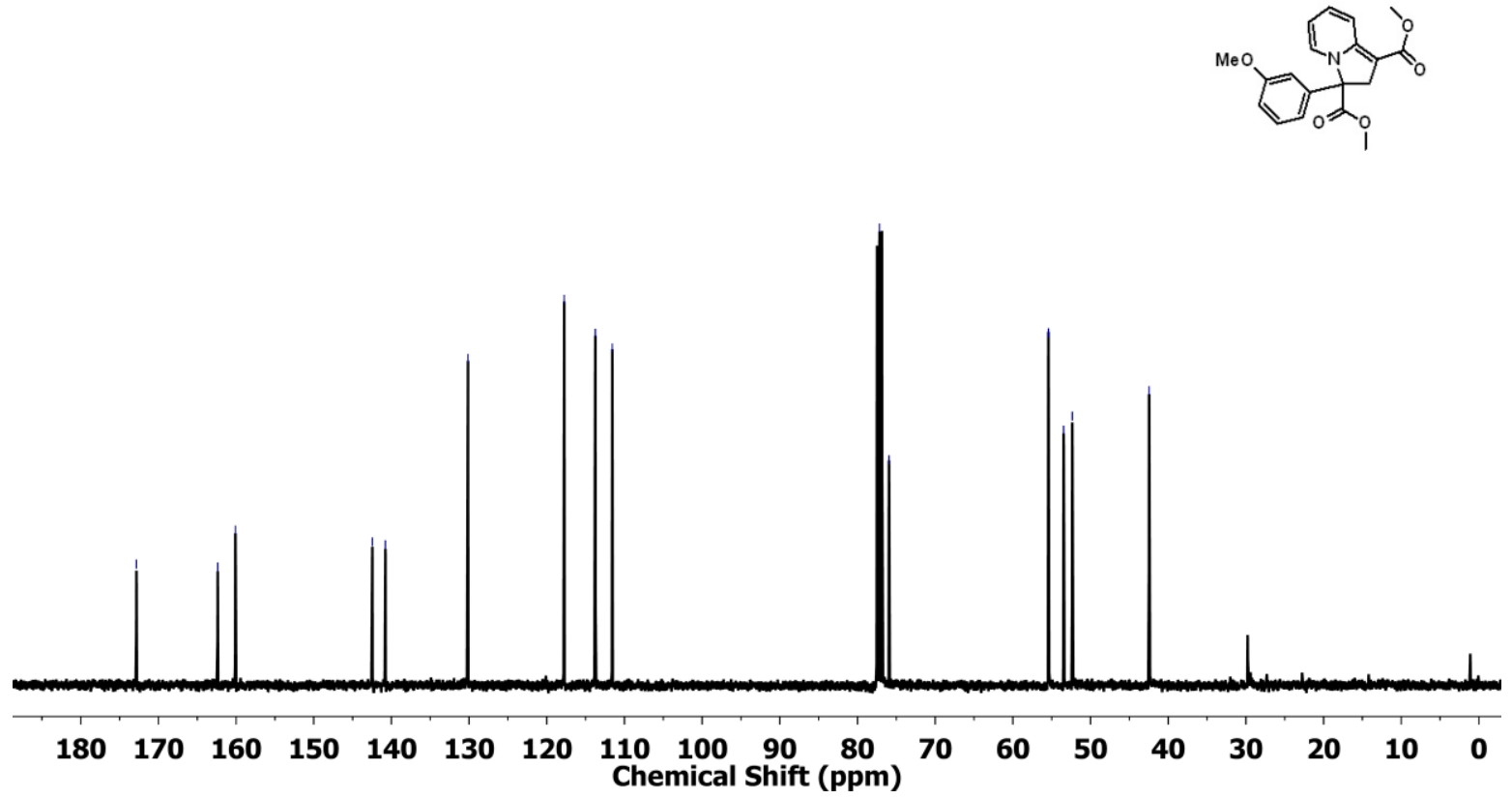
${ }^{1} \mathrm{H}(400 \mathrm{MHz})$ and ${ }^{13} \mathrm{C}\left\{{ }^{1} \mathrm{H}\right\}(100 \mathrm{MHz})$ NMR of $7 \mathbf{i}$ in $\mathrm{CDCl}_{3}$ :

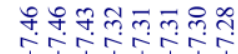

$\because-\infty \infty$

近

ํㅗㅇ
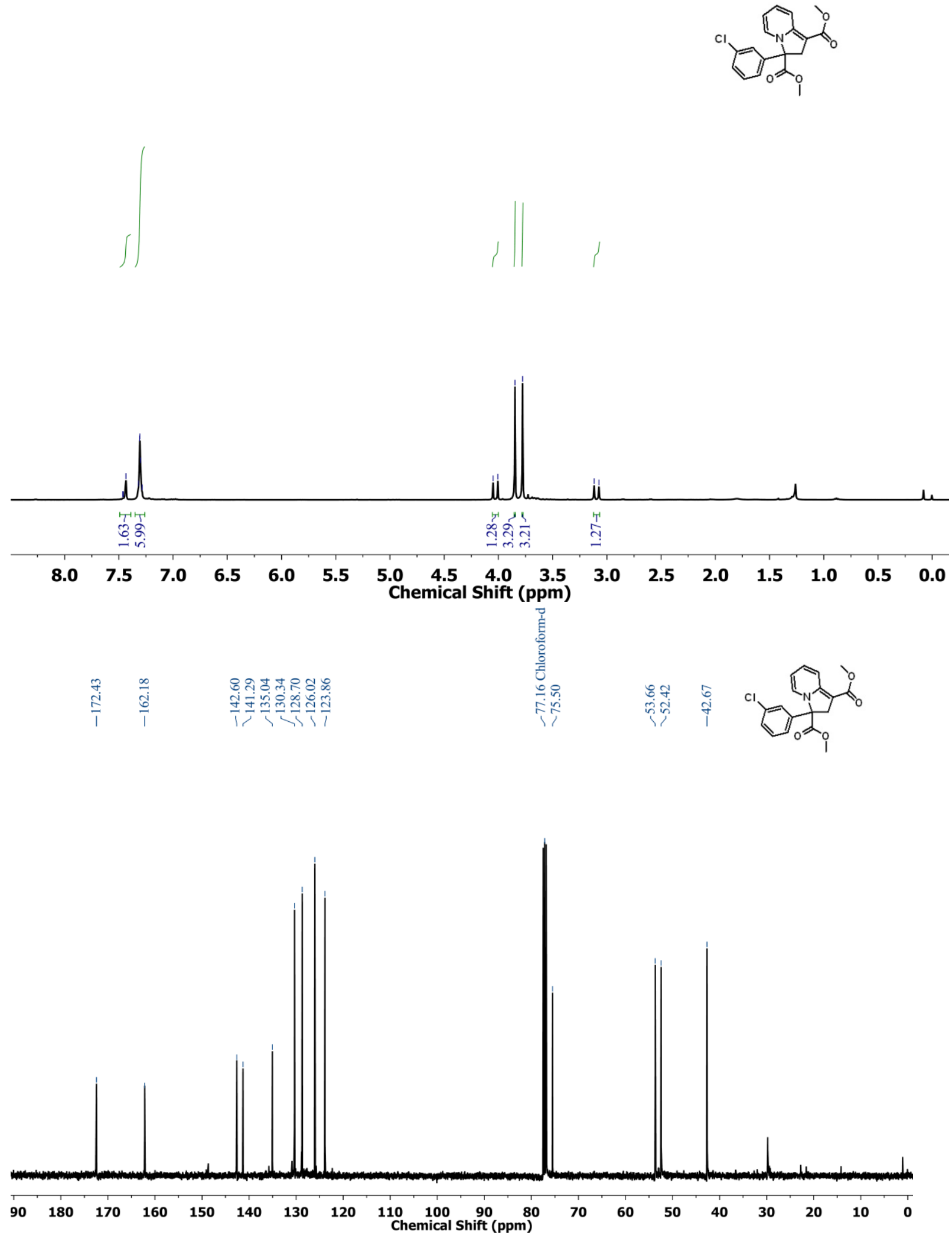
${ }^{1} \mathrm{H}(400 \mathrm{MHz})$ and ${ }^{13} \mathrm{C}\left\{{ }^{1} \mathrm{H}\right\}(100 \mathrm{MHz}) \mathrm{NMR}$ of $7 \mathrm{j}$ in $\mathrm{CDCl}_{3}$ :

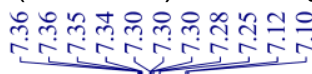
สิกิที丶万仒

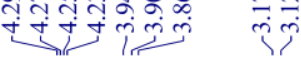
귤
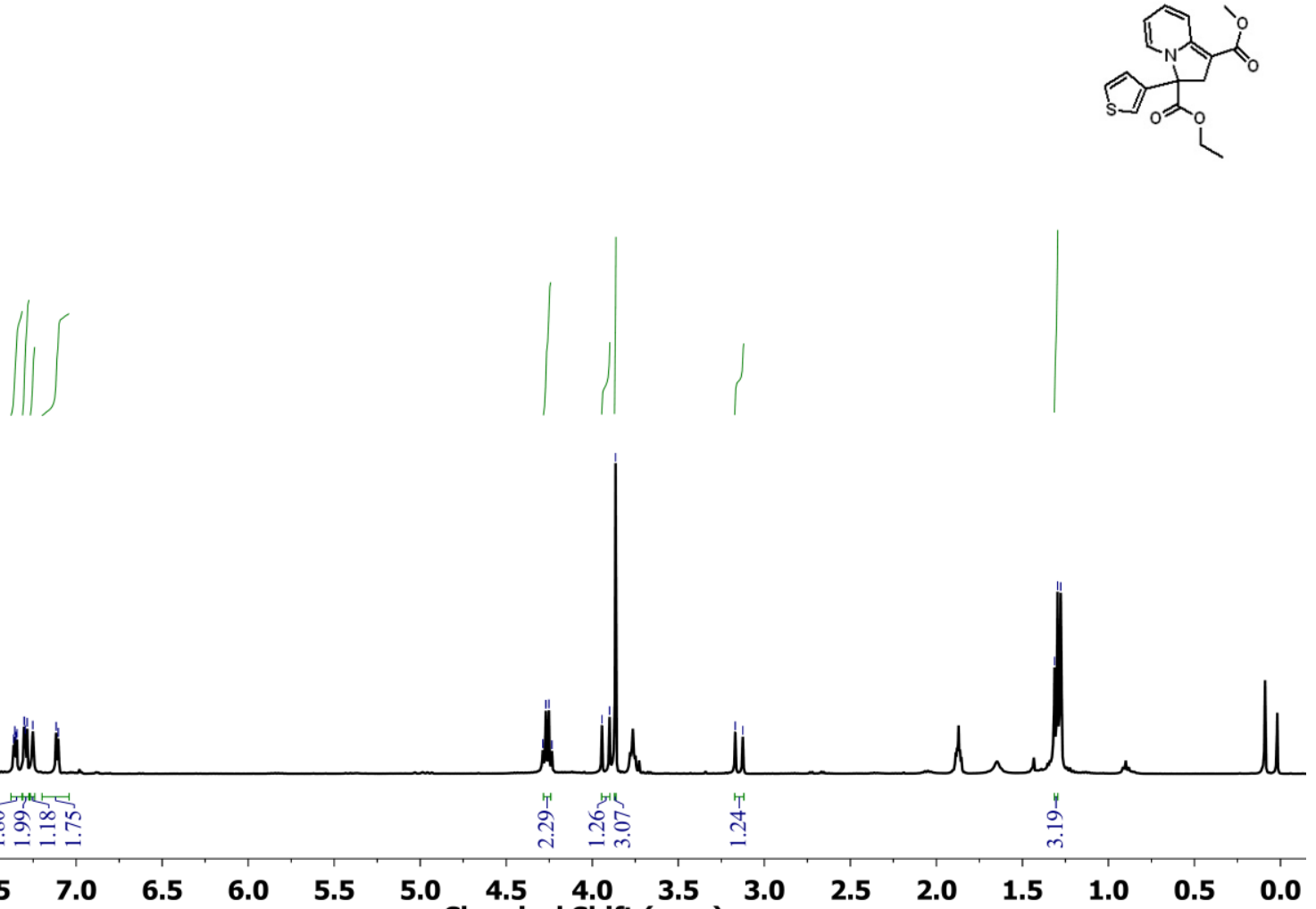

8.

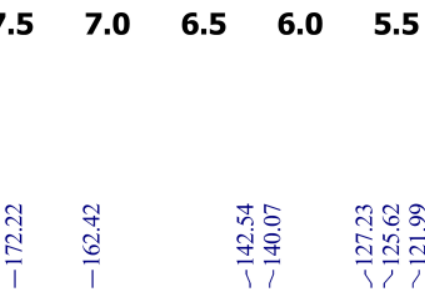

Chemical Shift (ppm)

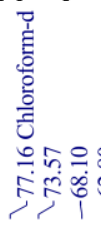

กั

în

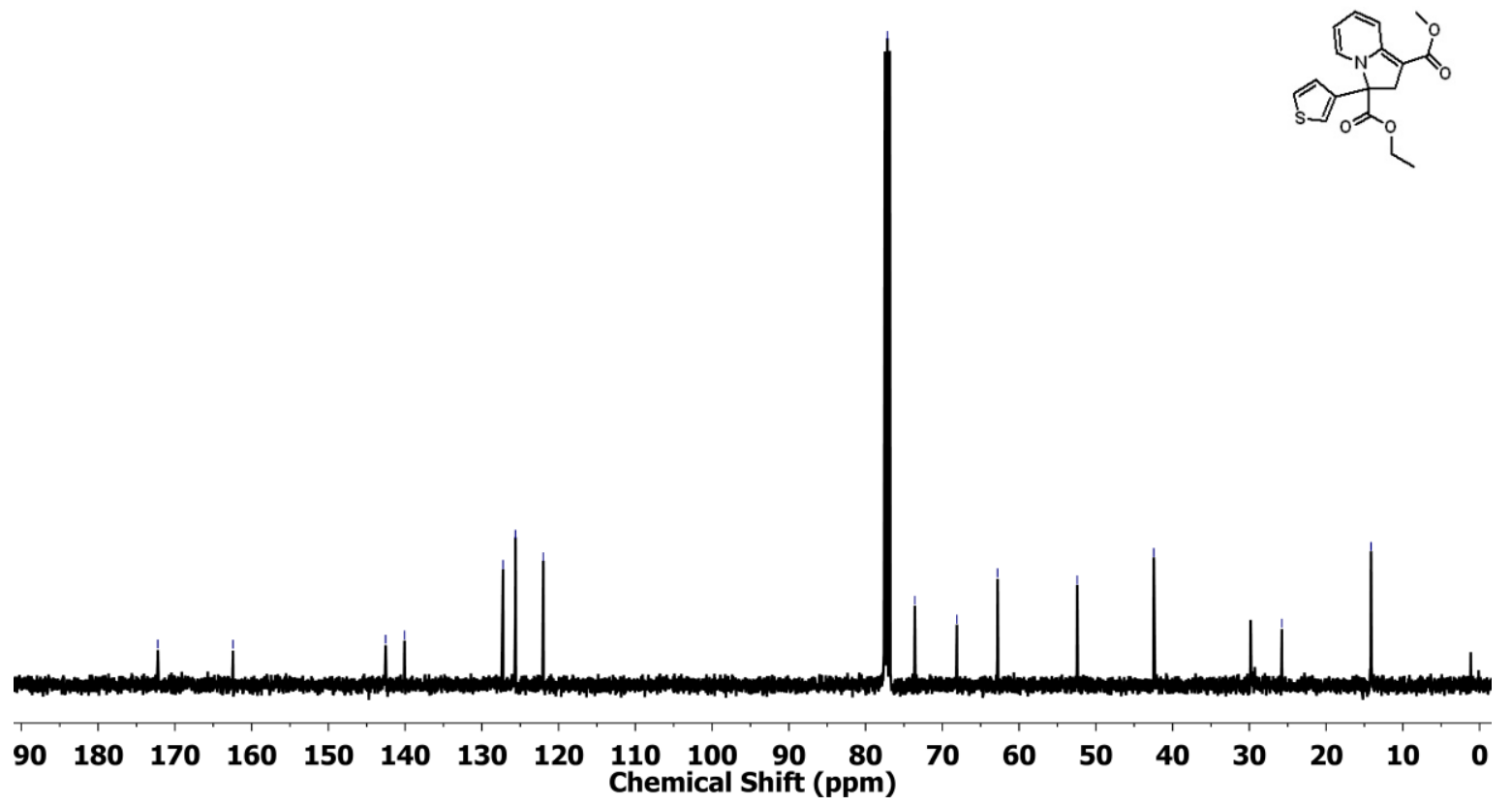


${ }^{1} \mathrm{H}(400 \mathrm{MHz})$ and ${ }^{13} \mathrm{C}\left\{{ }^{1} \mathrm{H}\right\}(100 \mathrm{MHz}) \mathrm{NMR}$ of $7 \mathbf{k}$ in $\mathrm{CDCl}_{3}$ :

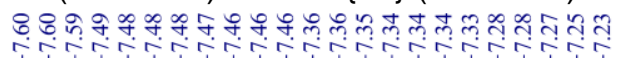

în

निं
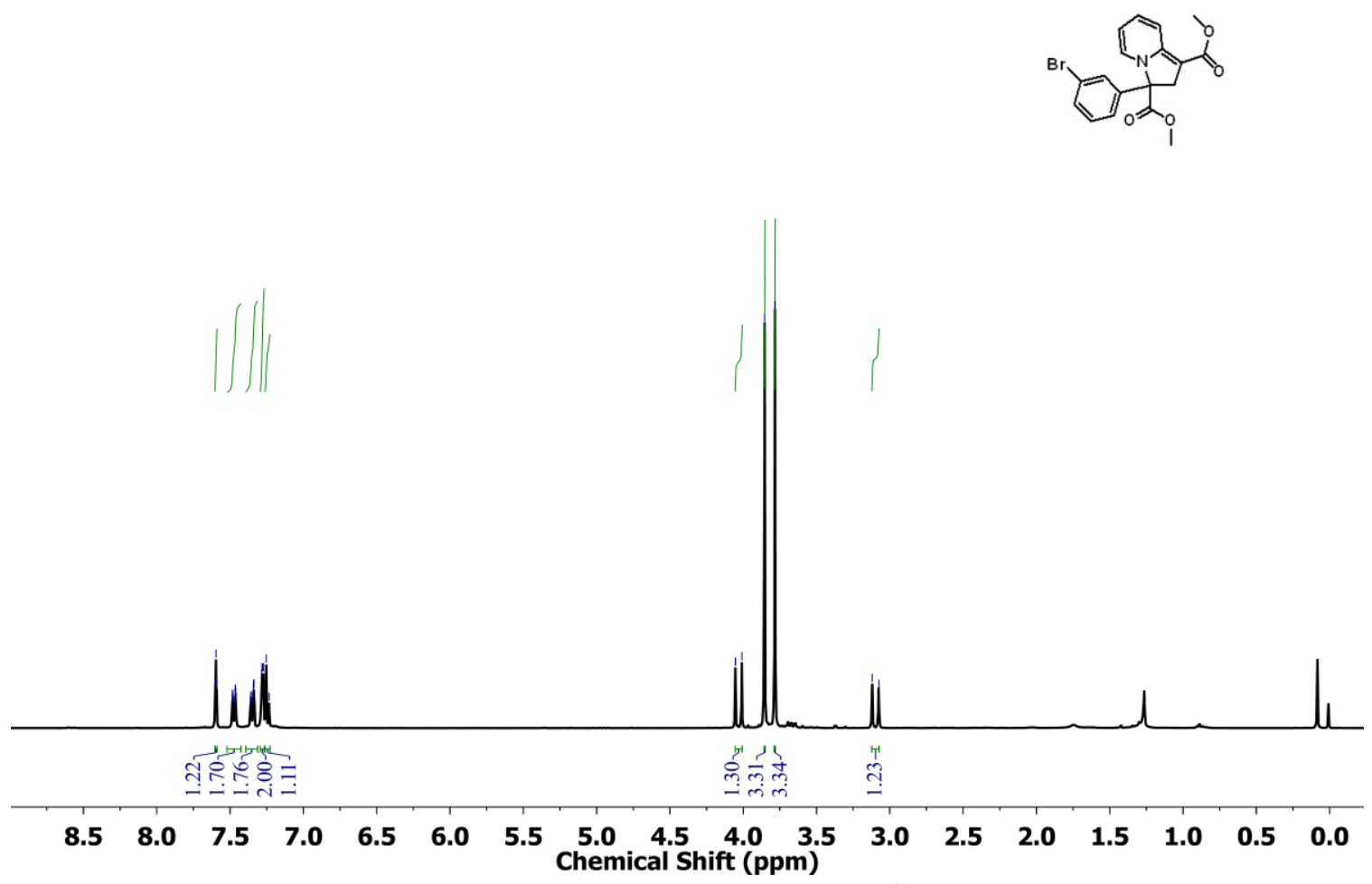

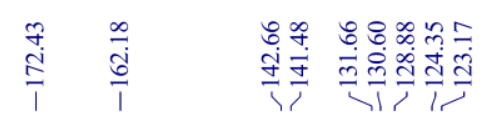

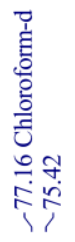

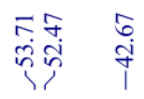
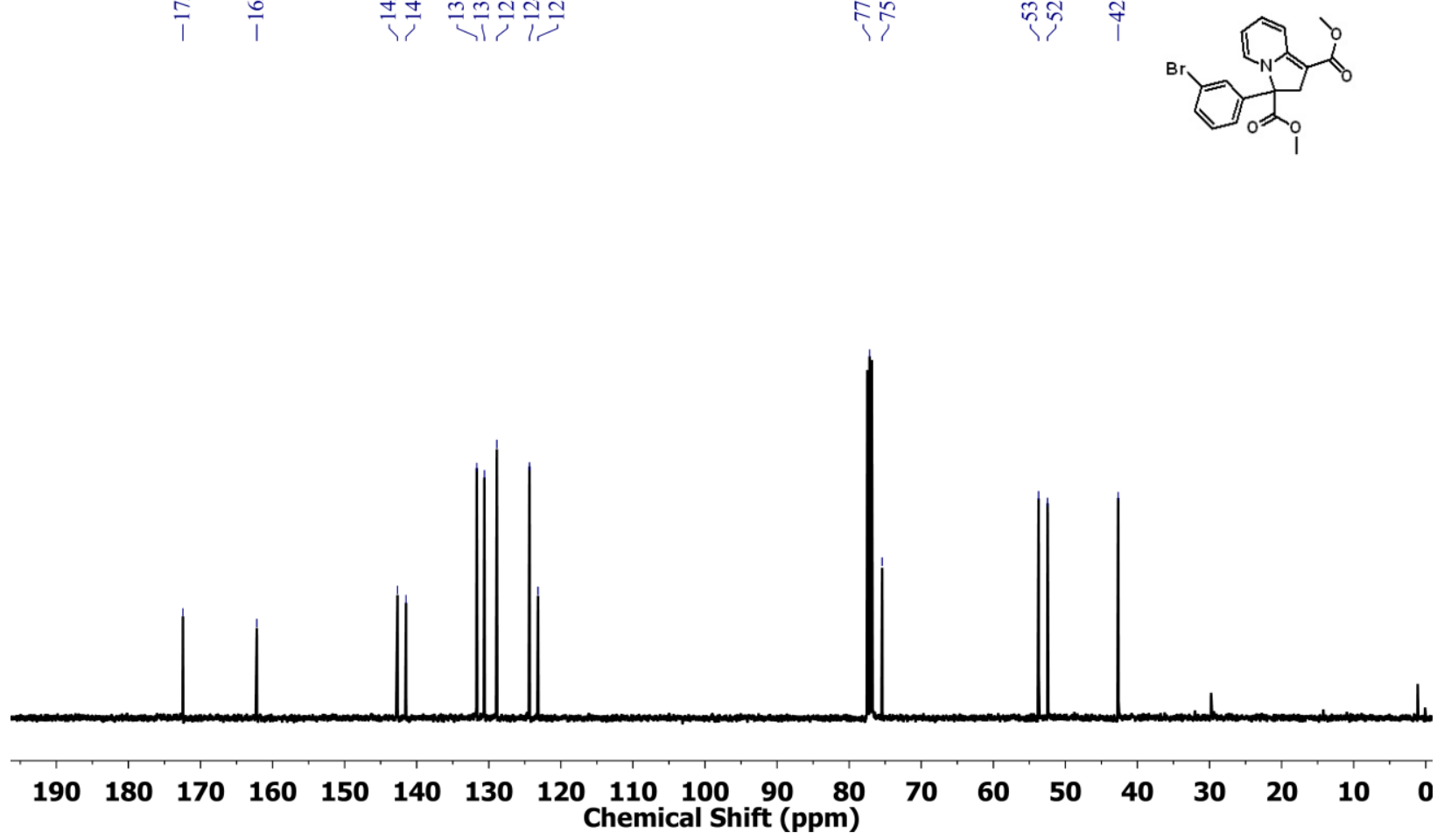

S19 
${ }^{1} \mathrm{H}(400 \mathrm{MHz})$ and ${ }^{13} \mathrm{C}\left\{{ }^{1} \mathrm{H}\right\}(100 \mathrm{MHz}) \mathrm{NMR}$ of $7 \mathrm{I}$ in $\mathrm{CDCl}_{3}$ :

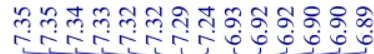

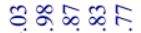
लंiुं भiक
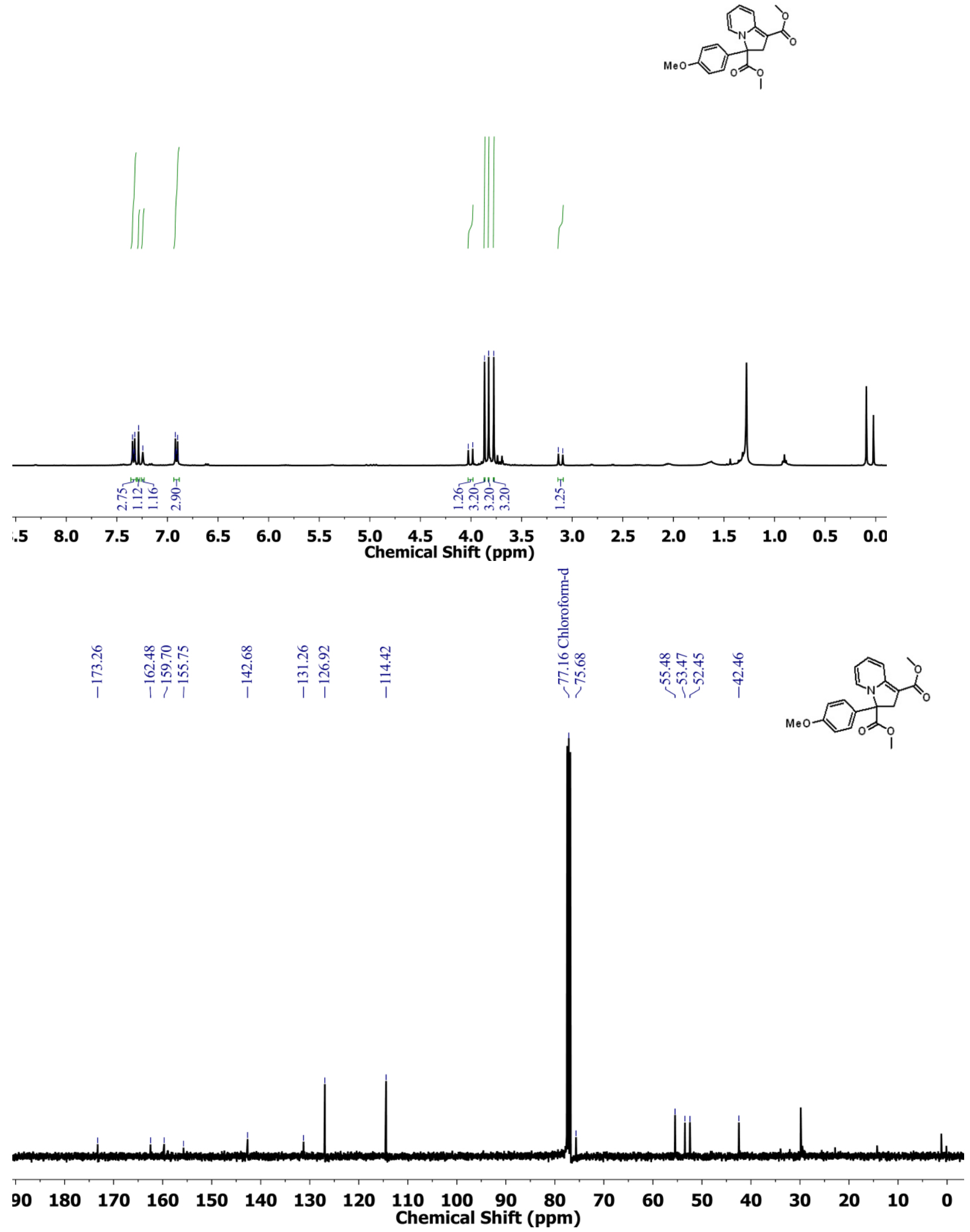
${ }^{1} \mathrm{H}(400 \mathrm{MHz})$ and ${ }^{13} \mathrm{C}\left\{{ }^{1} \mathrm{H}\right\}(100 \mathrm{MHz})$ NMR of $8 \mathbf{a}$ in $\mathrm{CDCl}_{3}$ :
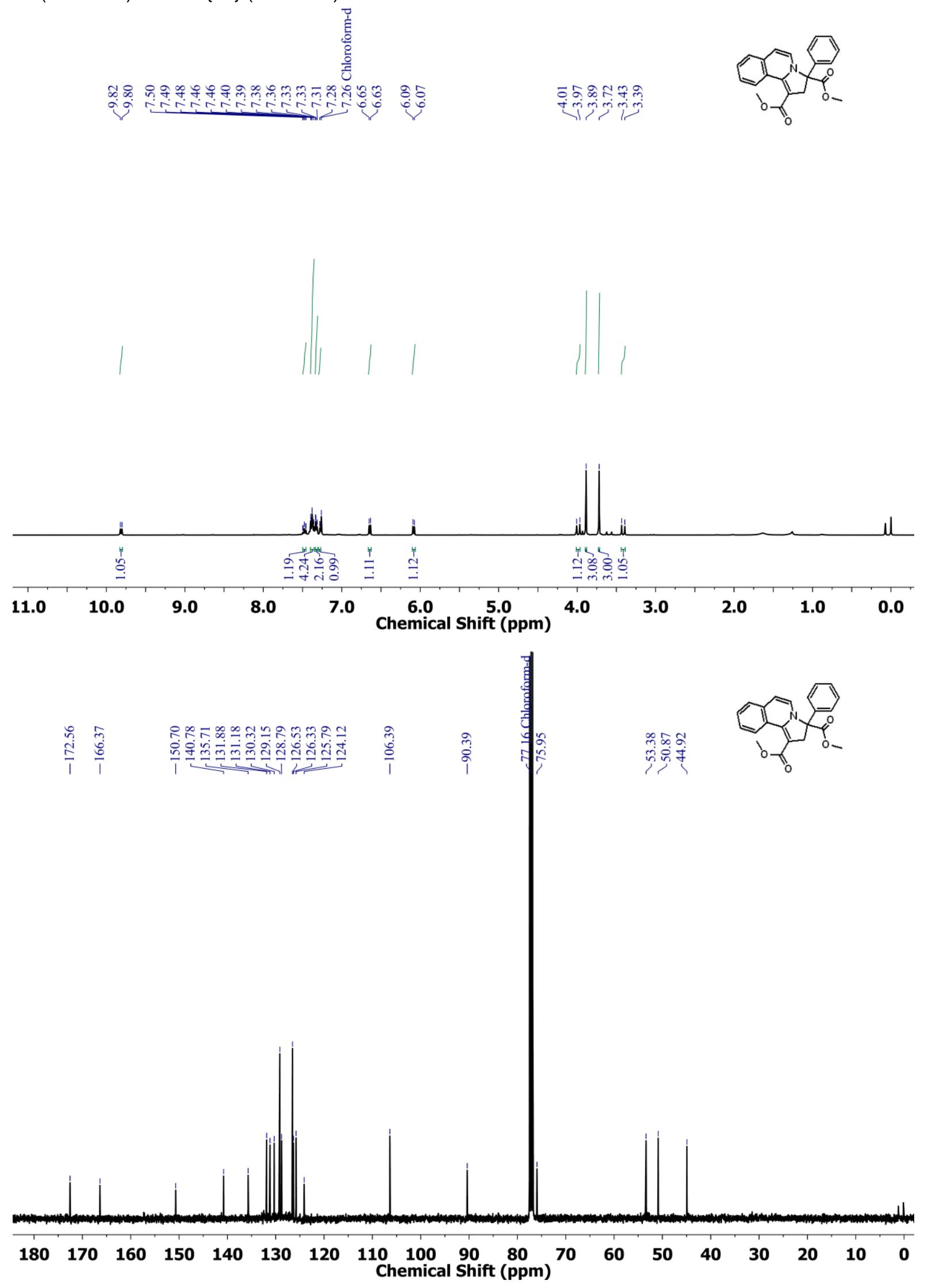
${ }^{1} \mathrm{H}(400 \mathrm{MHz})$ and ${ }^{13} \mathrm{C}\left\{{ }^{1} \mathrm{H}\right\}(100 \mathrm{MHz})$ NMR of $8 \mathbf{b}$ in $\mathrm{CDCl}_{3}$ :

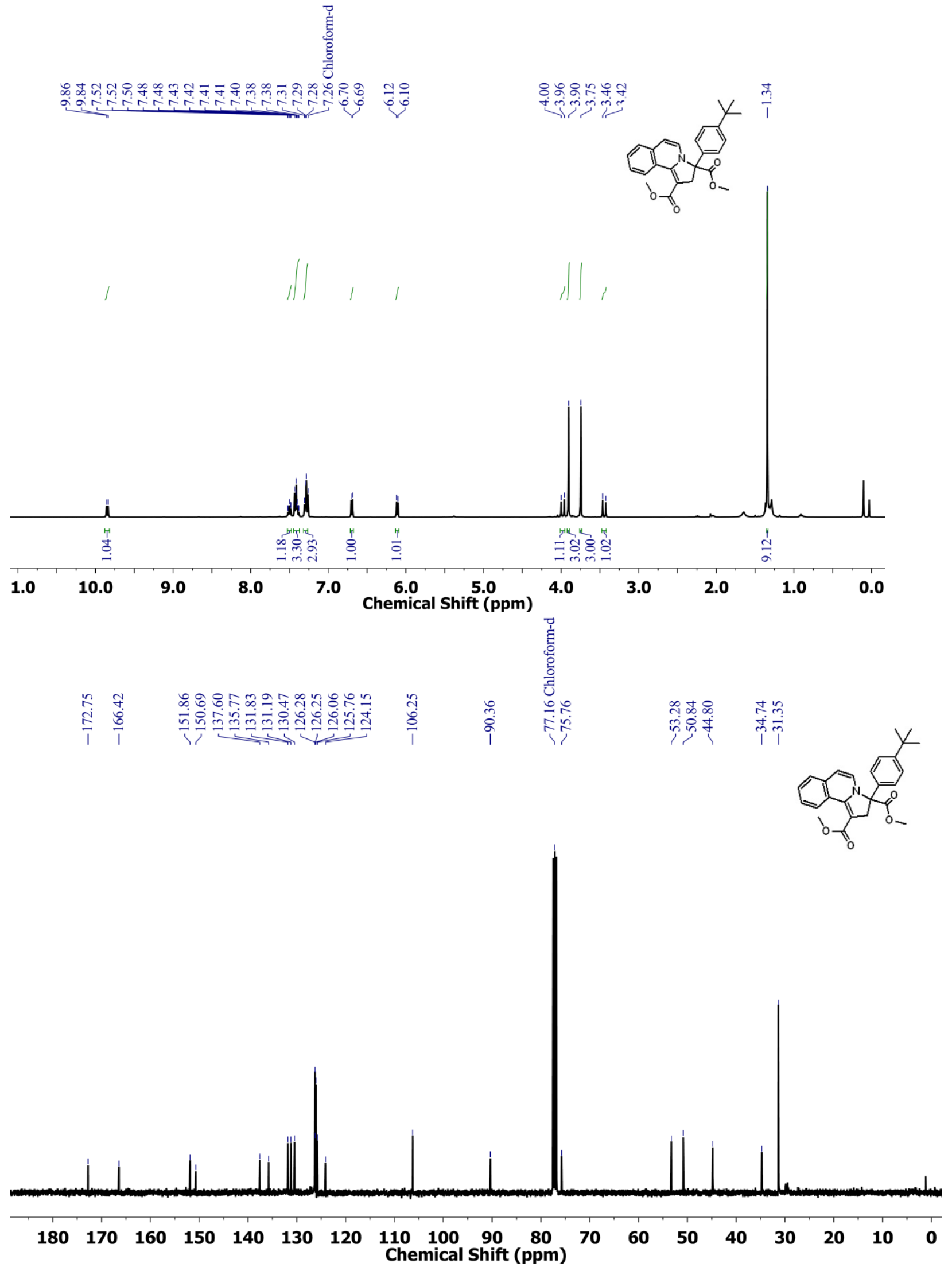


${ }^{1} \mathrm{H}(400 \mathrm{MHz})$ and ${ }^{13} \mathrm{C}\left\{{ }^{1} \mathrm{H}\right\}(100 \mathrm{MHz})$ NMR of $8 \mathrm{c}$ in $\mathrm{CDCl}_{3}$ :
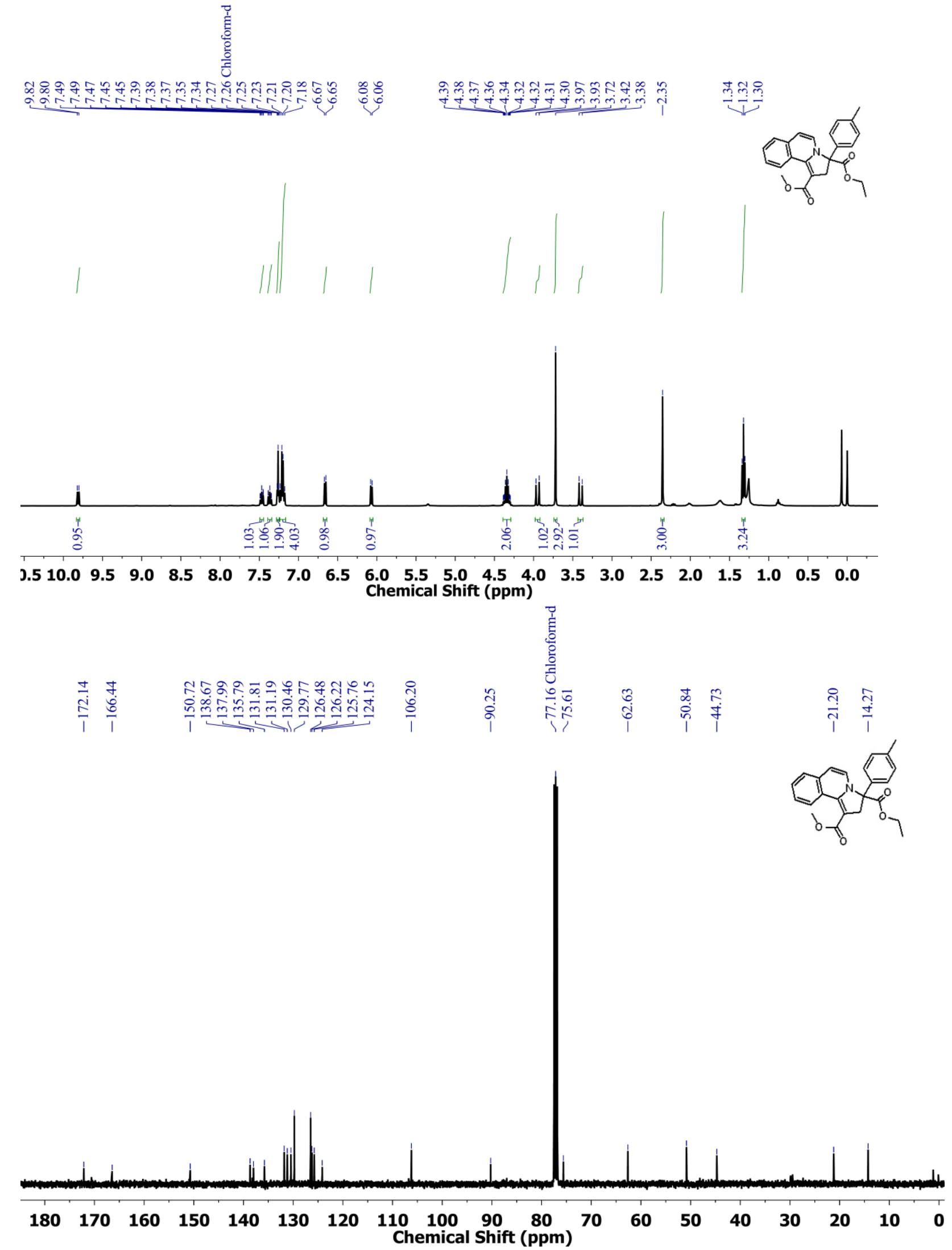
${ }^{1} \mathrm{H}(400 \mathrm{MHz})$ and ${ }^{13} \mathrm{C}\left\{{ }^{1} \mathrm{H}\right\}(100 \mathrm{MHz}) \mathrm{NMR}$ of $8 \mathbf{d}$ in $\mathrm{CDCl}_{3}$ :
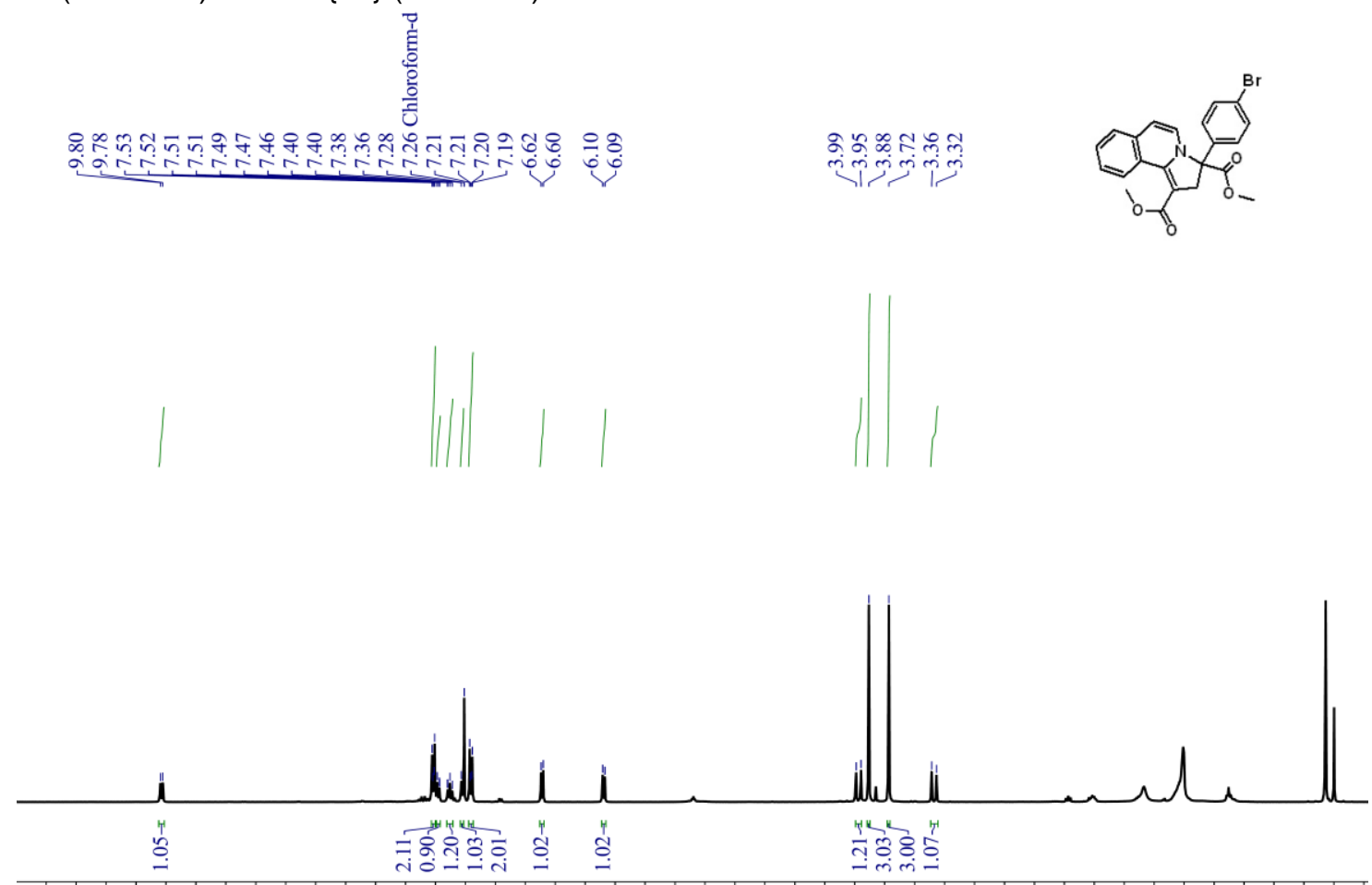

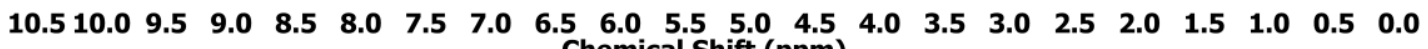
Chemical Shift (ppm)

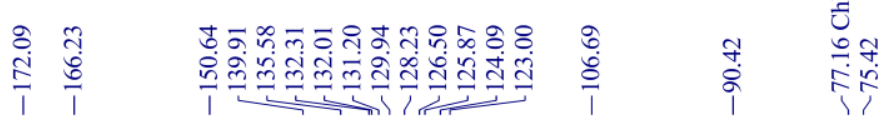

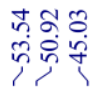
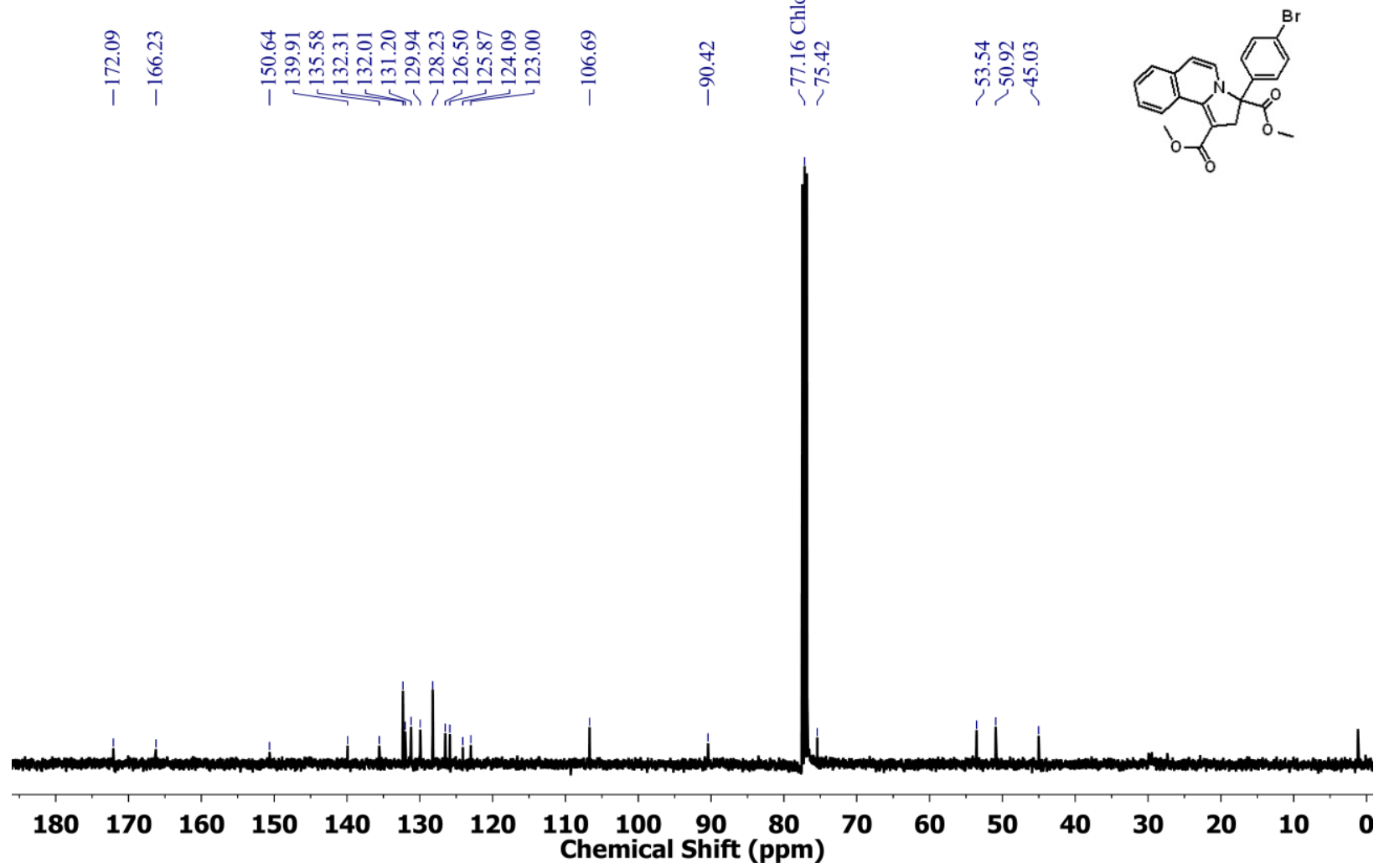
${ }^{1} \mathrm{H}(400 \mathrm{MHz}),{ }^{13} \mathrm{C}\left\{{ }^{1} \mathrm{H}\right\}(100 \mathrm{MHz})$ and ${ }^{19} \mathrm{~F}(376 \mathrm{MHz}) \mathrm{NMR}$ of $8 \mathrm{e}$ in $\mathrm{CDCl}_{3}:$
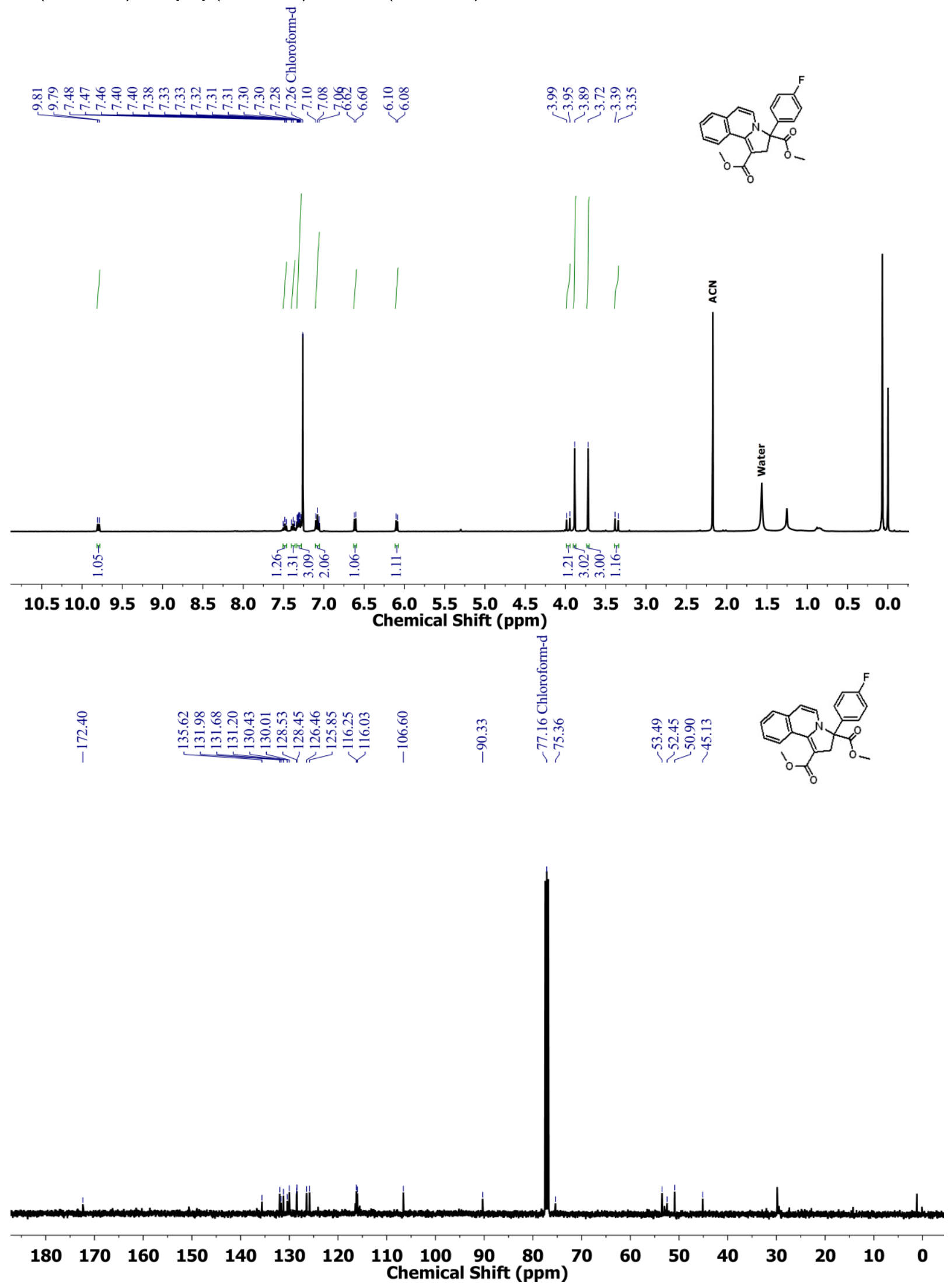

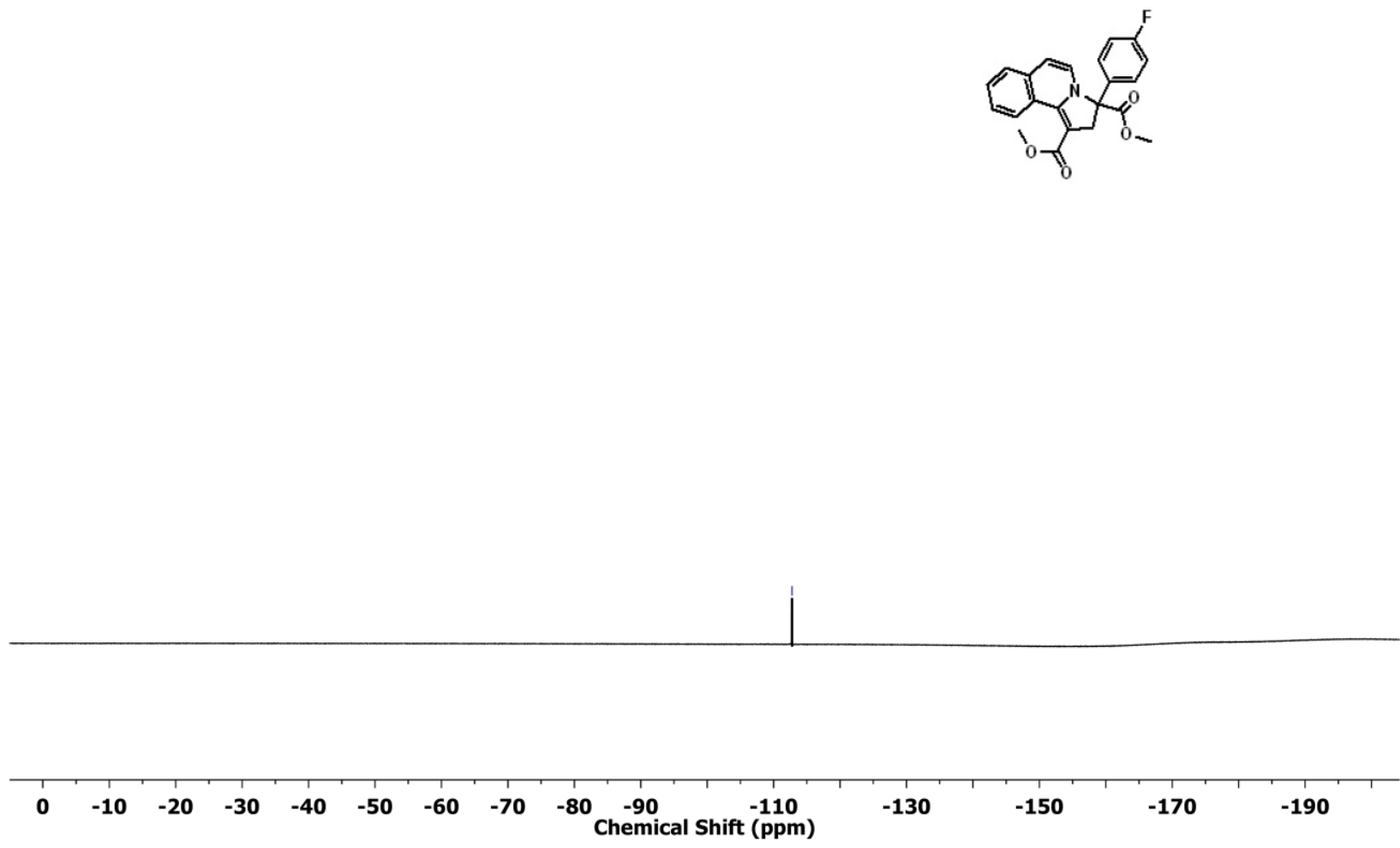
${ }^{1} \mathrm{H}(400 \mathrm{MHz})$ and ${ }^{13} \mathrm{C}\left\{{ }^{1} \mathrm{H}\right\}(100 \mathrm{MHz})$ NMR of 8 in $\mathrm{CDCl}_{3}$ :
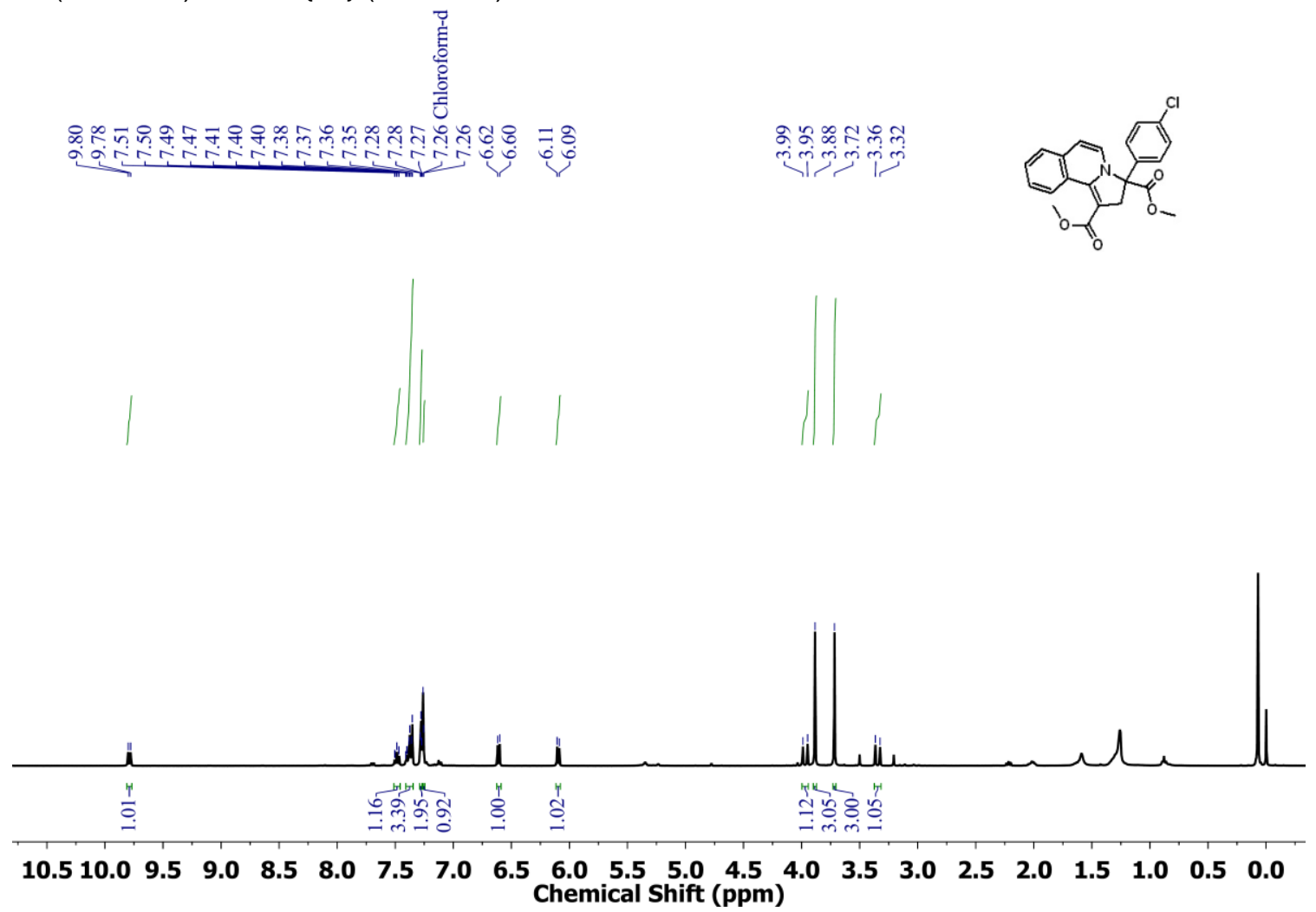

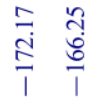
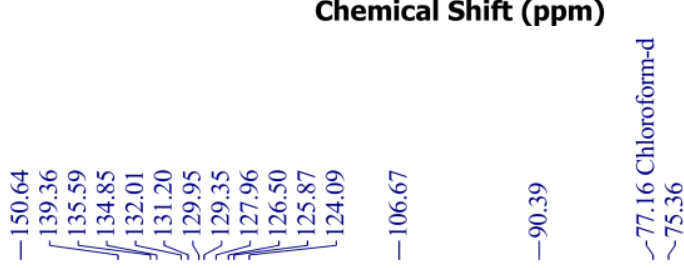

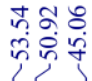
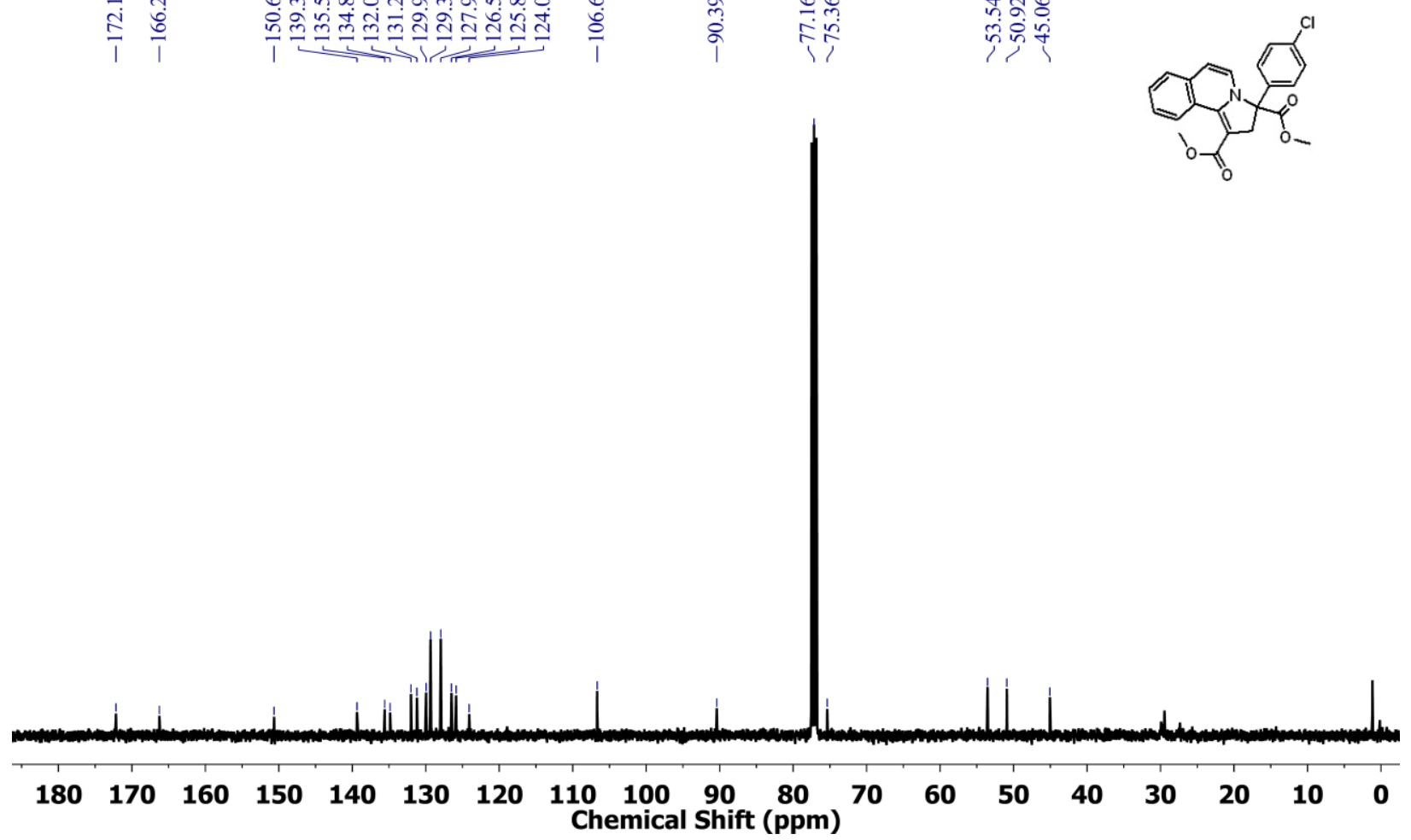
${ }^{1} \mathrm{H}(400 \mathrm{MHz}),{ }^{13} \mathrm{C}\left\{{ }^{1} \mathrm{H}\right\}(100 \mathrm{MHz})$ and ${ }^{19} \mathrm{~F}(376 \mathrm{MHz}) \mathrm{NMR}$ of $8 \mathrm{~g}$ in $\mathrm{CDCl}_{3}$ :
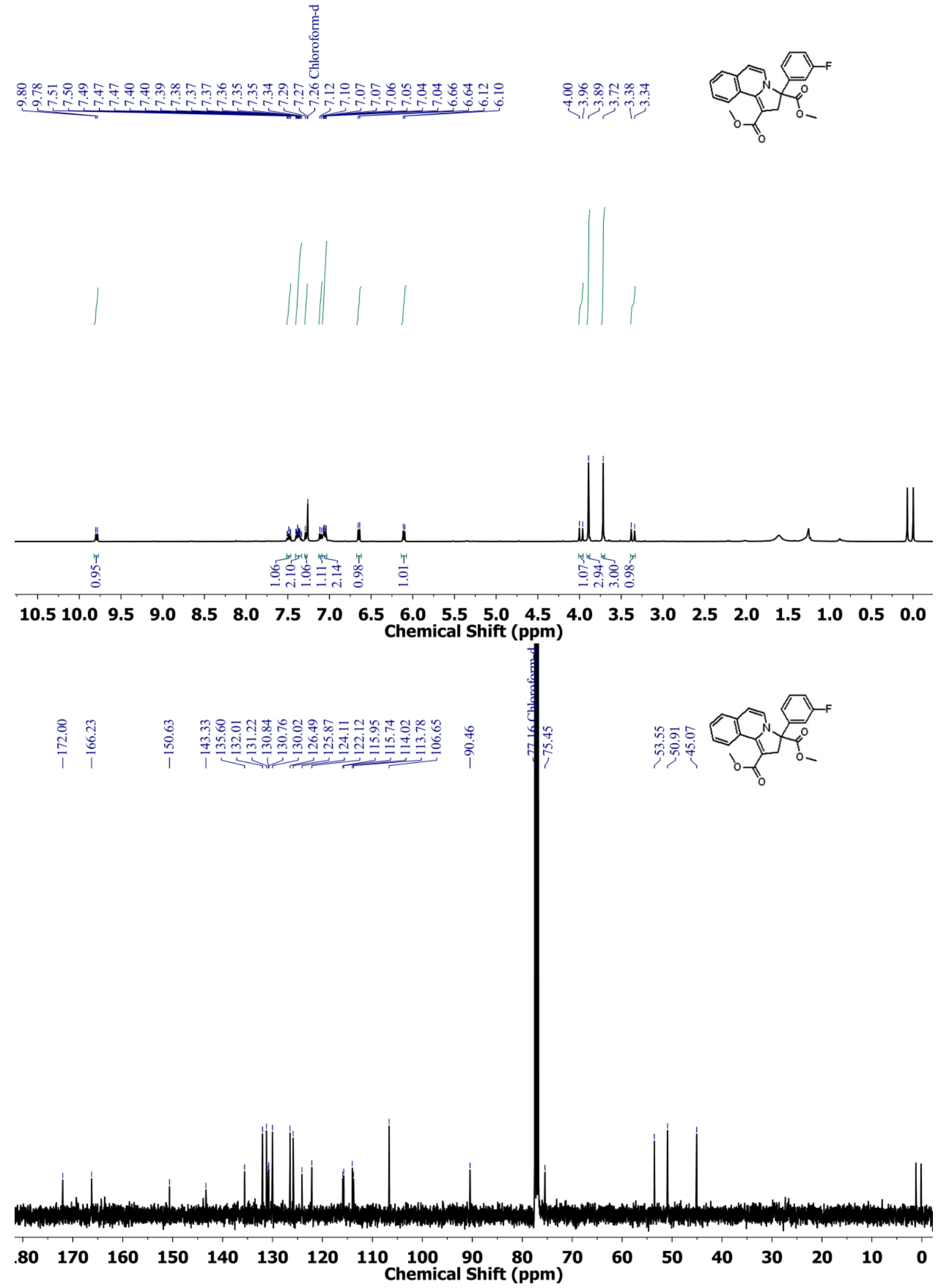

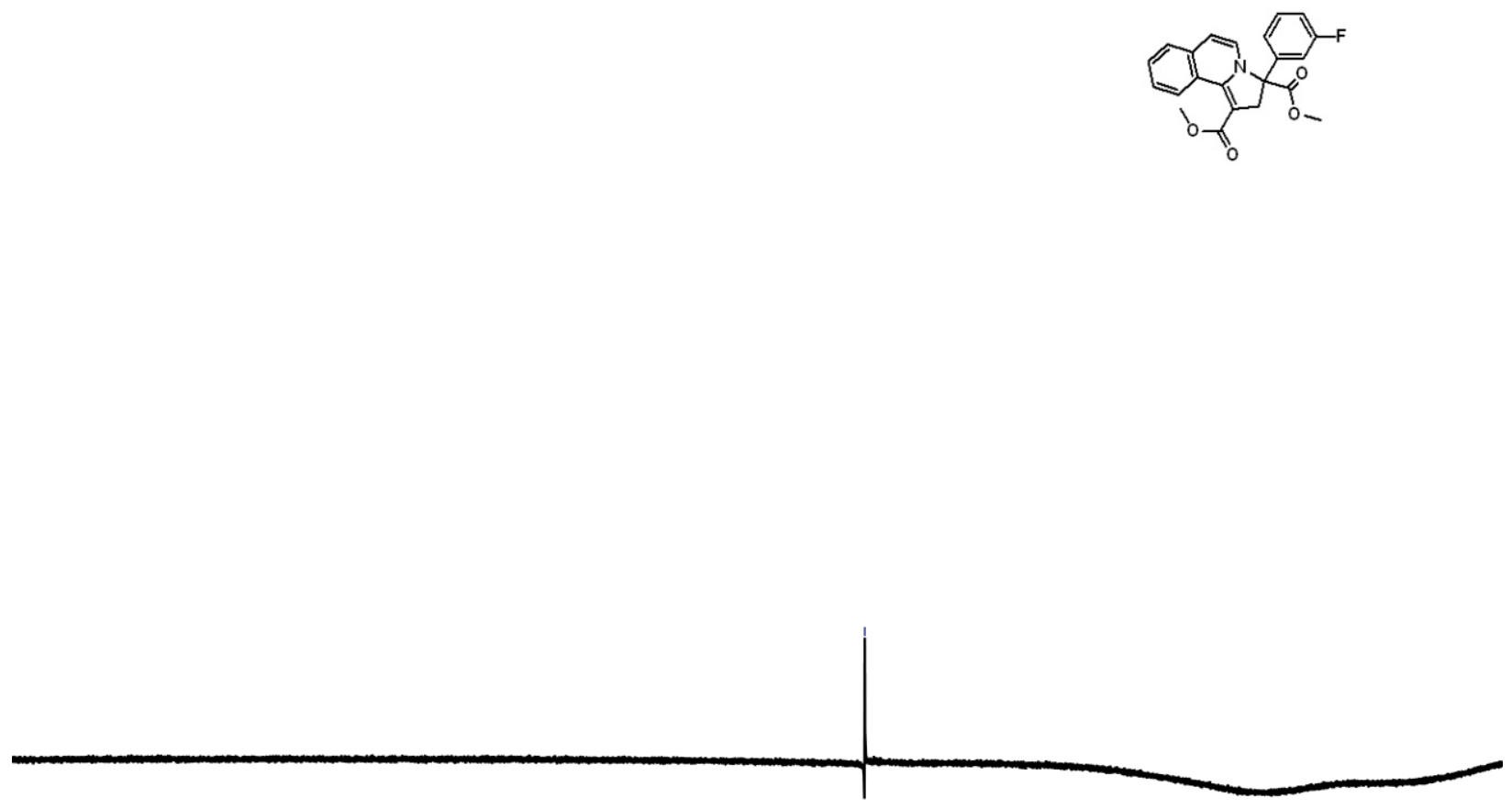

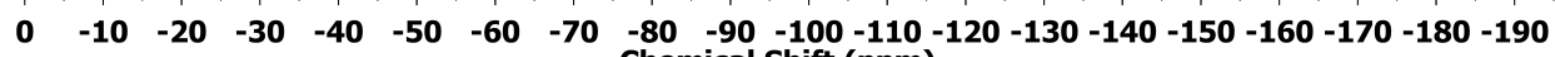
Chemical Shift (ppm) 
${ }^{1} \mathrm{H}(400 \mathrm{MHz})$ and ${ }^{13} \mathrm{C}\left\{{ }^{1} \mathrm{H}\right\}(100 \mathrm{MHz}) \mathrm{NMR}$ of $8 \mathbf{h}$ in $\mathrm{CDCl}_{3}$ :

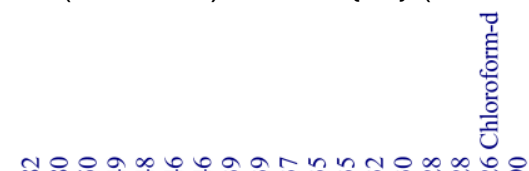

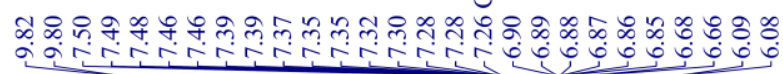

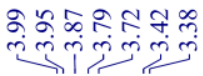
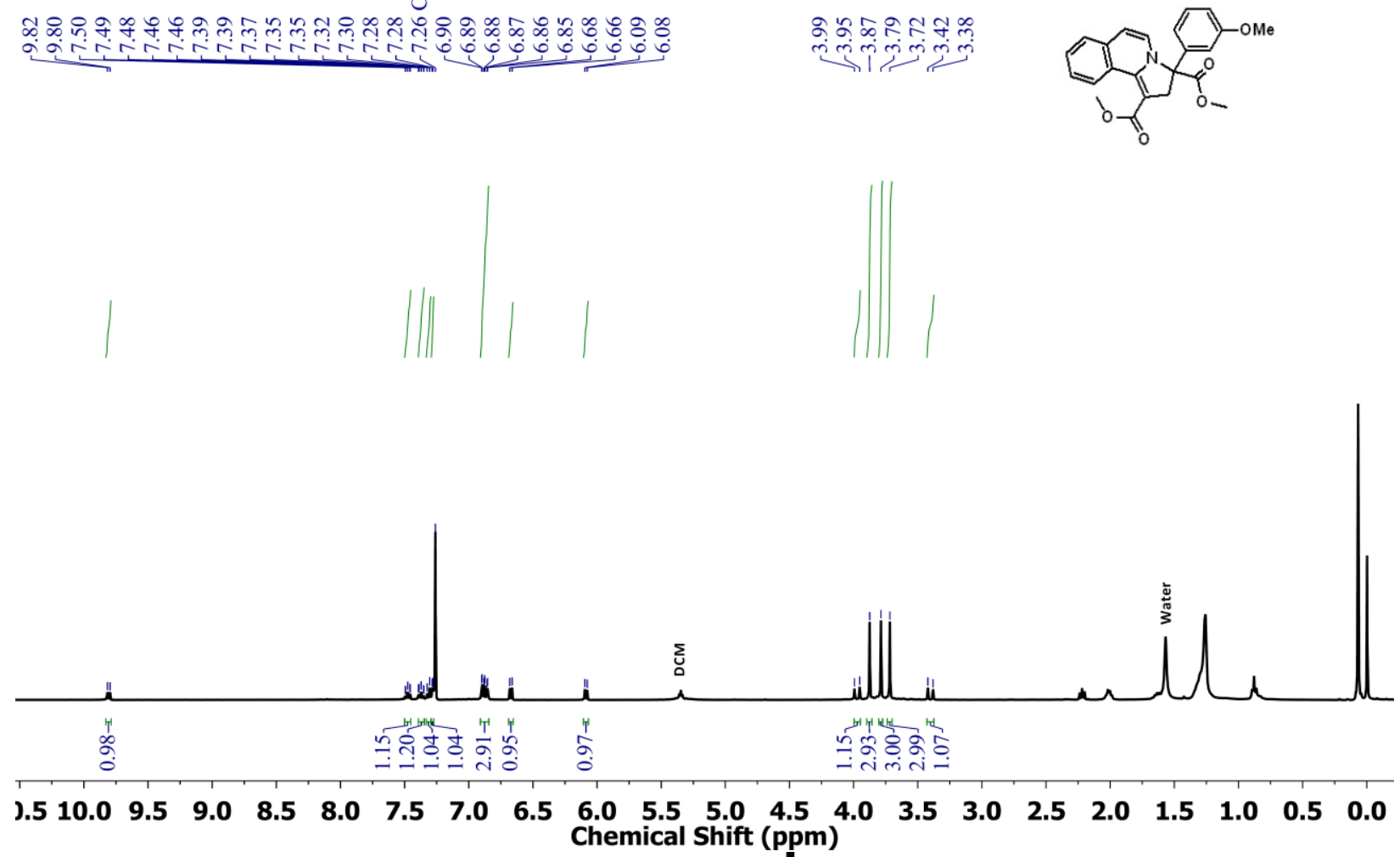

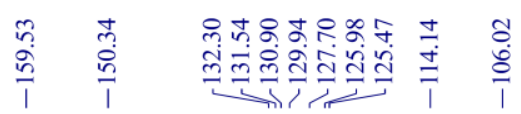

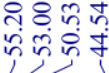
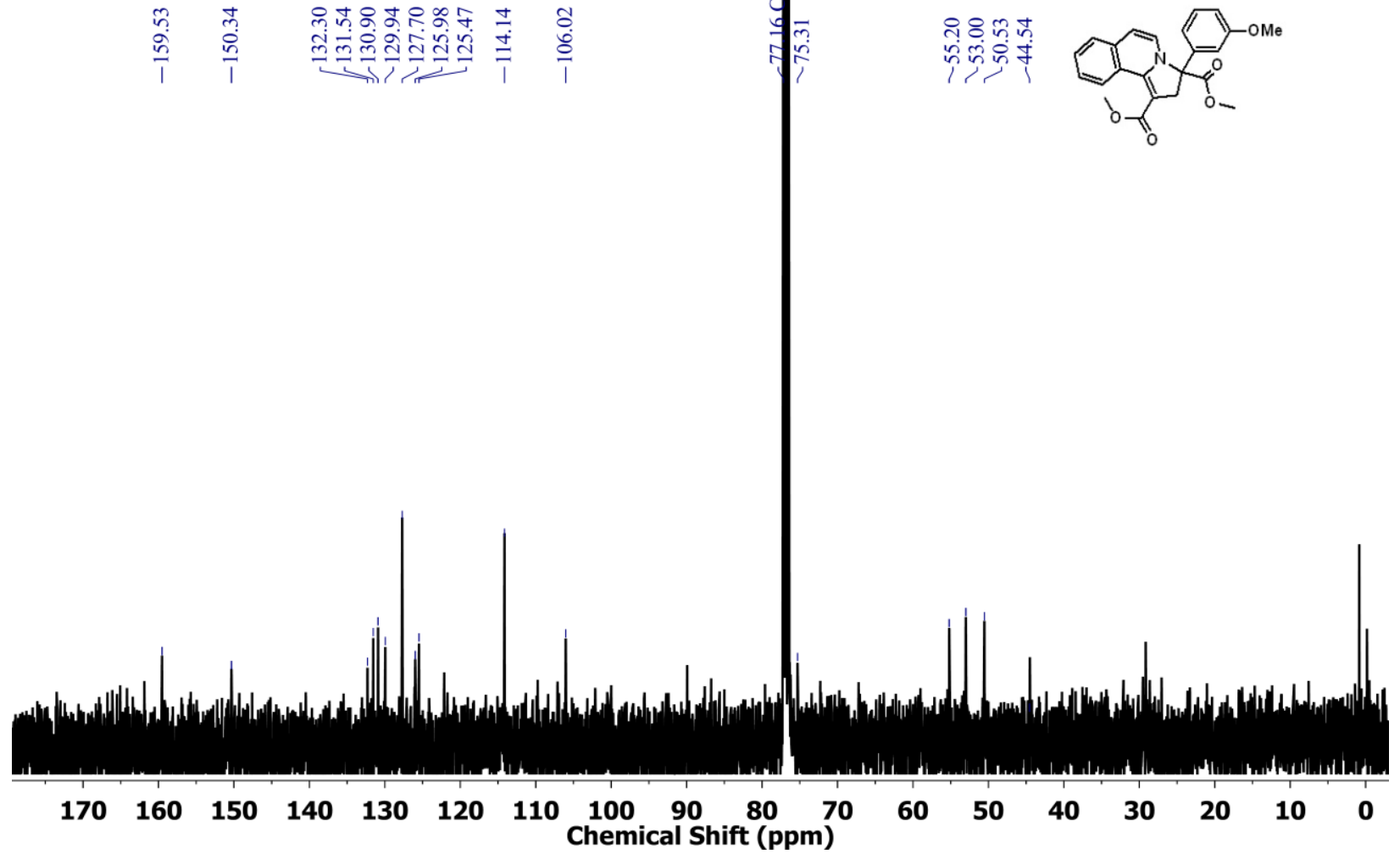
${ }^{1} \mathrm{H}(400 \mathrm{MHz})$ and ${ }^{13} \mathrm{C}\left\{{ }^{1} \mathrm{H}\right\}(100 \mathrm{MHz}) \mathrm{NMR}$ of $8 \mathbf{j}$ in $\mathrm{CDCl}_{3}$ :
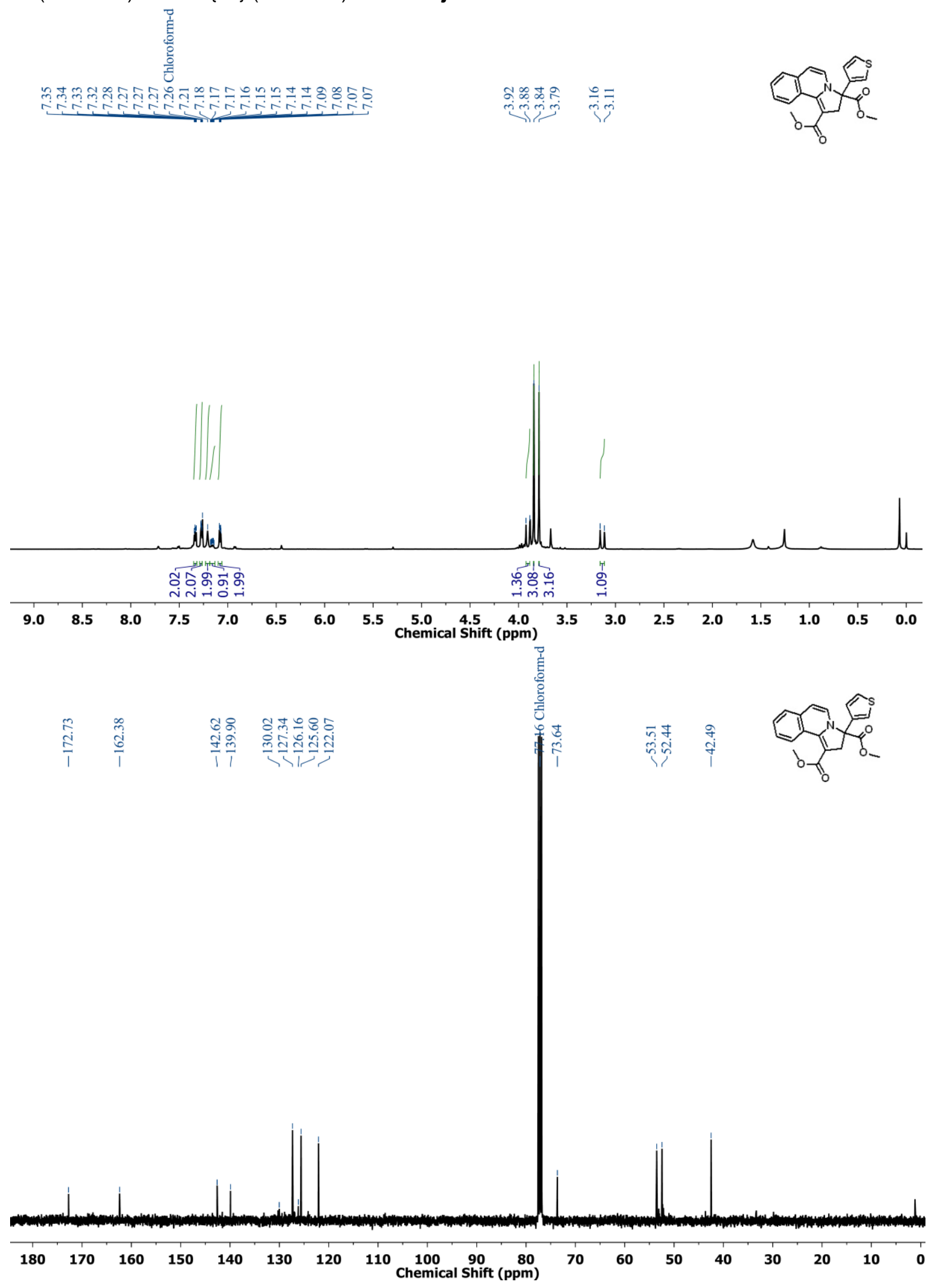
${ }^{1} \mathrm{H}(400 \mathrm{MHz})$ and ${ }^{13} \mathrm{C}\left\{{ }^{1} \mathrm{H}\right\}(100 \mathrm{MHz}) \mathrm{NMR}$ of $8 \mathbf{k}$ in $\mathrm{CDCl}_{3}$ :
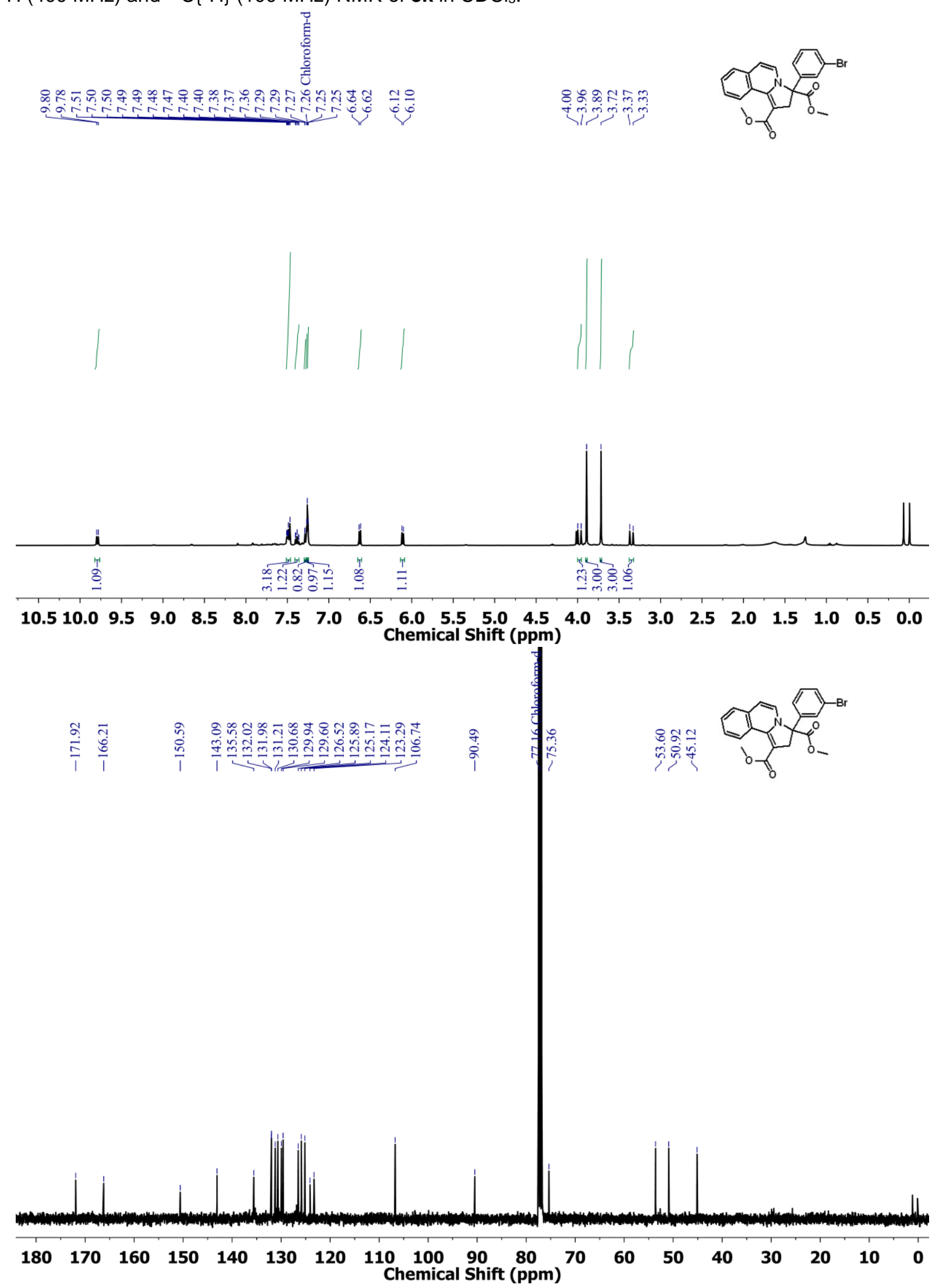
${ }^{1} \mathrm{H}(400 \mathrm{MHz})$ and ${ }^{13} \mathrm{C}\left\{{ }^{1} \mathrm{H}\right\}(100 \mathrm{MHz}) \mathrm{NMR}$ of $8 \mathrm{I}$ in $\mathrm{CDCl}_{3}$ :
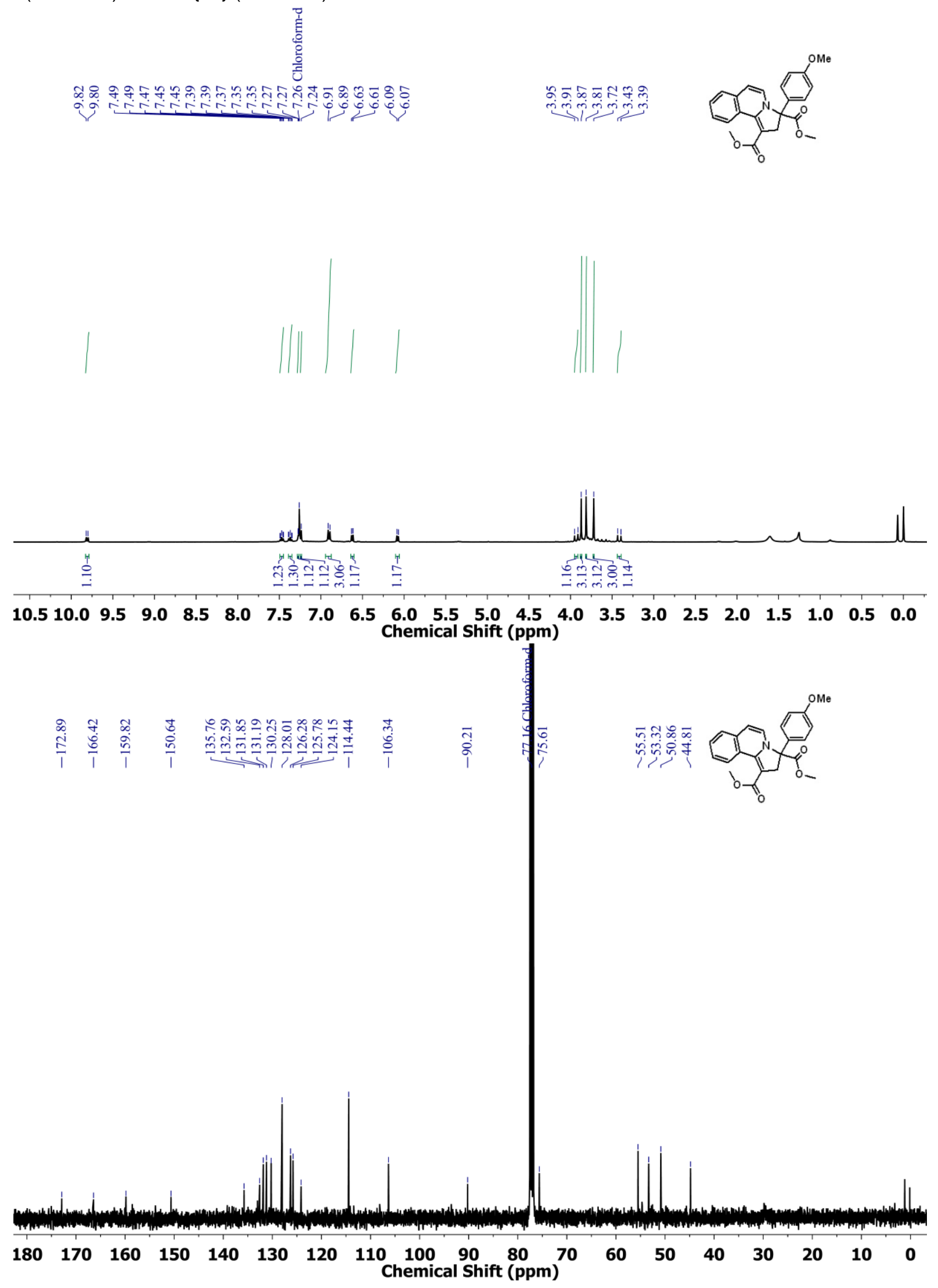
${ }^{1} \mathrm{H}(400 \mathrm{MHz})$ and ${ }^{13} \mathrm{C}\left\{{ }^{1} \mathrm{H}\right\}(100 \mathrm{MHz})$ NMR of 9 a in $\mathrm{CDCl}_{3}$ :
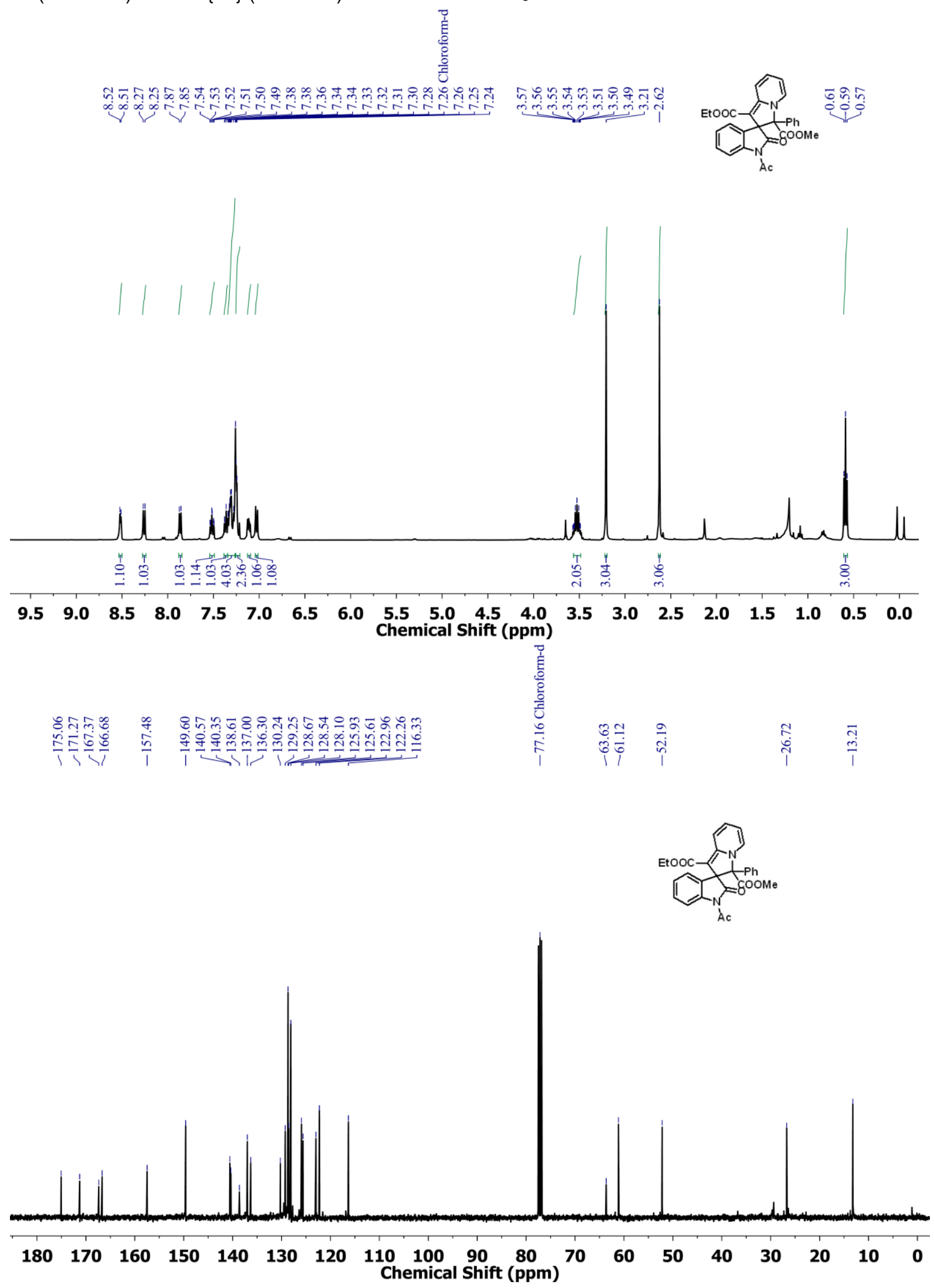
${ }^{1} \mathrm{H}(400 \mathrm{MHz})$ and ${ }^{13} \mathrm{C}\left\{{ }^{1} \mathrm{H}\right\}(100 \mathrm{MHz}) \mathrm{NMR}$ of $9 \mathbf{b}$ in $\mathrm{CDCl}_{3}$ :
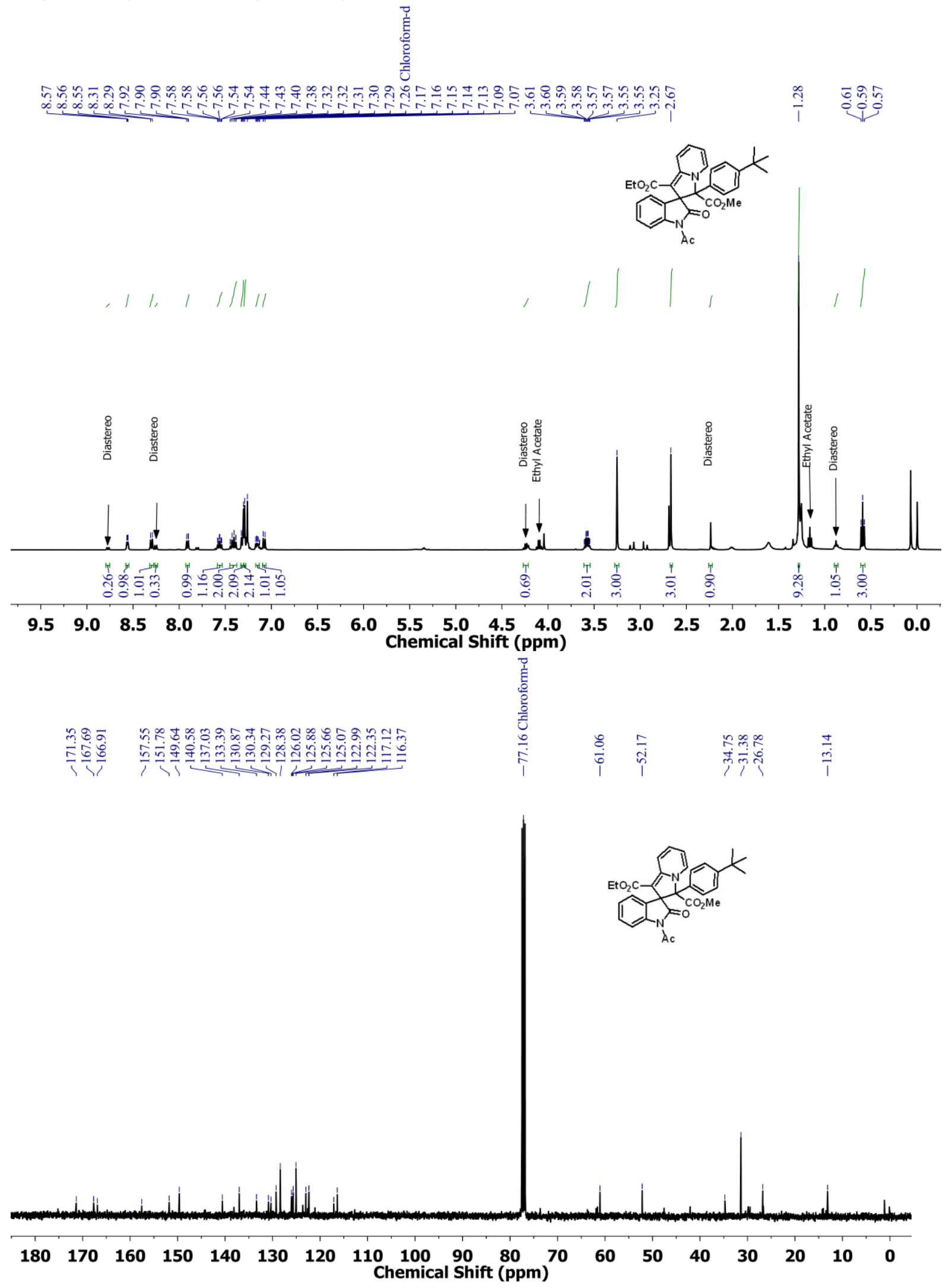
${ }^{1} \mathrm{H}(400 \mathrm{MHz})$ and ${ }^{13} \mathrm{C}\left\{{ }^{1} \mathrm{H}\right\}(100 \mathrm{MHz}) \mathrm{NMR}$ of $9 \mathrm{c}$ in $\mathrm{CDCl}_{3}$ :
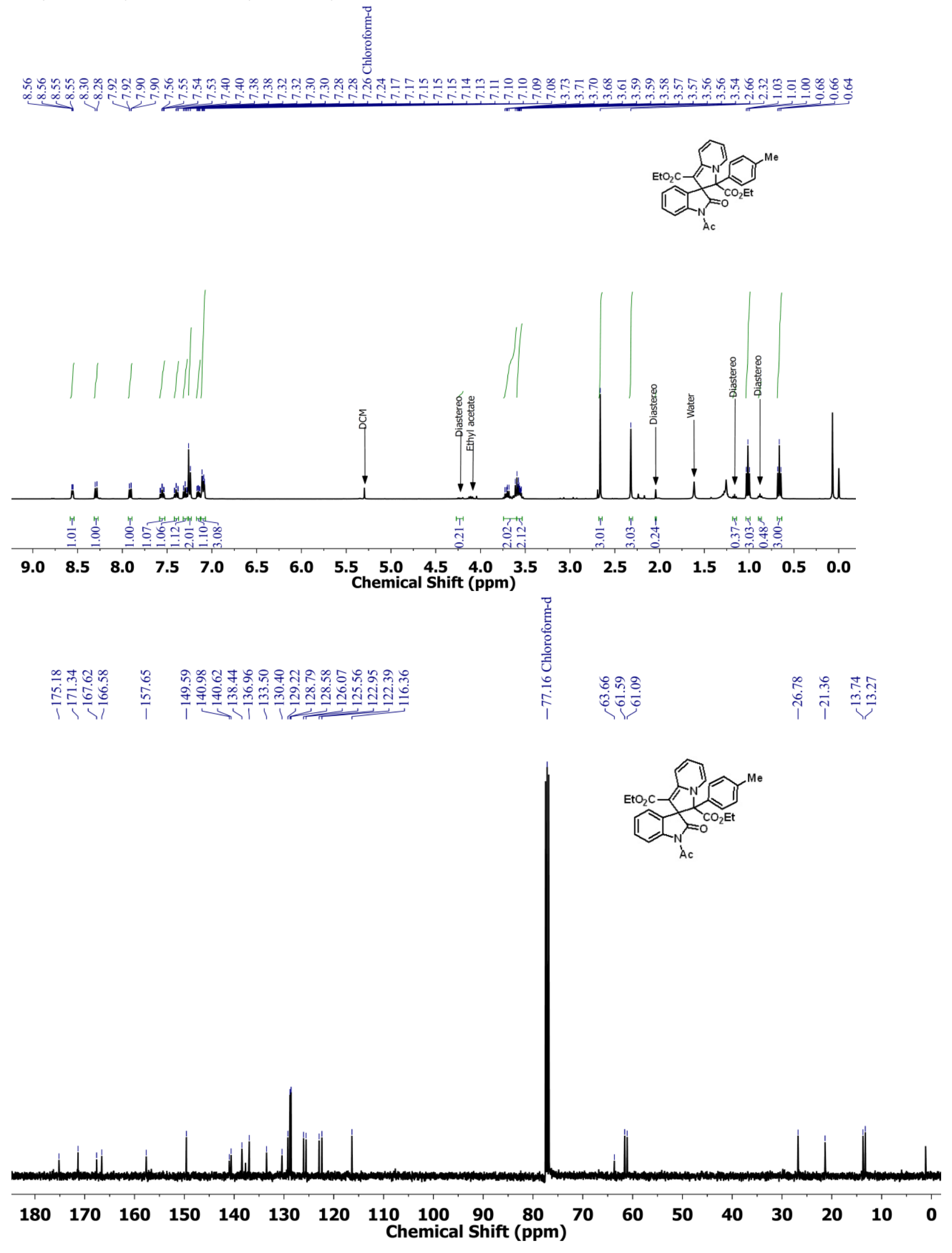
${ }^{1} \mathrm{H}(400 \mathrm{MHz})$ and ${ }^{13} \mathrm{C}\left\{{ }^{1} \mathrm{H}\right\}(100 \mathrm{MHz}) \mathrm{NMR}$ of $\mathbf{9 d}$ in $\mathrm{CDCl}_{3}$ :
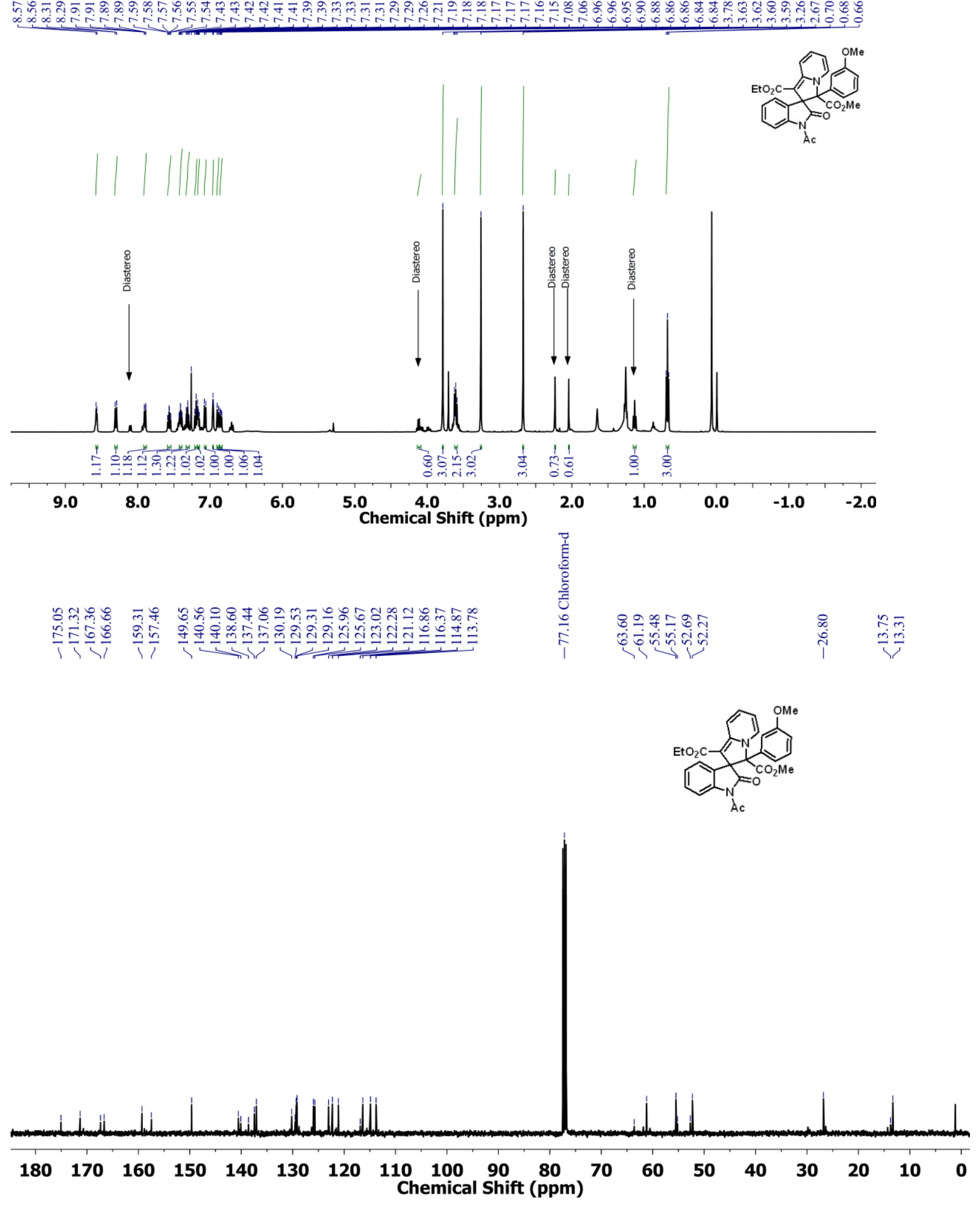
${ }^{1} \mathrm{H}(400 \mathrm{MHz})$ and ${ }^{13} \mathrm{C}\left\{{ }^{1} \mathrm{H}\right\}(100 \mathrm{MHz}) \mathrm{NMR}$ of $9 \mathrm{e}$ in $\mathrm{CDCl}_{3}$ :
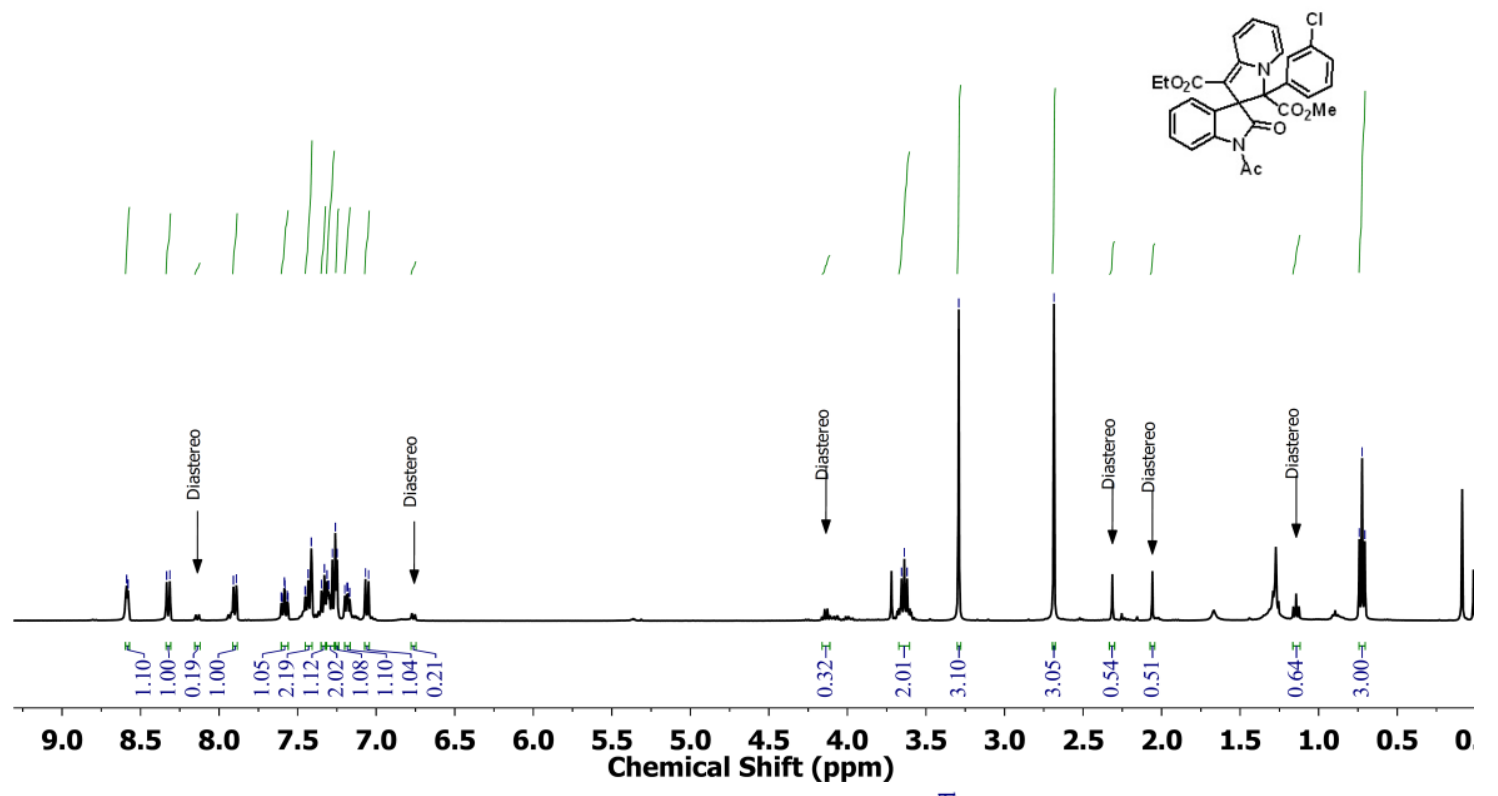

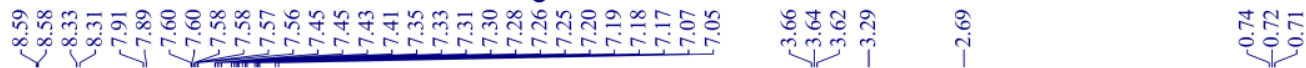

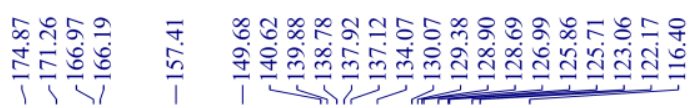
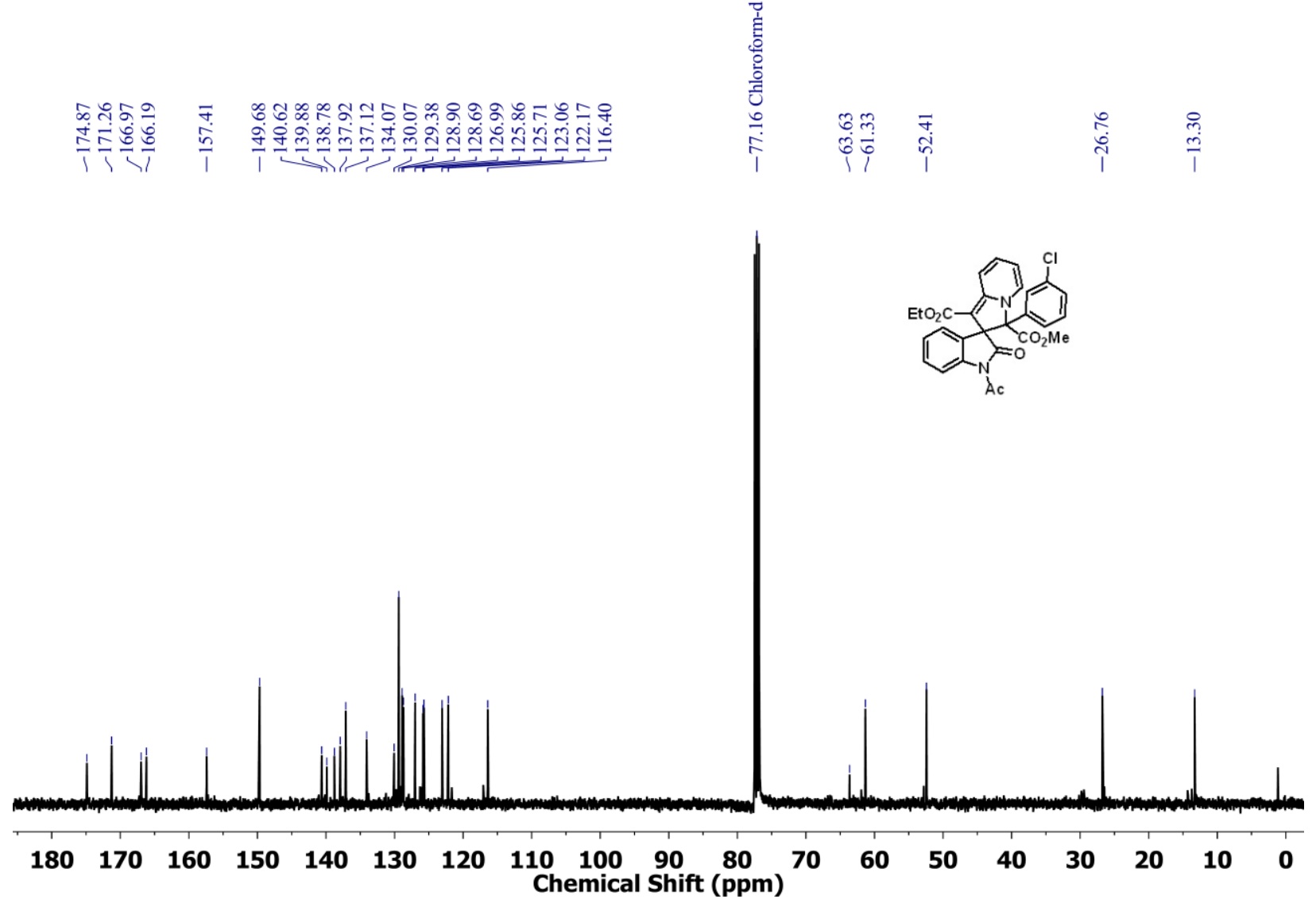
${ }^{1} \mathrm{H}(400 \mathrm{MHz})$ and ${ }^{13} \mathrm{C}\left\{{ }^{1} \mathrm{H}\right\}(100 \mathrm{MHz})$ NMR of $9 \mathrm{f}$ in $\mathrm{CDCl}_{3}$ :
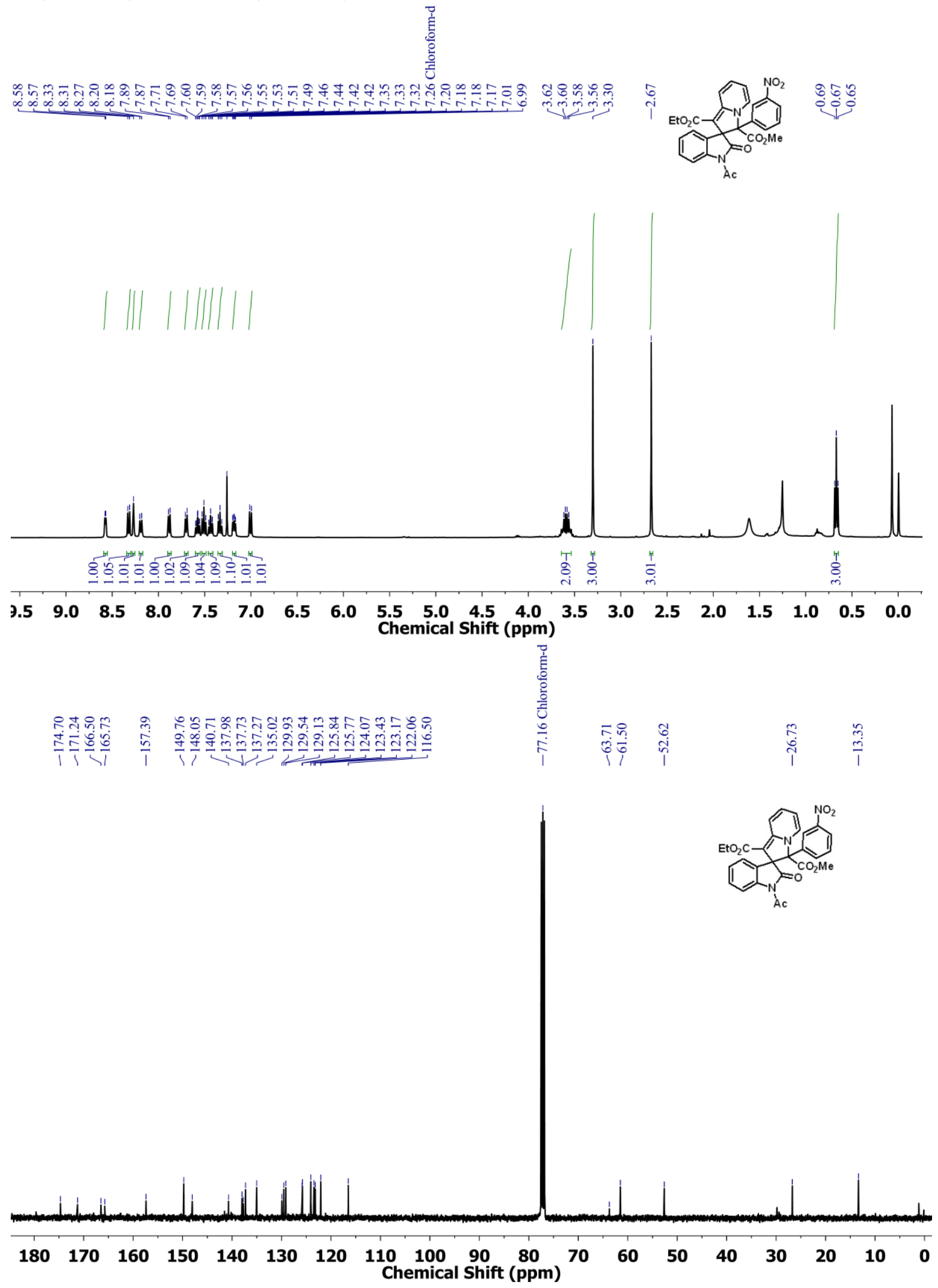
${ }^{1} \mathrm{H}(400 \mathrm{MHz})$ and ${ }^{13} \mathrm{C}\left\{{ }^{1} \mathrm{H}\right\}(100 \mathrm{MHz}) \mathrm{NMR}$ of $9 \mathrm{~g}$ in $\mathrm{CDCl}_{3}$ :
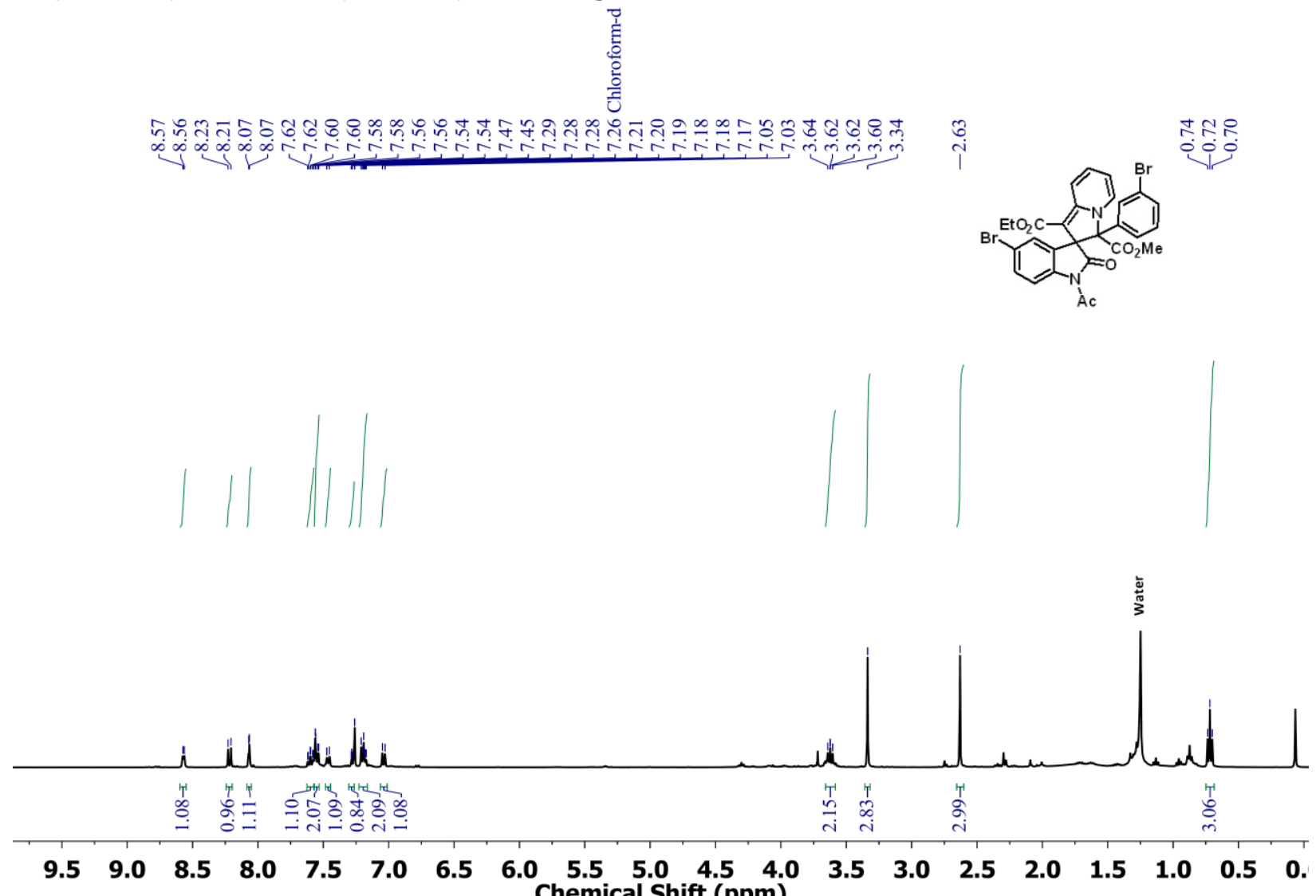

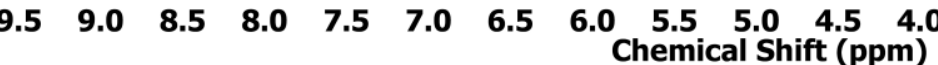
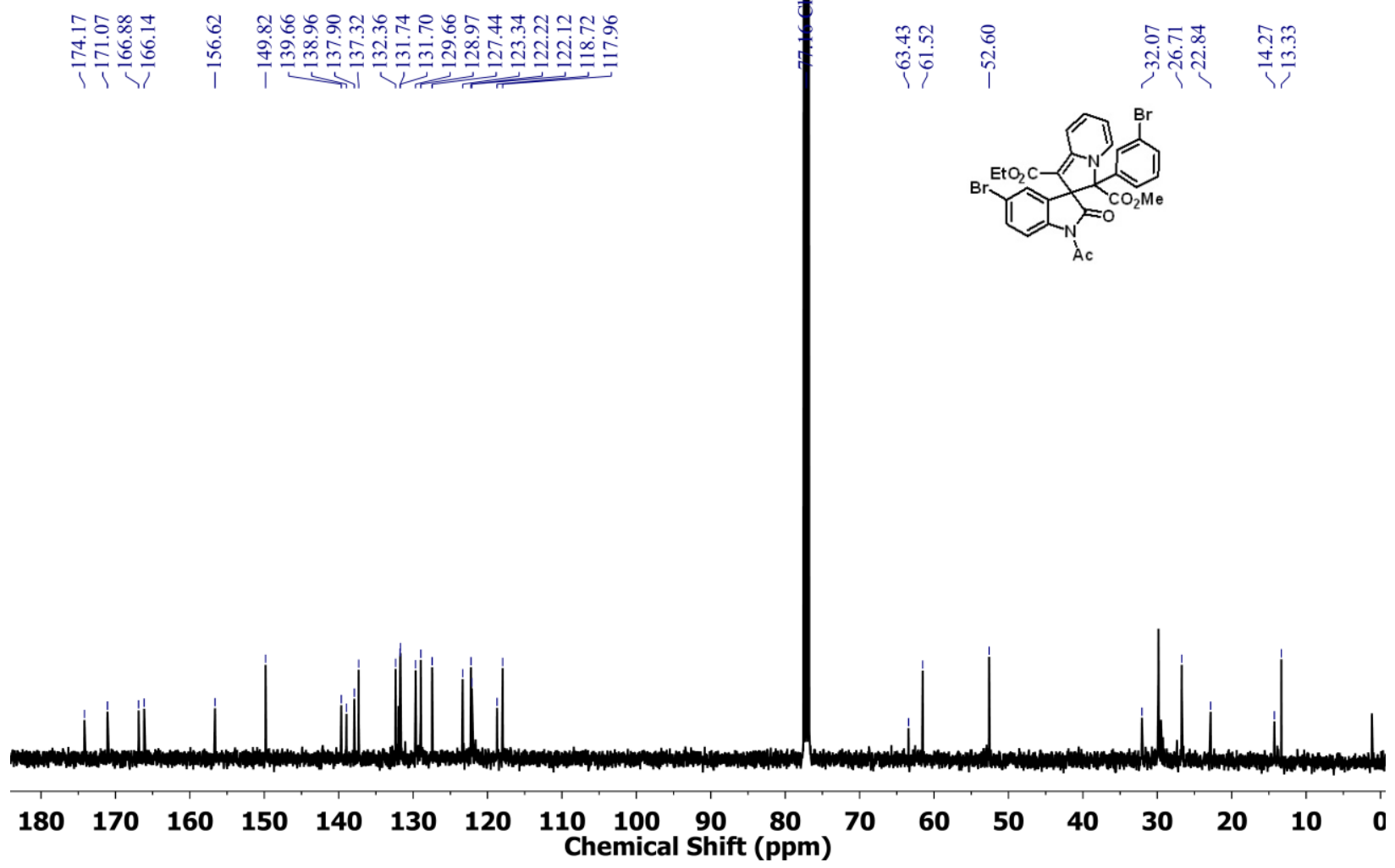
${ }^{1} \mathrm{H}(400 \mathrm{MHz})$ and ${ }^{13} \mathrm{C}\left\{{ }^{1} \mathrm{H}\right\}(100 \mathrm{MHz}) \mathrm{NMR}$ of $9 \mathbf{h}$ in $\mathrm{CDCl}_{3}$ :

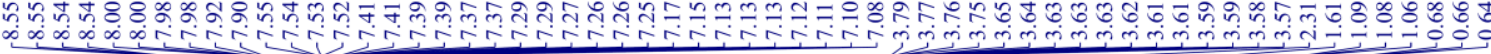

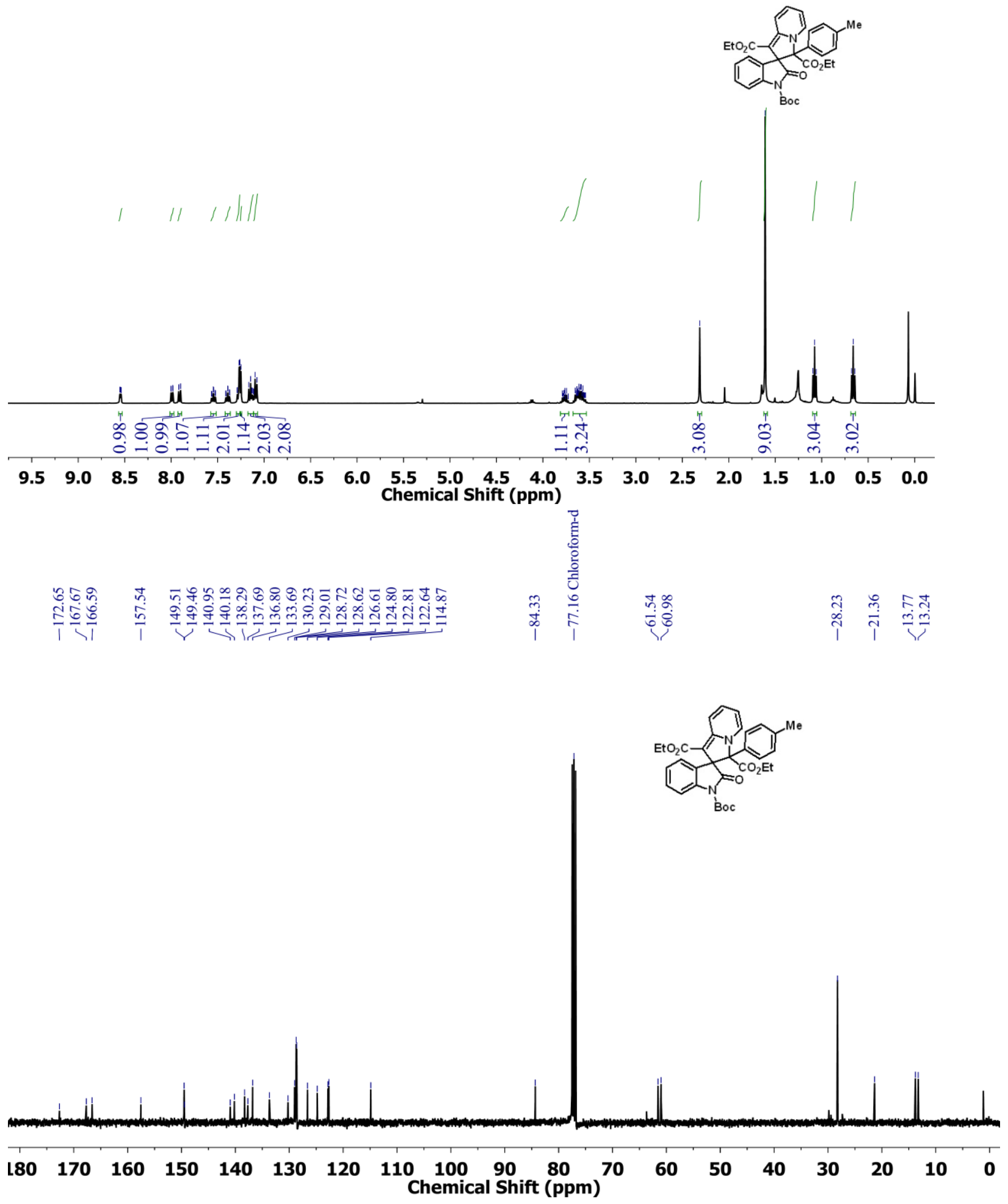


${ }^{1} \mathrm{H}(400 \mathrm{MHz})$ and ${ }^{13} \mathrm{C}\left\{{ }^{1} \mathrm{H}\right\}(100 \mathrm{MHz}) \mathrm{NMR}$ of $9 \mathrm{i}$ in $\mathrm{CDCl}_{3}$ :

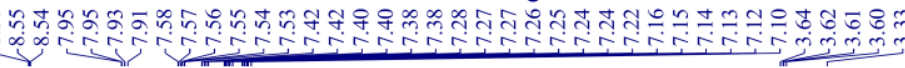

$$
\text { i. }
$$
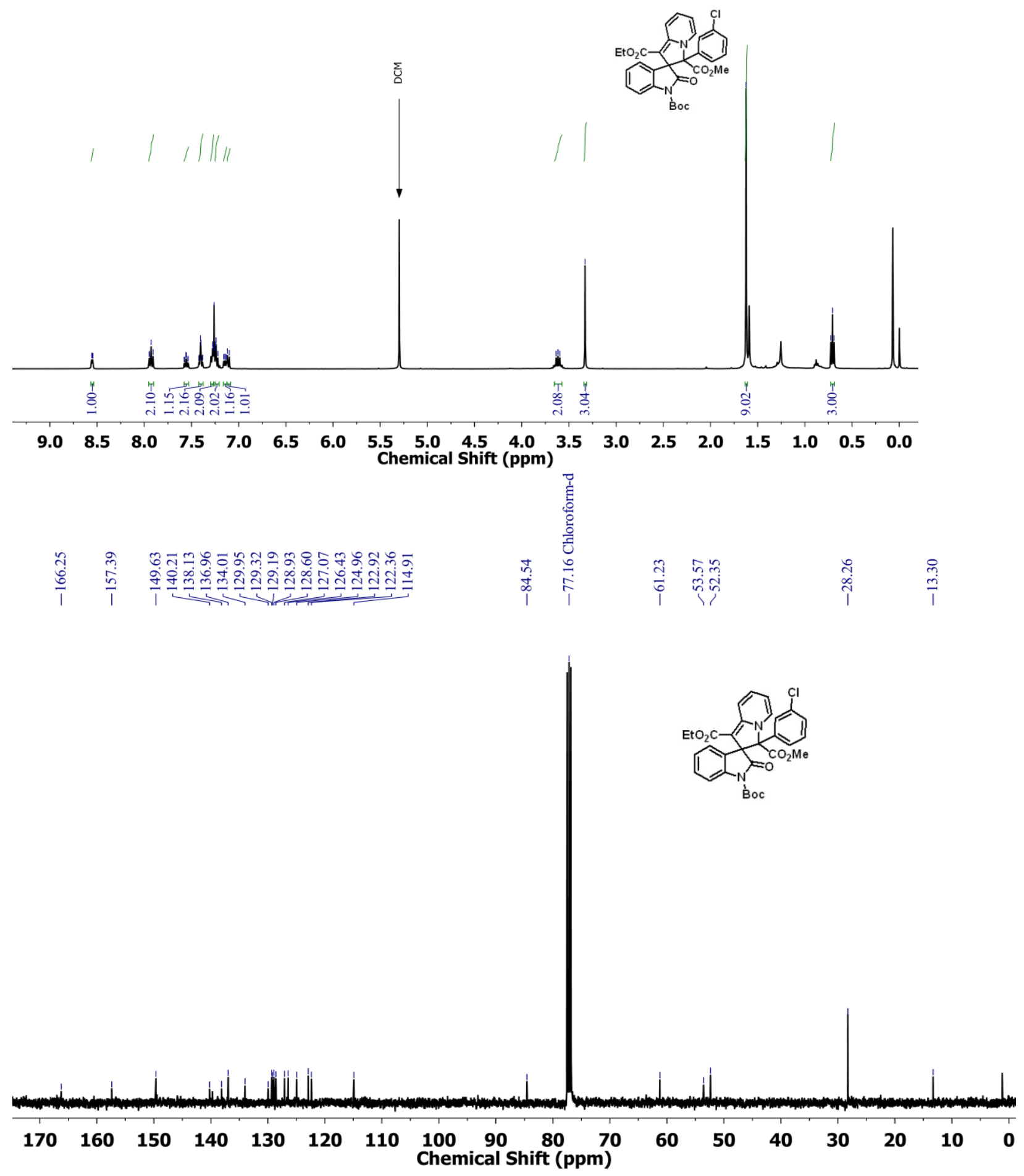
${ }^{1} \mathrm{H}(400 \mathrm{MHz})$ and ${ }^{13} \mathrm{C}\left\{{ }^{1} \mathrm{H}\right\}(100 \mathrm{MHz}) \mathrm{NMR}$ of $9 \mathrm{j}$ in $\mathrm{CDCl}_{3}$ :

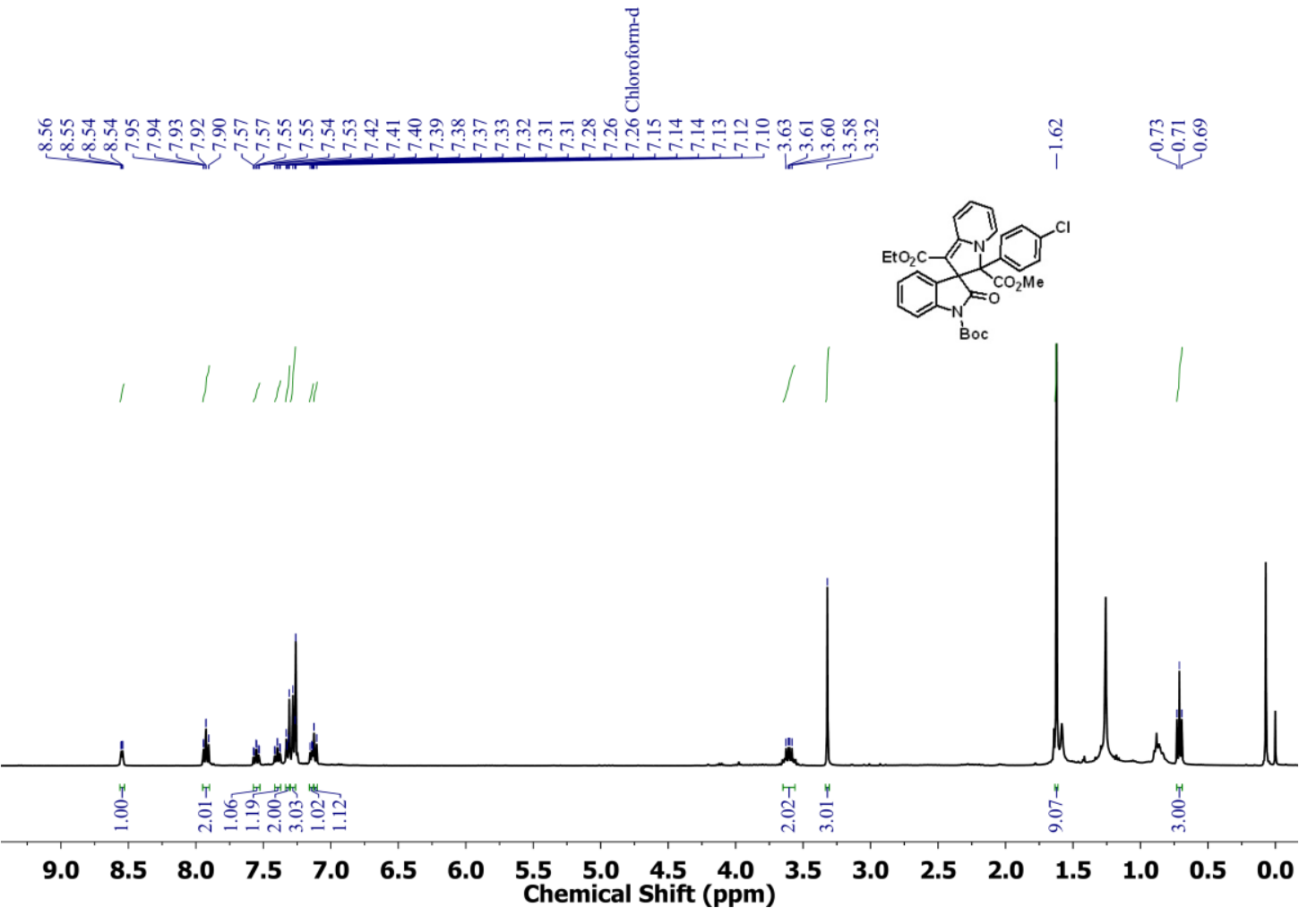

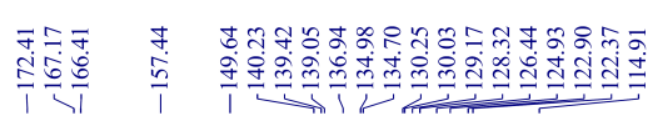
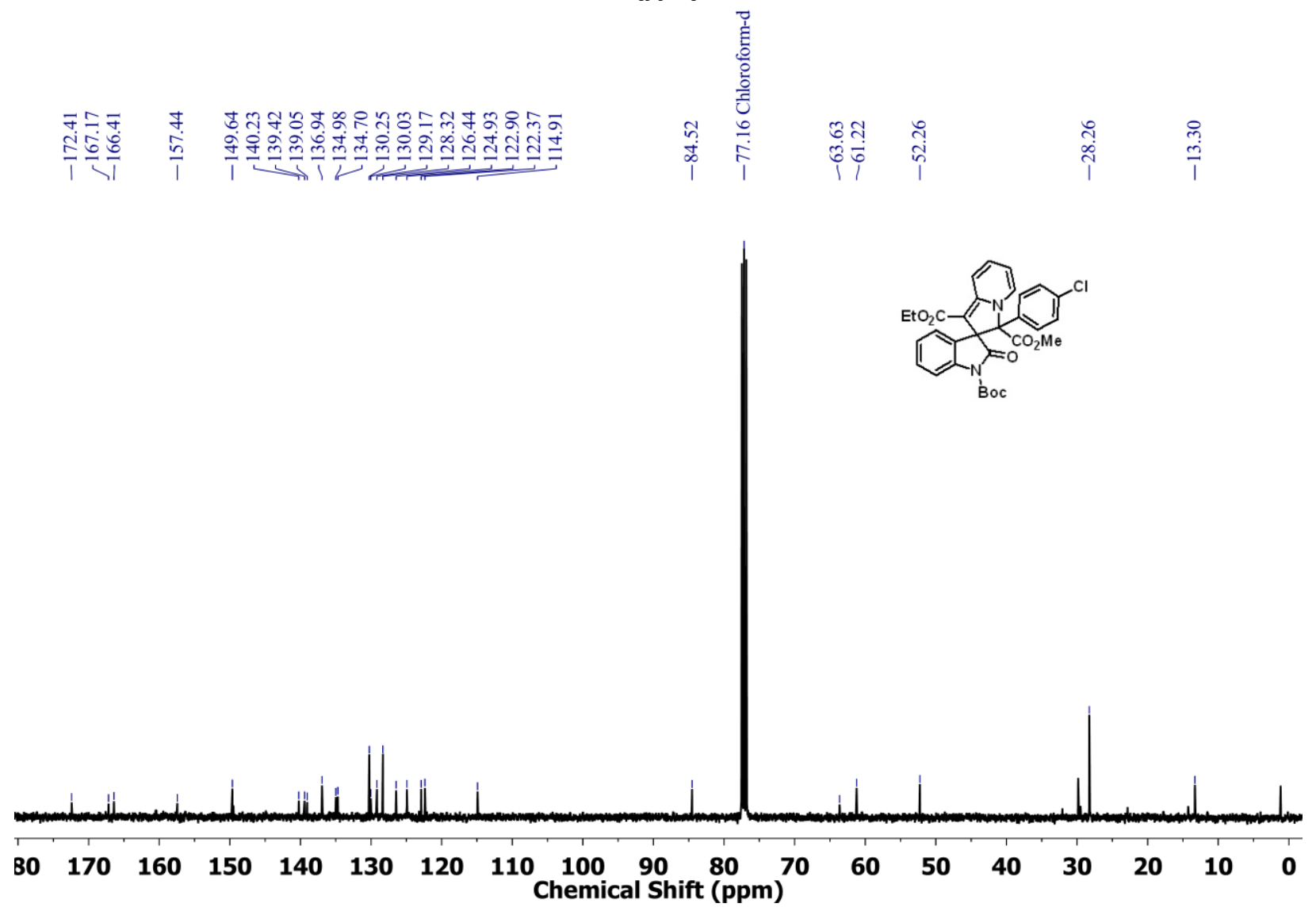
${ }^{1} \mathrm{H}(400 \mathrm{MHz})$ and ${ }^{13} \mathrm{C}\left\{{ }^{1} \mathrm{H}\right\}(100 \mathrm{MHz}) \mathrm{NMR}$ of $9 \mathbf{k}$ in $\mathrm{CDCl}_{3}$ :

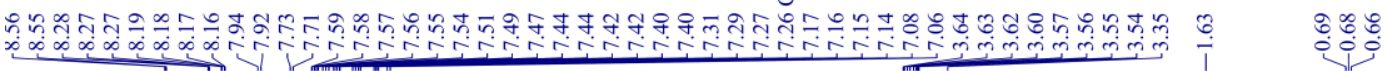

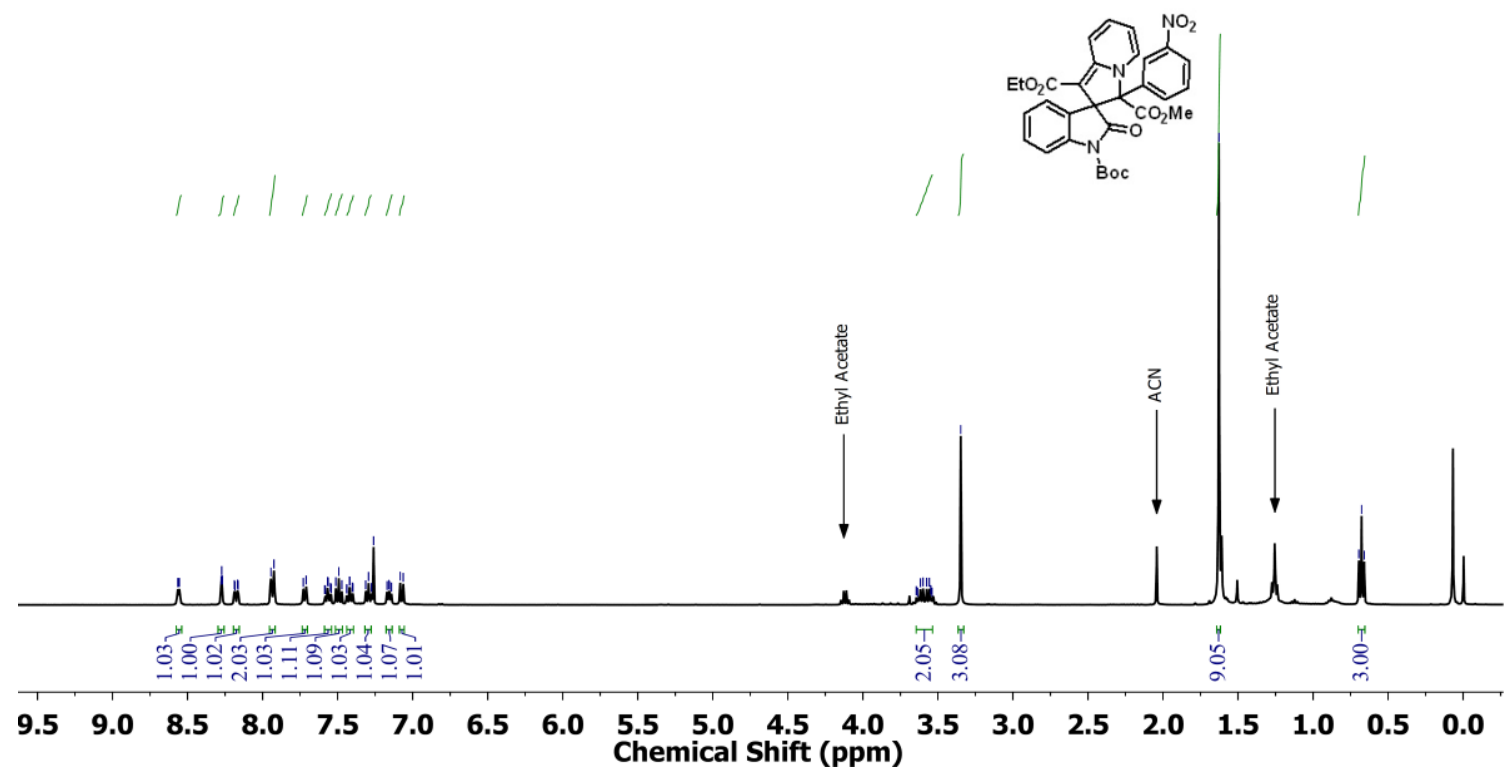

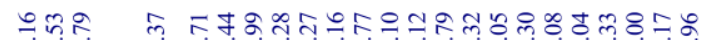

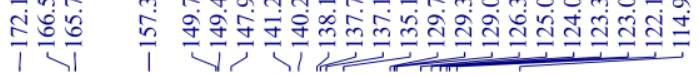

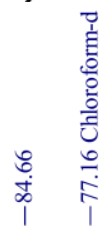

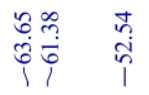

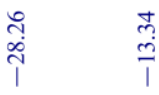

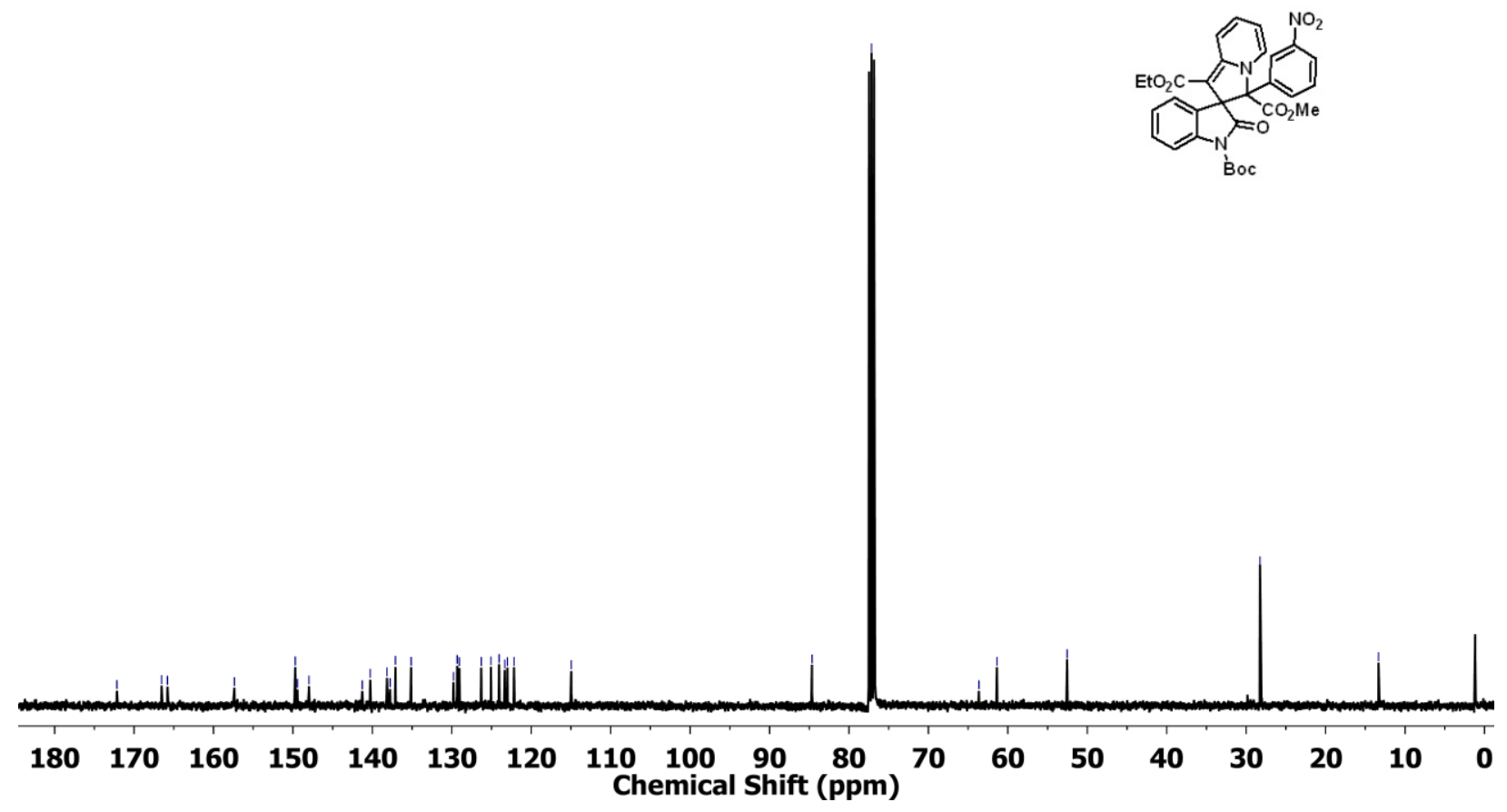


${ }^{1} \mathrm{H}(400 \mathrm{MHz})$ and ${ }^{13} \mathrm{C}\left\{{ }^{1} \mathrm{H}\right\}(100 \mathrm{MHz})$ NMR of $10 \mathrm{a}$ in $\mathrm{CDCl}_{3}$ :

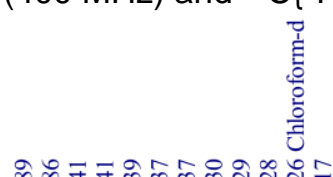

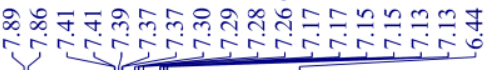

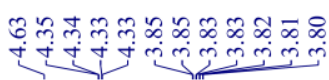

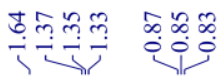
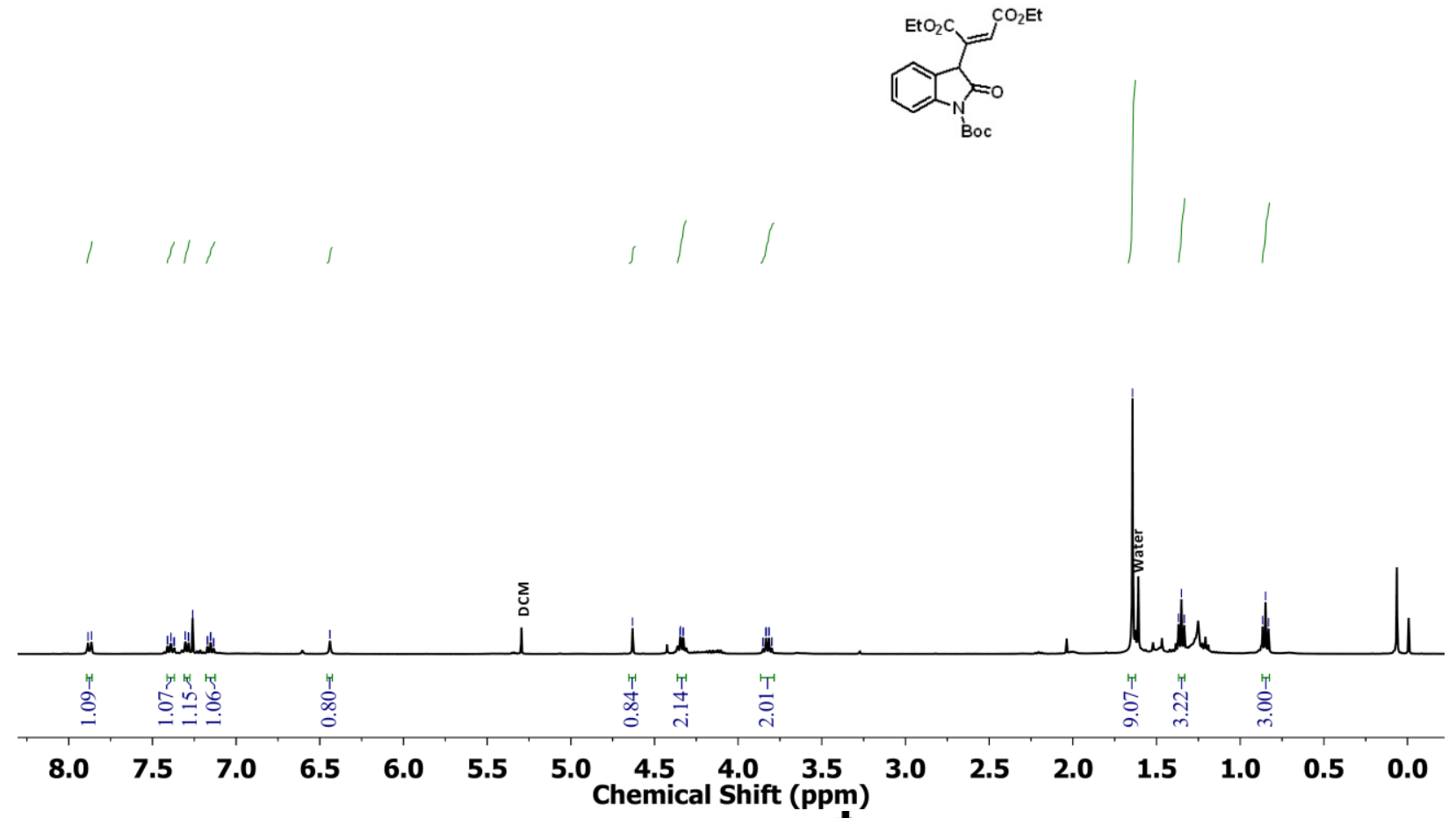

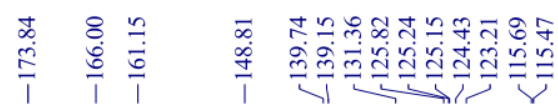
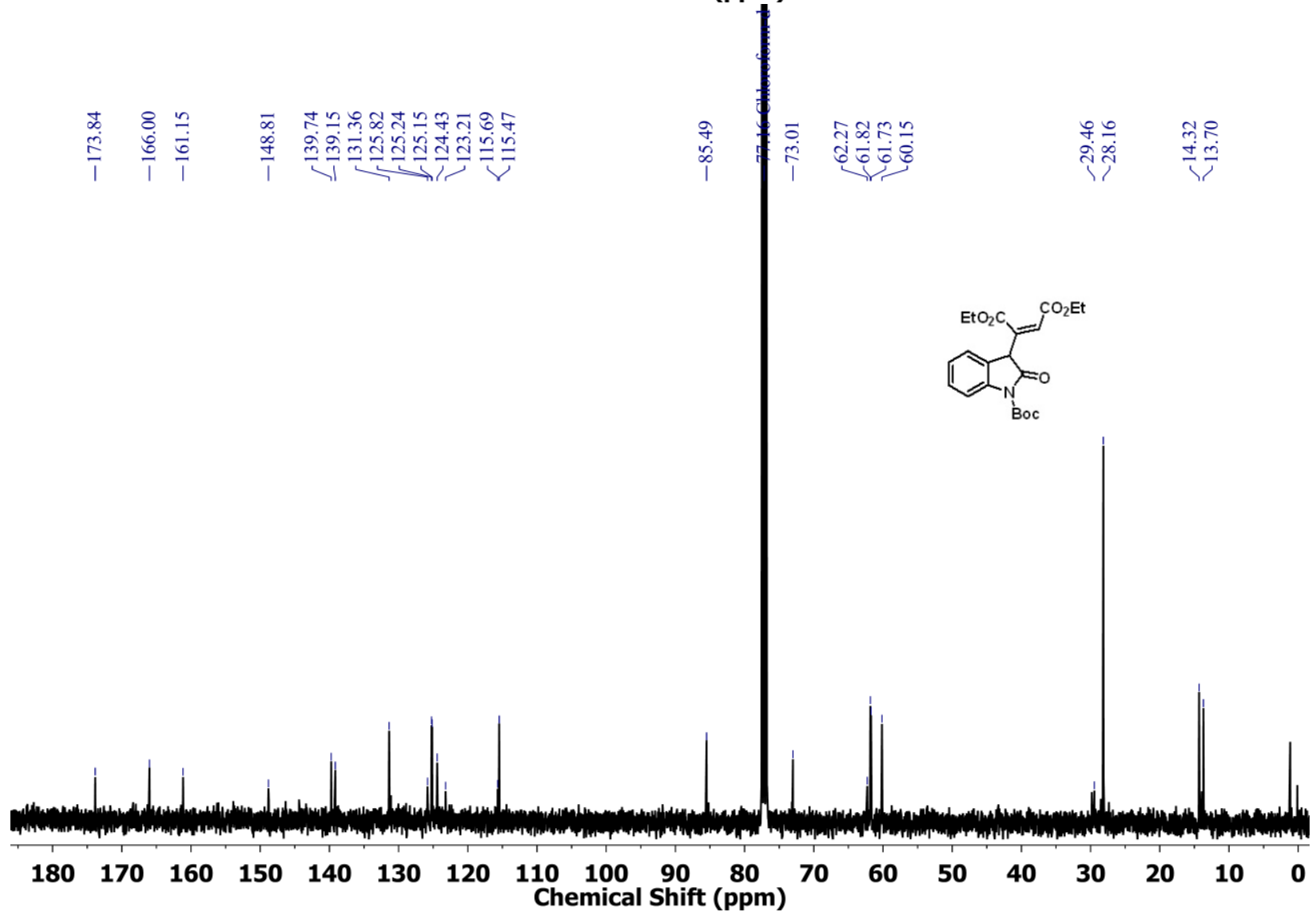
${ }^{1} \mathrm{H}(400 \mathrm{MHz})$ and ${ }^{13} \mathrm{C}\left\{{ }^{1} \mathrm{H}\right\}(100 \mathrm{MHz})$ NMR of $10 \mathrm{~b}$ in $\mathrm{CDCl}_{3}$ :
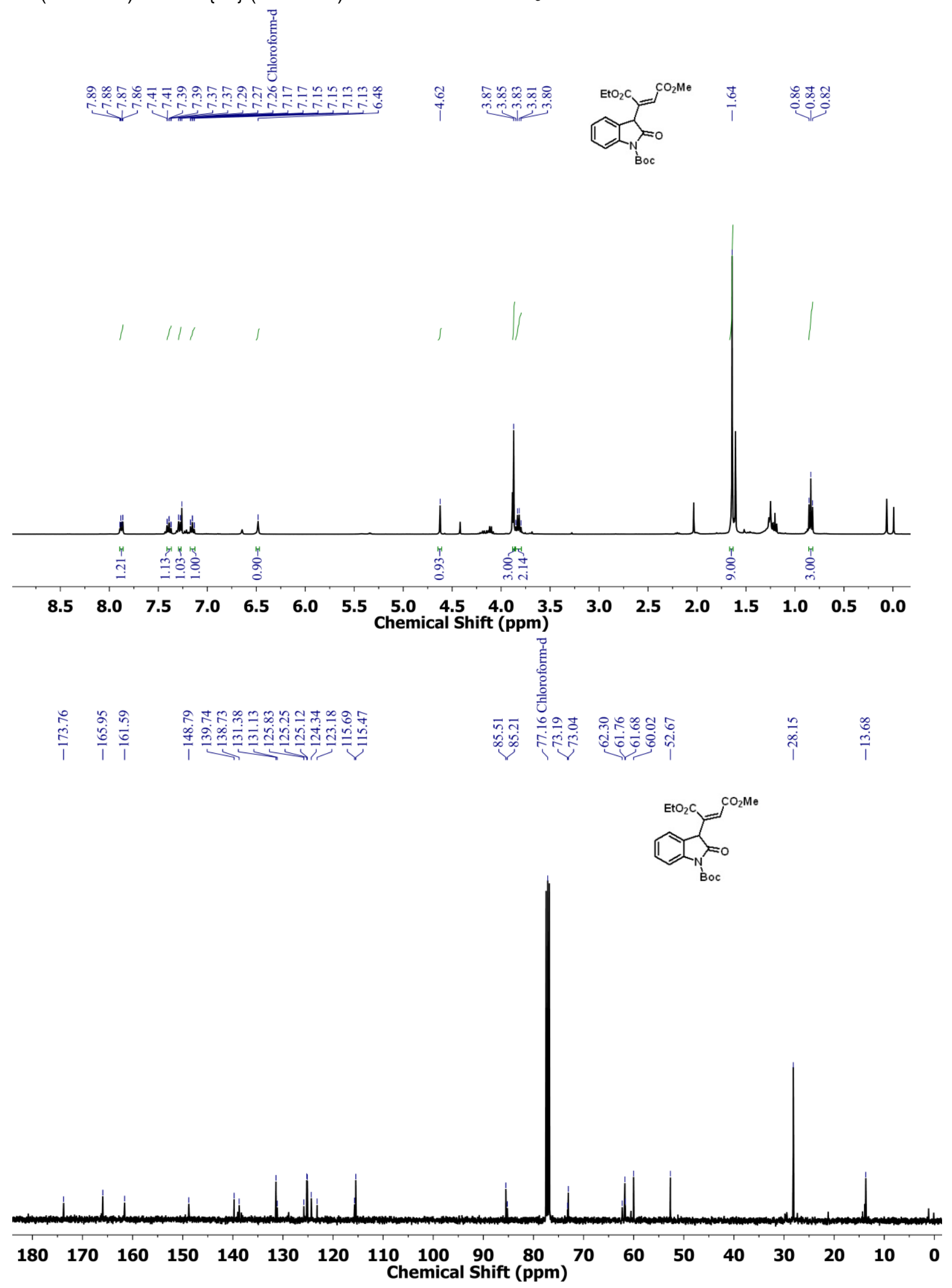
${ }^{1} \mathrm{H}(400 \mathrm{MHz})$ and ${ }^{13} \mathrm{C}\left\{{ }^{1} \mathrm{H}\right\}(100 \mathrm{MHz})$ NMR of Phosphonium ylide in $\mathrm{CDCl}_{3}$ :
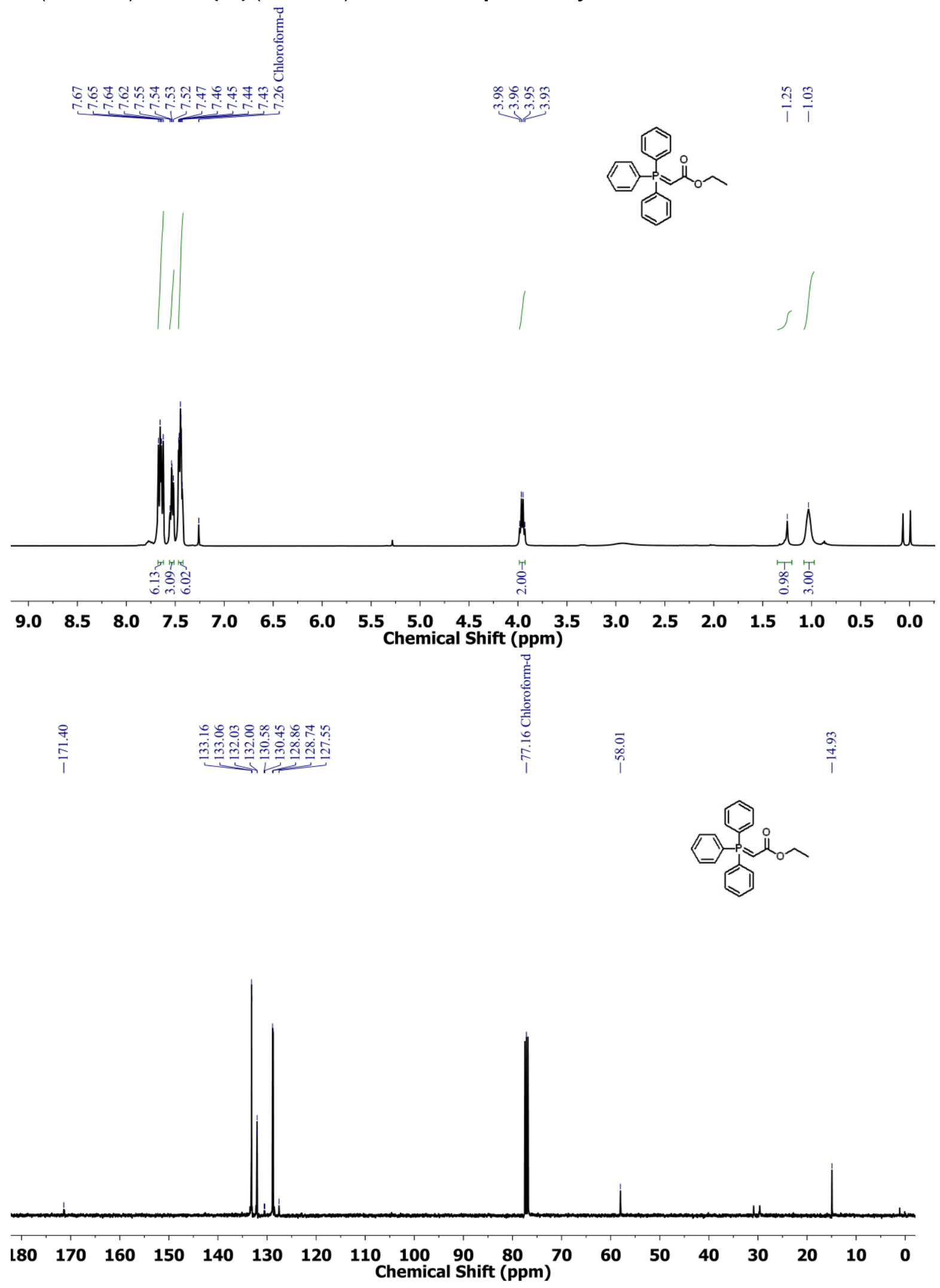
${ }^{1} \mathrm{H}(400 \mathrm{MHz})$ and ${ }^{13} \mathrm{C}\left\{{ }^{1} \mathrm{H}\right\}(100 \mathrm{MHz})$ NMR of Ethyl (E)-2-(2-oxoindolin-3-ylidene)acetate in $\mathrm{CDCl}_{3}$ :
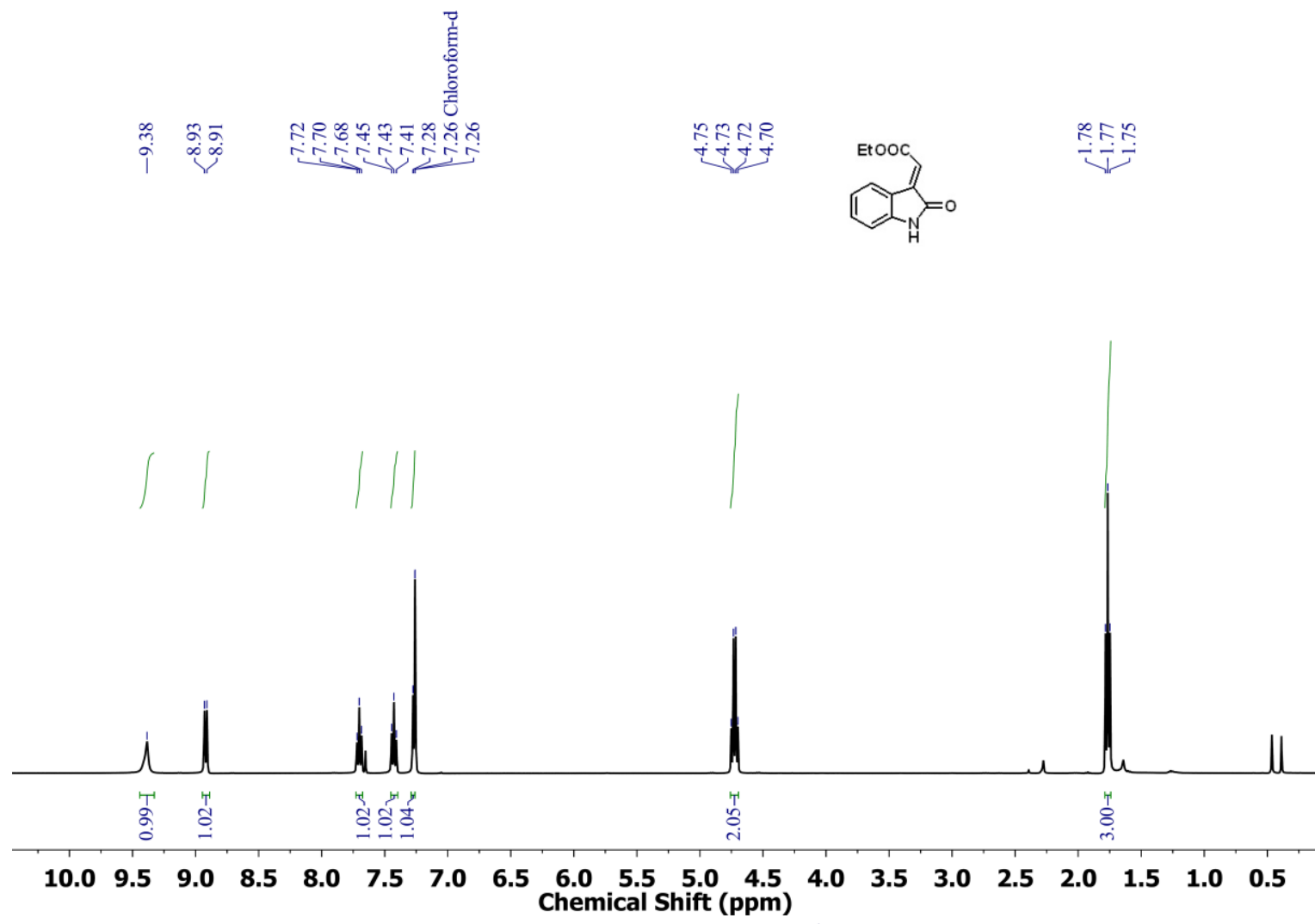

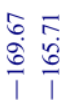

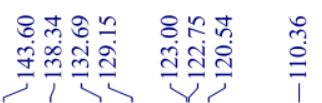
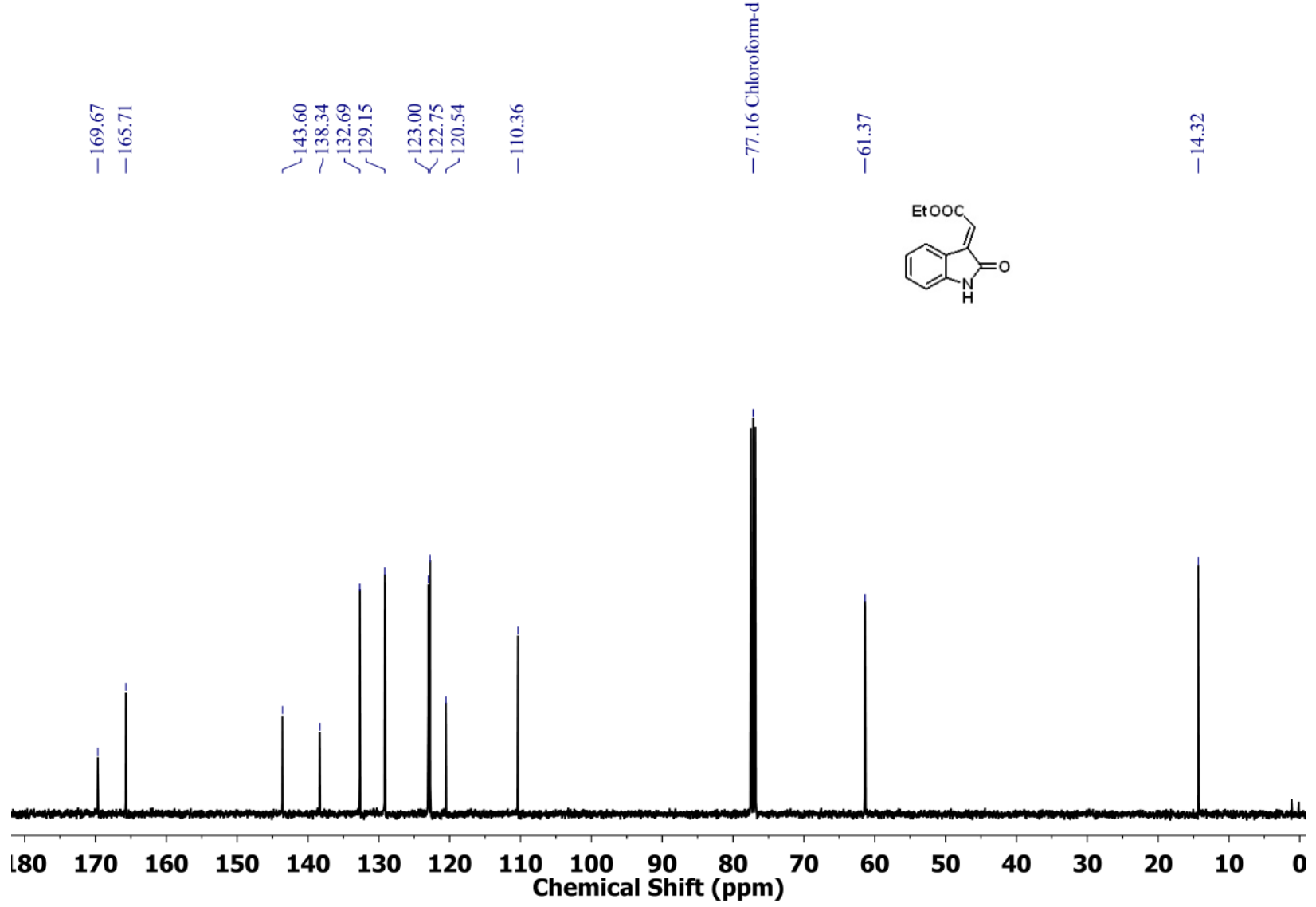
${ }^{1} \mathrm{H}(400 \mathrm{MHz})$ and ${ }^{13} \mathrm{C}\left\{{ }^{1} \mathrm{H}\right\}(100 \mathrm{MHz})$ NMR of $6 \mathbf{a}$ in $\mathrm{CDCl}_{3}$ :
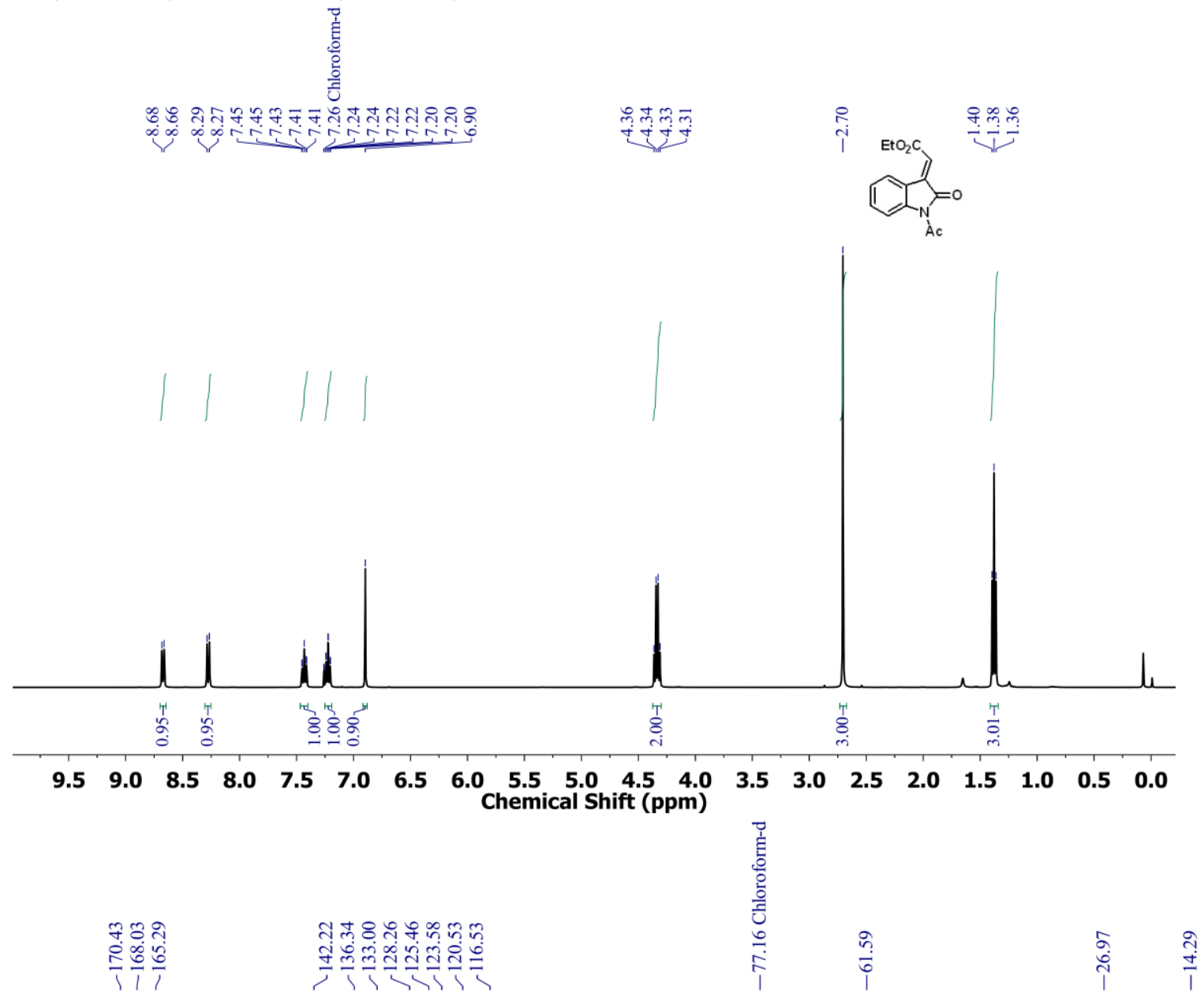

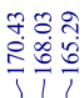

สิษ

ปั่
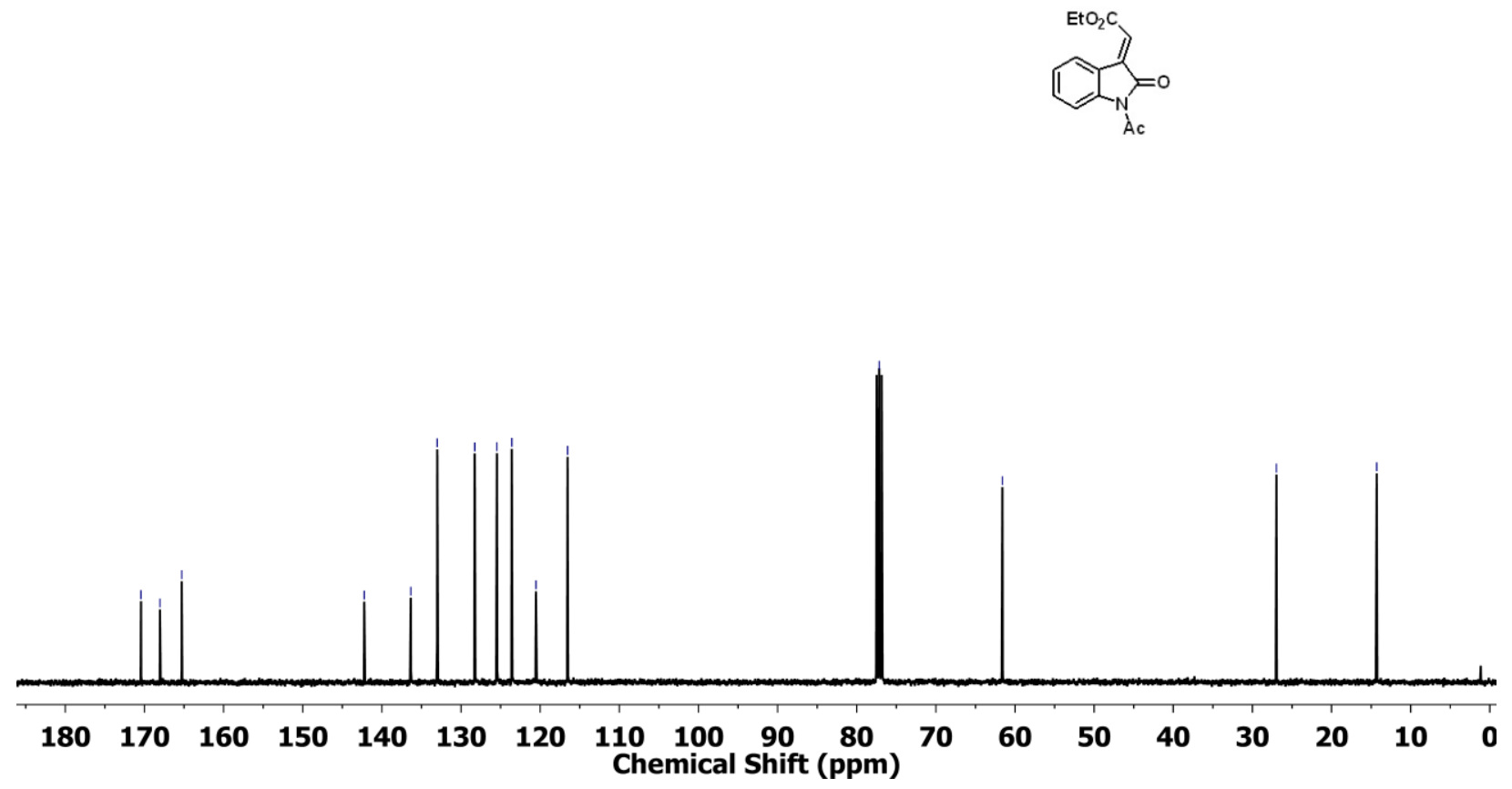
${ }^{1} \mathrm{H}(400 \mathrm{MHz})$ and ${ }^{13} \mathrm{C}\left\{{ }^{1} \mathrm{H}\right\}(100 \mathrm{MHz})$ NMR of $6 \mathrm{c}$ in $\mathrm{CDCl}_{3}$ :
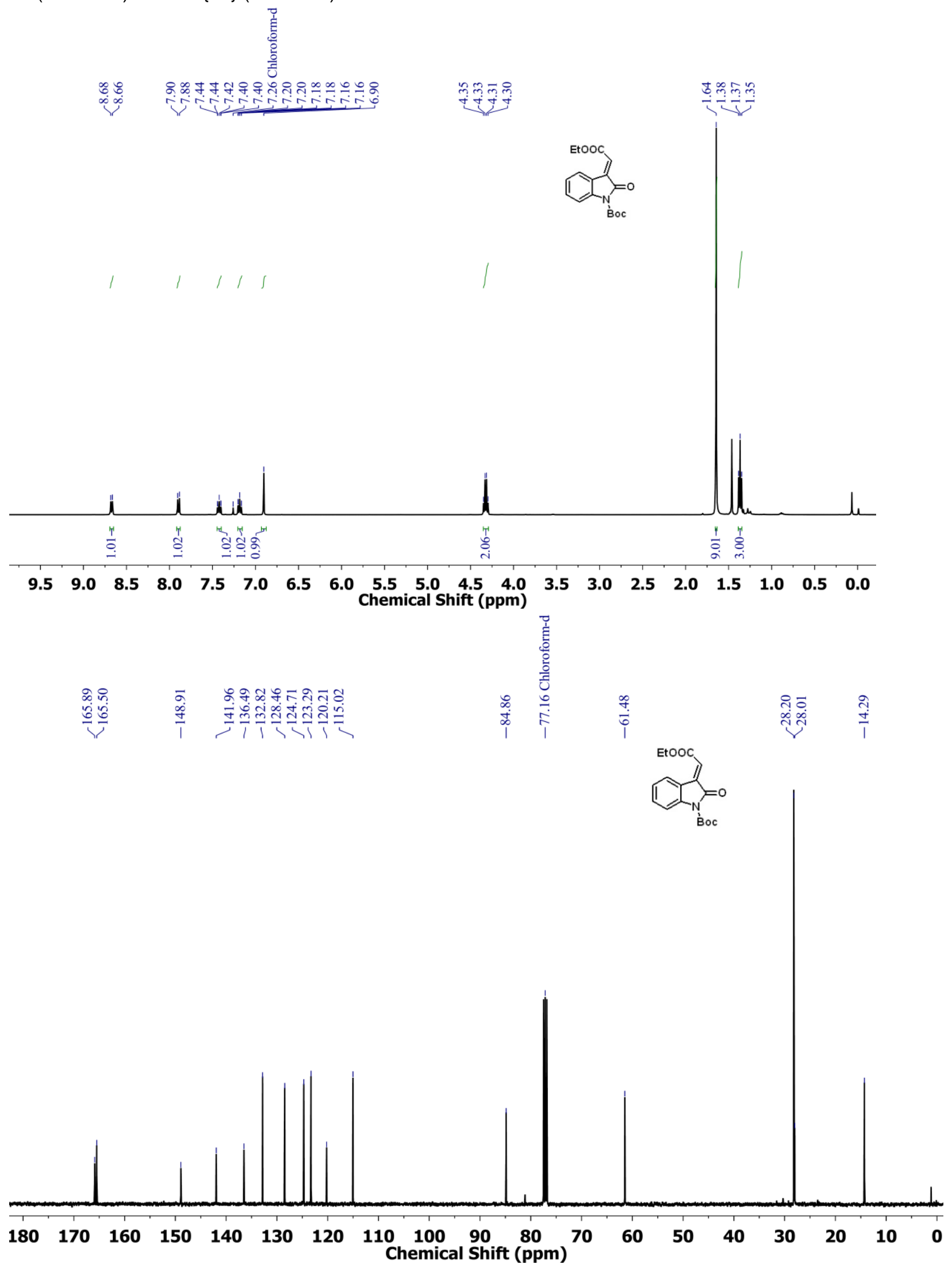